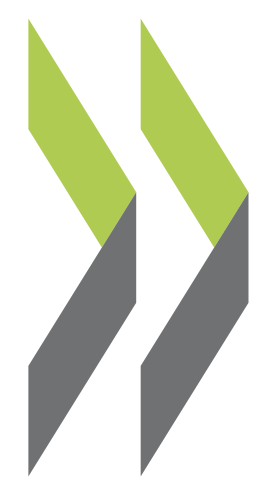

OECD Economics Department Working Papers No. 735

Prudential Regulation and Competition in Financial Markets

\section{Rudiger Ahrend,}

\section{Jens Matthias Arnold,}

Fabrice Murtin 
Organisation de Coopération et de Développement Économiques

Organisation for Economic Co-operation and Development

01-Dec-2009

ECONOMICS DEPARTMENT

English - Or. English

PRUDENTIAL REGULATION AND COMPETITION IN FINANCIAL MARKETS

ECONOMICS DEPARTMENT WORKING PAPER No. 735

by Rüdiger Ahrend, Jens Arnold and Fabrice Murtin

All OECD Economics Department Working Papers are available on the OECD Intranet website at www.oecd.org/eco/Workingpapers

JT03275443

Document complet disponible sur OLIS dans son format d'origine

Complete document available on OLIS in its original format 


\section{ABSTRACT / RÉSUMÉ}

\section{Prudential regulation and competition in financial markets}

This paper examines how a range of stability-oriented regulatory policies for banking and insurance are related to selected stability and competition outcomes in these sectors. Based on survey information on financial market regulation, policy indicators for eight areas of prudential banking regulation are constructed, in addition to indicators for the insurance sector. Despite incomplete information on some areas that turned out to be important in the context of the recent financial crisis, the indicators correlate well with different measures of financial stability, both during the recent crisis and beyond. Furthermore, the results do not support the view that there is a general trade-off between stability-oriented regulatory policies and competition in banking and insurance. Only few trade-offs are identified, with some areas of prudential regulation - most notably the strength of the banking supervisor - even associated with greater competition in banking. Overall, the results suggest that stability-enhancing regulatory reform does not necessarily come at the expense of competition. Although much of the analysis is based on pre-crisis regulatory settings which have been undergoing substantial change, the empirical evidence in this paper can provide useful insights in the context of ongoing financial regulatory reform.

JEL Codes: E44; G01; G14; G21; G22; G28; G38; L11

Keywords: Prudential regulation; banking; insurance; stability; competition

$* * * * * * * * * * * * * * * * * * * * * * * * * * * * * * * * * * *$

\section{Régulation prudentielle et concurrence sur les marchés financiers}

Cette étude examine le lien entre les politiques de régulation prudentielle des industries de la banque et de l'assurance et les résultats observés dans ces secteurs en termes de stabilité et de concurrence. Sur la base d'enquêtes portant sur la régulation des marchés financiers, des indicateurs sont construits pour évaluer les politiques touchant à huit segments différents de la régulation bancaire prudentielle, ainsi qu'au secteur de l'assurance. En dépit de lacunes dans le renseignement de certains segments de la régulation, lacunes préjudiciables dans le contexte récent de crise financière, ces indicateurs présentent une corrélation satisfaisante avec diverses mesures de stabilité financière, à la fois dans ce contexte de crise et au-delà. En outre, les résultats ne confirment pas l'hypothèse qu'il y aurait en général un arbitrage entre la régulation prudentielle et la concurrence dans les secteurs de la banque et de l'assurance. L'analyse permet d'identifier très peu d'exemples d'un tel arbitrage, et certains aspects de la régulation prudentielle, au premier desquels l'importance des pouvoirs conférés à l'autorité de régulation bancaire, sont au contraire associés avec plus de concurrence dans l'industrie bancaire. En somme, les résultats suggèrent que des réformes ayant comme objectif d'augmenter la stabilité des marchés financiers sont possibles sans porter préjudice à la concurrence. Bien que la plus grande partie de l'analyse utilise des données antérieures à la crise financière qui a entraîné de profonds changements, les relations empiriques identifiées dans cette étude fournissent un éclairage qui pourrait s'avérer utile pour les réformes à venir des politiques de régulation financière.

Codes JEL: E44 ; G01 ; G14 ; G21 ; G22 ; G28 ; G38 ; L11

Mots-clés: Régulation prudentielle; banque; assurance; stabilité; concurrence

\section{Copyright OECD 2009}

Application for permission to reproduce or translate all, or part of, this material should be made to: Head of Publications Service, OECD, 2 rue André-Pascal, 75775 Paris Cedex 16, France. 


\section{TABLE OF CONTENTS}

PRUDENTIAL REGULATION AND COMPETITION IN FINANCIAL MARKETS .................................5

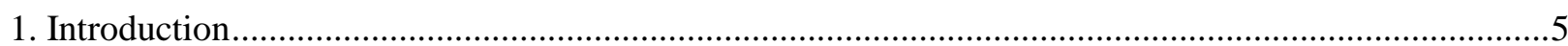

2. Measuring the stance of prudential regulations: Challenges and limitations in the construction of

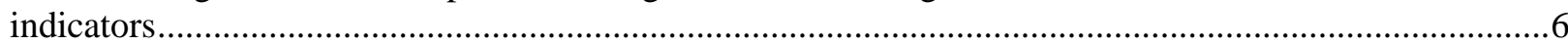

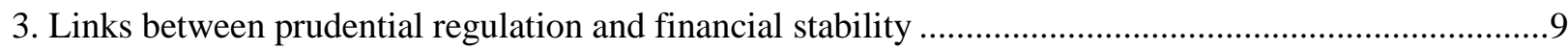

3.1 Links between prudential regulation and the financial crisis ........................................................ 10

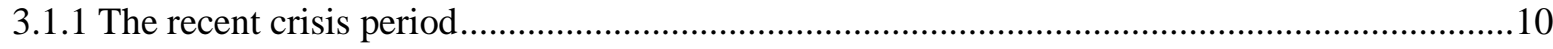

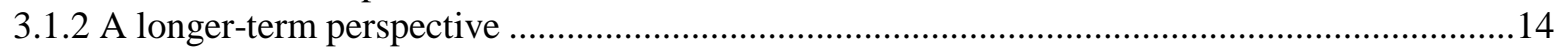

3.2 Links between prudential regulation and financial soundness indicators ......................................17

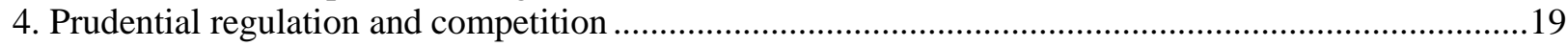

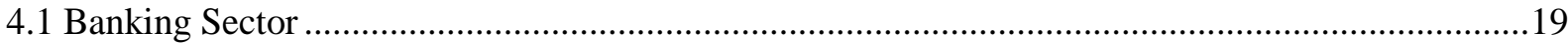

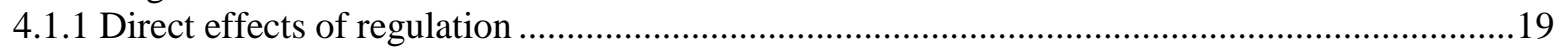

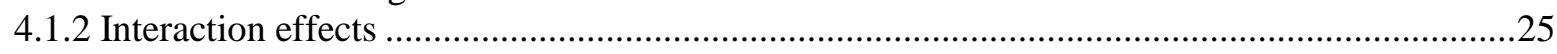

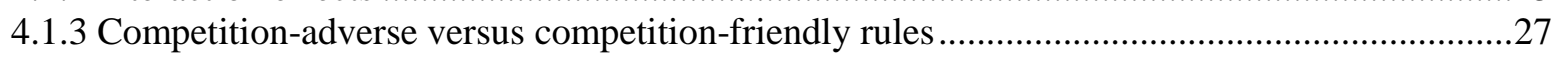

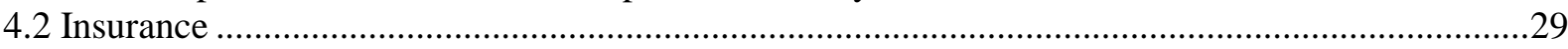

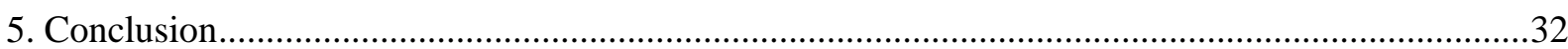

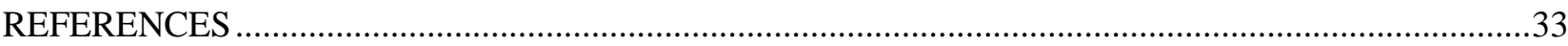

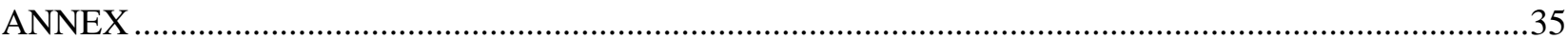

\section{Tables}

1. Prudential regulation and bank share prices during the recent crisis ................................................11

2. Prudential regulation and the fiscal cost of financial sector rescue packages .......................................13

3. Prudential regulation and bank share prices in the run-up towards the crisis ......................................15

4. Prudential regulation and bank share prices in a long-term perspective............................................16

5. Correlations between prudential banking regulation indicators and stability indicators ......................18

6. Correlations between prudential indicators and competition outcomes in banking..............................20

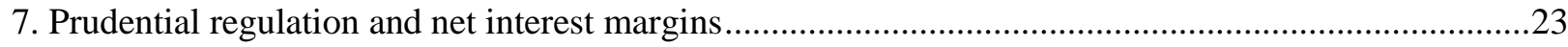

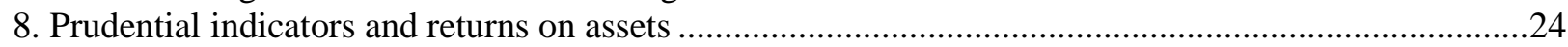

9. Prudential regulation and net interest margins in banking - Interactions I...................................26

10. Prudential regulation and net interest margins in banking - Interactions II ......................................27

11. Competition-friendly and competition-adverse prudential rules ....................................................29

12. Correlations between prudential regulation indicators and competition in insurance .........................30

13. Prudential insurance regulation and net underwriting margins ..........................................................

\section{Box}

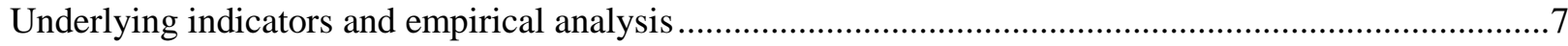

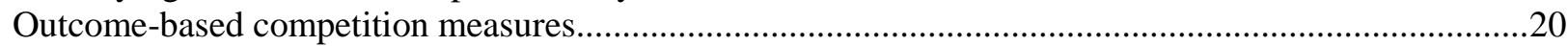


ECO/WKP(2009)76 
ECO/WKP(2009)76

\title{
PRUDENTIAL REGULATION AND COMPETITION IN FINANCIAL MARKETS
}

\author{
by \\ Rüdiger Ahrend, Jens Arnold and Fabrice Murtin ${ }^{1}$
}

\section{Introduction}

1. Competition in financial markets is likely to have a significant positive impact on growth, as suggested by both economic theory and empirical evidence. ${ }^{2}$ This underlines the importance for financial regulation not to curtail competition. At the same time, recent events have been a forceful reminder of the vital role of strong and well-designed prudential regulation for financial stability. The aim of this paper is to explore the relationship of financial sector regulation with both stability and competition outcomes, as well as possible trade-offs between these objectives. The analysis is mainly based on information pertaining to the period before the recent financial crisis. Even though financial regulation has been undergoing substantial change in response to the crisis, analysis based on pre-crisis regulation can still provide insights that - when properly weighed against other considerations - may turn out to be useful in current and future attempts to redesign the regulatory framework for financial markets.

2. Countries' regulatory stances are measured by policy indicators constructed from qualitative answers to questionnaires or qualitative assessments of compliance with standards of sound regulation, with all information pertaining to the period before the recent financial crisis. The indicators concerning banking regulation are based on an information set assembled by the World Bank and covering over 100 individual questions and assessments in different areas of prudential regulation. However, there are areas for which only insufficient or no comparable cross-country information is available. Some of these have featured prominently in the discussions following the recent crisis, such as off-balance-sheet exposures, accounting arbitrage, links between commercial and investment banking activities, incentives built into remuneration schemes, and macro-prudential regulation. Bearing these limitations in mind, based on the constructed indicators the regulatory stance in the considered areas of banking regulation shows significant variation both across and within countries.

3. The empirical analysis using these indicators then proceeds in two steps. In a first step, the prudential regulation indicators for banking are checked against measures of financial stability in the run-

1. The authors are indebted to Sven Blöndal, Adrian Blundell-Wignall, Romain Duval, Jørgen Elmeskov, André Laboul, Stephen Lumpkin, Sebastian Schich, Jean-Luc Schneider, Michael Tröge, delegates to the Working Party No. 1 on Macroeconomic and Structural Policy Analysis and to the Committee on Financial Markets and several members of the OECD Economics Department for useful comments, as well as to Caroline Abettan and Martine Levasseur for excellent editorial assistance. All remaining errors are those of the authors. The views expressed here are those of the authors, and do not necessarily reflect those of the OECD or its member countries.

2. See e.g. Serres et al. (2009), Jayaratne and Strahan (1996), or Stiroh and Strahan (2003). 
up to and during the financial crisis, and in a second step, their relation with measures of competition in the relevant financial market segments is explored.

4. The main findings are the following: The indicators of regulation prove to be relatively well correlated with the extent to which countries have eschewed harm during the current crisis, as measured either by the fiscal cost of financial sector rescue, or by the degree of equity value destruction in the banking sector. They are also correlated with available outcome-based measures of financial soundness in the banking sector. This suggests that the indicators contain useful information about the stance of prudential regulation, notwithstanding their partial nature. Regarding competition, and based on a range of less-than-perfect measures of the strength of competition in banking and insurance sectors, the analysis does not point to stronger prudential regulation having adverse effects on the strength of competition for either the banking and insurance sectors in general. Some areas of prudential regulation (most notably the strength of the banking supervisor) would even appear to be associated with greater competition in banking, possibly because strong supervision helps level the playing field across all competitors. Moreover, there are signs that different areas of prudential regulation seem to interact in how they affect competition in banking. For example, where supervisors are strong (weak), stricter capital requirements or a more credible threat of forced exit are found to go along with more (less) competitive banking industries. In a few specific areas, however, the analysis suggests a trade-off between the strength of prudential regulation and competition. In particular, tighter banking regulation with respect to entry rules and ownership structures appears to weaken competition.

5. The remainder of the paper is structured in the following way: Section 2 discusses methodological issues and problems encountered in the construction of the prudential indicators. Section 3 examines the link between the banking regulation indicators and a set of indicators of financial soundness, as well as with variables measuring the strength of the financial crisis across countries. Section 4 reports on the link between the indicators of prudential regulation and measures of competition in banking and insurance markets. A final section concludes. Additional detail on the construction of the indicators as well as robustness checks are provided in an Annex at the end of this paper.

\section{Measuring the stance of prudential regulations: Challenges and limitations in the construction of indicators}

6. Summing up complex policies through summary indicators inherently presents a number of challenges. These arise both in the process of collecting the relevant policy information to be used, and when transforming qualitative policy information into synthetic indicators. At each of these two stages, it is crucial to understand both the strengths and the limitations of the approach. The present section discusses data availability and methodological issues with respect to indicator construction, and flags some important caveats in both areas. Further details on the construction of the indicators, as well as details on regulation by country and area, are provided in the Annex.

7. Comparable cross-country and cross-time information on stability-oriented financial market policies is available from the World Bank and the International Monetary Fund. The World Bank has carried out periodic surveys of regulations for the banking sector, which constitute the most complete collection of regulatory information on banking that is currently in the public domain. ${ }^{3}$ The database of the

3. The World Bank surveys, which constitute the largest part of the underlying information set, were released in 2007, 2003 and 2001, and cover the periods 2005/2006, 2001/2002 and 1998/2000, respectively. The last update of the panel database was published in June 2008, and was subsequently verified and corrected by OECD member and accession candidate (AC) countries, thus improving the reliability of the available information. 
strength of regulation consists of information about specific regulations which can be grouped into eight broad areas for which indicators have been constructed for 40 countries (see Box 1 for a description of issues covered by these eight areas).

\section{Box 1. Underlying banking indicators}

Prudential regulation indicators have been constructed for eight thematic areas based on survey information collected by the World Bank. These areas cover inter alia the following issues (see Annex for a full list of questions):

Capital requirements include minimum capital to asset ratios, variations of capital to asset ratios according to individual banks' credit, market or operational risks, the application of simple leverage ratios, the acceptability of subordinated debt and of revaluation gains as capital.

Liquidity and diversification requirements include limits on exposures to single or related borrowers, limits on sectoral concentration of lending and liquidity reserves.

Accounting and provisioning requirements include information on accounting standards, definitions of nonperforming loans, disclosure of off-balance sheet items.

External auditing and information disclosure requirements include information on external auditing requirements and their disclosure to supervisors, the scope of legal action against auditors in the case of negligence and against directors in the case of erroneaous or misleading information.

Entry rules and ownership structures includes information on the granting procedure and requirements for entry licenses, disclosure of and limitations on the source of funds, limits to engagement in securities, insurance and real estate activities, foreign lending and ownership of nonfinancial voting shares.

Exit rules and disciplining devices include measures relating to the forced exit of banks, bankruptcy procedures for banks, and the powers of supervisors to override management decisions if the solvency of a bank is under threat.

Depositor protection includes information on the existence and limits of explicit deposit insurance protection systems, the collection of premia to such schemes, whether fees depend on banks' risk profiles and co-insurance provisions.

Strength of the supervisory authority include the budget and number of professional supervisors relative to the size of the sector, the number and frequency of onsite inspections, the ability of supervisors to change banks' internal organisation structures, the protection of the supervisory agency from political interference and the protection of individual agency staff from law suits by banks.

8. It is important to bear in mind that information in these eight areas reflects the de jure rather than de facto strength of rules and not how they are implemented, or how well a regulatory regime works in practice. ${ }^{4}$ Gaps between the stringency of rules and their enforcement or implementation may arise for a variety of reasons, including insufficient institutional capacity in administration or the legal sphere, or influences of particular interests on regulators. However, available information on the strength and independence of the supervisory institution is also taken into account, and may to some degree capture implementation issues.

9. These eight thematic areas cover core aspects of prudentially-oriented regulatory policies for the banking sector. However, there are other potentially important areas - some of which appear to have played a role in the recent financial crisis - for which no or only insufficient internationally comparable information is available. For example, the scope for regulatory arbitrage due to the introduction of Basel II capital adequacy rules is hard to evaluate and compare across countries, in particular with respect to off-

4. For a discussion of the application of quality regulation principles by financial regulators, as well as the role of discipline in terms of consultation, transparency, and impact assessment in the way financial regulations is being developed see Black and Jacobzone (2009). 


\section{ECO/WKP(2009)76}

balance sheet exposures of banks. ${ }^{5}$ Compliance with capital adequacy rules is sometimes further obscured by the application of banks' own internal risk ratings to certain assets and increased possibilities to move assets between the trading and investment accounts. Rules that limit banks' specialisation into particular products or types of lending, such as sub-prime mortgages, are also poorly documented, although limits to sectoral concentration in lending in general are covered by the World Bank data. Other areas that are not well covered by existing information are the incentives built into remuneration schemes and the rules governing the inter-linkages between different kinds of banking activities, including the risk to deposittaking institutions emanating from ownership ties with investment banking and securities activities. ${ }^{6}$ Finally, beyond the regulation of individual banks at the micro level, the need for macro-prudential regulation has been widely discussed recently, but regulatory differences across countries in this area are not well documented by existing databases. For example, measures to enhance provisioning in periods of asset price bubbles, so as to counteract some of the pro-cyclical features in Basel II rules, may well contribute to the stability of the financial sector as a whole, but unfortunately no consistent cross-country information is available on this issue.

10. The indicators have been constructed from the underlying data in a relatively simple manner. The World Bank survey data on banking regulation are aggregated by area of regulation, using for each of the eight areas all questions available for a sufficient number of countries. As a starting point, answers to simple qualitative questions (Yes/No) are - unless stated otherwise - coded as either 10 (the regulation is good from a prudential point of view) or 0 (the regulation is bad from a prudential point of view). For more complex questions, qualitative answers are ordered and matched to the 0 to 10 scale on a judgmental basis, typically in a linear way, with smaller scores reflecting more moderate regulation. In the aggregation process, a weight is given to each question (low $=1$, normal $=2$, high $=3$ ) which principally reflects the perceived importance of the question for prudential regulation in the respective area. Weights may also reflect data quality or be influenced by the desire to strike a balance between different issues within a sector. The exact coding of all the answers and indicators is given in the Annex.

11. In addition to the World Bank surveys, which cover only the banking sector, information on prudential regulation in insurance markets has been made available by the IMF in the context of the Financial Sector Assessment Program (FSAP). These reports assess a country's degree of compliance with a number of recommendations by international standard setting bodies about the regulatory regime or regulatory practice for banking, insurance and securities markets. ${ }^{7}$ For insurance, a regulation indicator has been constructed on the basis of FSA country reports. The FSAP reports cover issues such as the adequacy of the supervisory system, governance and prudential requirements for the supervised entity, as well as practices of ongoing insurance supervision. In contrast to the comprehensive country coverage of the World Bank survey data, complete FSAP information is not available for all OECD countries. ${ }^{8}$ The fact

5. The only information available on off-balance sheet items in the World Bank survey is a question on the requirements governing their disclosure.

6. Such ties might provide artificially cheap access to capital for higher-risk investment banking and securities activities, thus encouraging an overly large expansion of these areas.

7. For the banking sector, the FSAP reports contain considerably less detailed information than the World Bank surveys, lack a time series and cover only a subset of countries. Their inclusion into the banking indicators would therefore have meant a much reduced coverage and was not considered.

8. Notably, publicly available information for the United States is absent at present. As FSAP coverage of OECD accession candidate (AC) and enhanced engagement (EE5) countries is very incomplete, indices for insurance and securities markets are not compiled for those countries. AC countries are Chile, Estonia, Israel, Russia and Slovenia, while EE5 countries are Brazil, China, India, Indonesia and South Africa. 
that FSAP reports reflect regulatory stances in different base years ${ }^{9}$ and have been compiled by different teams is likely to have some implications for comparability across countries.

12. It is important to underline that the information based on FSAP reports is qualitatively different from the survey-based information for the banking sector: whereas survey information for banking refers to details on specific regulations, the FSAP information relies on the assessed degree of compliance with certain recommendations with respect to the regulatory framework or regulatory practices. Each compliance assessment aggregates a fairly large amount of information on the regulatory situation in a given field, while also incorporating a certain amount of judgement by the assessors. ${ }^{10}$ Compliance assessments are not direct measures of regulation but, nonetheless, may provide implicit measures of the strength of prudential regulation in a given financial sector. ${ }^{11}$

13. Constructing indicators of prudential regulation from the basic information also faces a challenge inherent in any indicator building exercise, namely the intrinsic difficulty of transforming qualitative into quantitative data. Choices have to be made regarding the appropriate coding of qualitative answers and assessments, and the appropriate weights to be applied in aggregating individual data points. While it would be ideal to know the "true" importance of each regulation when designing a weighting system, in reality such knowledge is unattainable. As a result, even statistically-based weighting structures always reflect to some degree subjective notions about the importance of different areas. The synthetic indicators presented in this paper are therefore subject to some uncertainty. At the same time, simulations show that such uncertainty is limited in practice, with the indicators proving quite robust to changes in weighting schemes. The indicators were also subjected to a number of additional robustness checks, which confirm that the ranking of countries for each of the eight indicators of banking regulation is fairly robust to missing data points. These robustness checks are presented in the Annex.

\section{Links between prudential regulation and financial stability}

14. If stability-oriented policies for the banking sector are effective, more stringent prudential banking regulation should lead to more stable banking systems. The recent financial crisis provides one obvious opportunity for assessing whether this holds in practice. ${ }^{12}$ One would expect that more strictly regulated banking systems fared relatively better during the recent crisis, ceteris paribus. This section therefore looks at the links between the banking prudential regulation (BPR) indices and measures of the

9. This paper uses FSAP reports published between 2001 and 2008 that usually refer to the situation in the preceding year.

10. While in the framework of an FSAP exercise the degree of compliance is assessed for each country, this assessment has only been published explicitly for a restricted number of countries. As confidentiality agreements prevent the IMF from sharing the non-published explicit ratings of compliance, for countries with no published compliance ratings, these ratings had to be compiled by OECD staff on the basis of information published in the FSAP reports.

11. Demirgüç-Kunt et al. (2006) show that compliance principles concerning information provision of banks are positively related with bank soundness, in the sense that countries that require banks to report regularly and accurately their financial data to regulators and market participants have sounder banks.

12. If data on prudential regulation were available for a longer time span, it would have been interesting to take into account additional crisis events beyond the recent financial crisis, but unfortunately no historical data are available. 
depth of the financial crisis, and also explores correlations between the indices and broader measures of financial soundness compiled by the IMF. ${ }^{13}$

\subsection{Links between prudential regulation and the financial crisis}

15. The financial crisis has exposed significant weaknesses in prudential regulation, both conceptually and with respect to implementation. Banks have been affected by the crisis in many different ways, but two features that are most likely to be remembered for some time are the massive destruction of banking equity value and the substantial amounts of public funds that governments have put up to banks' rescue. Countries differ significantly with respect to both the magnitude of share price declines of banks and the size of the rescue packages (see Annex), and the aim of this section is to investigate to what degree there is evidence of an empirical link between the severity of the crisis along these two dimensions and prudential regulation, as measured by the BPR indicators.

\subsubsection{The recent crisis period}

16. A first look at the data focuses on developments in share prices in the most acute crisis period. Between the first quarter of 2007 and the first quarter of 2009, many banking share prices collapsed, wiping out large amounts of equity wealth. Share prices of 322 individual major banks from 32 countries for which the BPR indicators have been constructed are compared with the indicators of prudential regulation. ${ }^{14}$ More specifically, the ratio of the share price value at the end of the first quarter of 2009 to its value two years earlier is regressed on the 2005/06 value of each of the eight BPR indicators in separate regressions. In addition, separate regressions are also run using three statistical measures derived from the eight area indicators, namely for each country the mean value of all eight indicators, their standard deviation (as a measure of the inconsistency of regulatory stances across different areas of regulation), and their minimum (testing for whether the weakest component of regulation may have been most relevant for stability outcomes). ${ }^{15}$ Changes in non-financial equities are used to control for country-level risk factors not specific to banking, and these changes are proxied by the country-specific Datastream share index for non-financial companies, expressed as a ratio in the same way as the dependent variable.

17. The results presented in Table 1 suggest that the pre-crisis stance in some areas of prudential regulation bears a significant relationship with the severity with which bank valuations in different countries have been subsequently affected by the crisis. ${ }^{16}$ Significant results are obtained for the indicators pertaining to entry and ownership rules (5), exit and disciplining rules (6) and the strength of the

13. Carrying out a similar exercise for the insurance and securities markets indicators is not feasible due to the lack of data on stability outcomes in these sectors.

14. Only banks that are included in the Datastream Banking Share Price Index DSBANKS for the respective country were retained, leading to a sample of 322 banks with sufficient data availability. Given that the BPR indices have no variation across individual banks within countries, robust standard errors are clustered at the country level in order to avoid an artificial reduction of the standard errors that would make it unduly easy to obtain statistically significant results (see Moulton, 1991).

15. These three statistical measures are based on normalised versions of the indicators: For a given area indicator, for each country the cross-country mean is subtracted from the indicator value, and the result is divided by the cross-country standard deviation. In this way, each normalised BPR index captures a relative difference from the OECD average that is expressed on a scale comparable across all eight regulatory dimensions.

16. The simple regression analysis presented is admittedly far from a full-fledged empirical model of share price developments and possibly fails to control for some determinants of bank share prices. For example, an additional variable that could have been added if sufficient information was available would be announcements of government rescue packages for banks. 
supervisor (8). ${ }^{17}$ The estimated positive coefficients suggest that countries with relatively tight prudential regulation in these areas suffered significantly smaller losses in bank share prices in the first quarter of 2009 , relative to their pre-crisis values (a positive coefficient means a higher remaining equity value). The same holds for the mean of the indicators, consistent with the notion that countries with tighter overall prudential regulation experienced smaller bank share price declines between 2007 and 2009. Taken at face value, the size of the estimated coefficient suggests that improving regulation from the level of a country with moderately low regulation at the $25^{\text {th }}$ percentile of the cross-country distribution to the level of a country with moderately high regulation at the $75^{\text {th }}$ percentile would have been associated with a $19 \%$ higher share value at the beginning of 2009 , relative to 2007 share prices. ${ }^{18}$

Table 1. Prudential regulation and bank share prices during the recent crisis

\begin{tabular}{|c|c|c|c|c|c|c|c|c|c|c|c|c|}
\hline $\begin{array}{l}\text { Prudential Indicator } \\
\end{array}$ & 1 & 2 & 3 & 4 & 5 & 6 & 7 & 8 & AVG & SD & MIN & All 3 \\
\hline Capital Requirements & $\begin{array}{r}0.01 \\
(0.03)\end{array}$ & & & & & & & & & & & \\
\hline $\begin{array}{l}\text { Liquidity/ Diversification } \\
\text { Requirements }\end{array}$ & & $\begin{array}{r}-0.01 \\
(0.02)\end{array}$ & & & & & & & & & & \\
\hline $\begin{array}{l}\text { Accounting/ Provisioning } \\
\text { Requirements }\end{array}$ & & & $\begin{array}{r}0.04 \\
(0.03)\end{array}$ & & & & & & & & & \\
\hline $\begin{array}{l}\text { Ext. Auditing/Information } \\
\text { Disclosure }\end{array}$ & & & & $\begin{array}{r}-0.02 \\
(0.02)\end{array}$ & & & & & & & & \\
\hline Entry/ Ownership & & & & & $\begin{array}{l}0.144^{* * *} \\
(0.04)\end{array}$ & & & & & & & $\begin{array}{l}0.10^{* *} \\
(0.04)\end{array}$ \\
\hline Exit/ Disciplining Rules & & & & & & $\begin{array}{l}0.05 \text { ** } \\
(0.02)\end{array}$ & & & & & & $\begin{array}{l}0.03 \text { ** } \\
(0.01)\end{array}$ \\
\hline Depositor Protection & & & & & & & $\begin{array}{r}0.02 \\
(0.02)\end{array}$ & & & & & \\
\hline Strength of Supervisor & & & & & & & & $\begin{array}{l}0.09 * \star \star \\
(0.03)\end{array}$ & & & & $\begin{array}{l}0.05 \text { ** } \\
(0.02)\end{array}$ \\
\hline Average of Area Indicators & & & & & & & & & 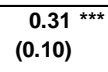 & & & \\
\hline $\begin{array}{l}\text { Standard Deviation of Area } \\
\text { Indicators }\end{array}$ & & & & & & & & & & $\begin{array}{r}-0.03 \\
(0.12)\end{array}$ & & \\
\hline Minimum of Area Indicators & & & & & & & & & & & $\begin{array}{r}0.05 \\
(0.06)\end{array}$ & \\
\hline $\begin{array}{l}\text { Share Price Development in } \\
\text { Non-Financials }\end{array}$ & $\begin{array}{l}0.62 \text { ** } \\
(0.27)\end{array}$ & $\begin{array}{l}0.77 \text { ** } \\
(0.29)\end{array}$ & $\begin{array}{l}0.70^{* *} \\
(0.26)\end{array}$ & $\begin{array}{l}0.70 * * * \\
(0.23)\end{array}$ & $\begin{array}{l}0.54^{* *} \\
(0.21)\end{array}$ & $\begin{array}{l}0.60 \text { ** } \\
(0.21)\end{array}$ & $\begin{array}{l}0.644^{\star *} \\
(0.27)\end{array}$ & $\begin{array}{l}0.82^{* * *} \\
(0.2)\end{array}$ & $\begin{array}{r}0.32 \\
(0.26)\end{array}$ & $\begin{array}{l}0.62 \text { ** } \\
(0.25)\end{array}$ & $\begin{array}{c}0.51 * \\
(0.27)\end{array}$ & $\begin{array}{l}0.64^{\star \star \star} \\
(0.19)\end{array}$ \\
\hline Observations & 322 & 322 & 322 & 322 & 322 & 322 & 322 & 322 & 322 & 322 & 322 & 322 \\
\hline R-squared & 0.06 & 0.07 & 0.09 & 0.07 & 0.20 & 0.13 & 0.07 & 0.15 & 0.17 & 0.06 & 0.08 & 0.24 \\
\hline
\end{tabular}

18. In order to check the robustness of these findings, two alternative specifications are estimated. First, all three indicators with a significant coefficient in individual regressions remain significant when entered simultaneously as explanatory variables in the estimated equation. This specification is presented in the last column of Table 1, and is consistent with the previous findings. Second, a simpler specification

17. Results are robust to using for each bank the overall amplitude of the share price swing, i.e. the distance between maximum and the minimum values instead of the value between early 2007 and 2009.

18. Based on the regression featuring as the main explanatory variable the average of the eight normalised indicators (see footnote 15). Across countries and for the most recent survey wave, the interquartile range of this average indicator is about 0.6 . 
is estimated, in which the indicators are replaced by dummy variables taking the value of 1 for countries in the lowest quartile with respect to each BPR indicator. ${ }^{19}$ The robustness checks confirm the previous findings for the areas of entry and ownership rules, exit and disciplining rules and the strength of the supervisor (see Annex for these results).

19. Beyond price declines in banking equity, another salient aspect of the recent financial crisis has been the high cost of bank rescue packages to taxpayers. Recent IMF work estimates the expected net cost of the support measures, taking into account the expected net cost of direct support to imperilled financial institutions, the expected costs of guarantees made by governments or central banks, and the expected cost of liquidity provisions. ${ }^{20}$ These estimates put the average cost across OECD countries at $4 \%$ of GDP, with estimated costs for Ireland, the United States and the United Kingdom reaching, 14, 13 and 9\% of GDP, respectively. The estimated size of rescue packages likely reflects not only the severity of the financial crisis, but also many other factors including inter alia the responsiveness of policy makers. Nonetheless, establishing a link between the indicators of prudential regulation and the fiscal cost of bank rescue packages would provide further suggestive evidence as to the importance of prudential regulation.

20. Applying the earlier econometric approach at the country (rather than individual bank) level, the estimated net fiscal cost is regressed on the 2005/06 value of each of the eight BPR indicators, as well as on the aforementioned statistical measures derived from these indicators (Table 2). ${ }^{21}$ Controls include a dummy variable for financial centres ${ }^{22}$ and a variable reflecting the monetary stance in the pre-crisis years. ${ }^{23}$

19. Insofar as measurement errors undermine the precision of the indicators, such binary variables may be seen as more reliable. Also, if there is a link between prudential regulation and banking equity losses in the data, then the lower end of the distribution of any given BPR indicator would be expected to have fared worse in this respect.

20. "Companion Paper - The State of Public Finances: Outlook and Medium-Term Policies after the 2008 Crisis", Table 4, IMF Fiscal Affairs Department, 2008. "Recovery rates", which critically influence the cost of direct interventions, are estimated based on historical data from former banking crises. Estimates of the expected cost of guarantees are broadly based on the Contingent Claims Approach (CCA), derived from modern finance theory.

21. Other specifications also examined as additional controls different measures of the size of the financial sector, as well as an indicator for the possibility of banks to engage in securities business. However, these turned out to be insignificant.

22. Global financial centres such as the United States, the United Kingdom and Switzerland could face a larger net cost. A possible explanation could be that particular interests have been especially strong in financial centres, resulting in regulatory indicators portraying an unduly strong regulatory stance. As such, this variable would pick up a bias in the indicators. Alternatively, governments with financial centres may be particularly willing to put up the resources to guarantee the survival of a strong financial sector. The use of a financial center dummy as a control variable improves the fit of the regression. However, the average of the area indicators, as well as the indicators for accounting and provisioning requirements and entry rules and ownership restrictions remain strongly significant even when omitting this control variable.

23. The degree to which imbalances (as bubbles in housing or credit markets) build up prior to a crisis may be thought to affect the strength of the crisis. During the recent pre-crisis period, a (downward) deviation from a Taylor rule, which under certain circumstances could be interpreted as overly accommodating monetary policy, has been associated with strong price increases in real estate, and concomitant developments of housing investment and mortgage credit (Ahrend et al. 2008). This may hence be expected to result in a larger need for financial sector bail-out, and consequently a larger net fiscal cost. The deviation of the short-term interest rate from the Taylor rate is calculated over the 2001q3-2006q4 period (for details see Ahrend et al. 2008). 
21. The econometric analysis lends support to the view that more stringent prudential financial regulation could have reduced the extent to which the financial sector has been hit by the crisis. Table 2 reports the results for separate regressions where the net cost of the crisis is, in turn, regressed on each of the eight banking indicators while controlling for the financial centre dummy, and the monetary policy variable ('difference from Taylor rule'). Three of the variables, namely the BPR indicators for capital requirements (1), accounting and provisioning requirements (4), and entry rules and ownership structures (6) are significantly (at the $1 \%$ confidence level) and negatively associated with the net expected cost of the financial crisis. ${ }^{24}$ At least for stronger prudential capital and provisioning requirements the results are not overly surprising, as both are intended to strengthen the capacity of financial institutions to remain stable in difficult situations. As newly entering banks typically would be expected to rely more on wholesale finance and less on deposits, more stringent entry rules may have led to a banking sector funded more heavily by deposits. It has been shown that banks with a larger share of deposits have shown a greater degree of resilience during the crisis (Ratnovski and Huang 2009), pointing to deposit shares being an important channel for the link between entry regulation and the strength of the crisis.

Table 2. Prudential regulation and the fiscal cost of financial sector rescue packages

\begin{tabular}{|c|c|c|c|c|c|c|c|c|c|c|c|c|}
\hline 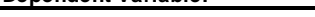 & & & & & & & & & & & & \\
\hline & 1 & 2 & 3 & 4 & 5 & 6 & 7 & 8 & AVG & SD & MIN & All 3 \\
\hline Capital Requirements & $\begin{array}{l}-1.16^{* \star \star} \\
(0.38)\end{array}$ & & & & & & & & & & & $\begin{array}{r}-0.49 \\
(0.37)\end{array}$ \\
\hline Low Capital Requirements & & & & & & & & & & & & \\
\hline $\begin{array}{l}\text { Liquidity and Diversification } \\
\text { Requirements }\end{array}$ & & $\begin{array}{r}0.74 \\
(0.43)\end{array}$ & & & & & & & & & & \\
\hline $\begin{array}{l}\text { Accounting and Provisioning } \\
\text { Requirements }\end{array}$ & & & $\begin{array}{l}-1.56^{* \star *} \\
(0.22)\end{array}$ & & & & & & & & & $\begin{array}{l}-1.05^{* \star \star} \\
(0.34)\end{array}$ \\
\hline $\begin{array}{l}\text { External Auditing and Information } \\
\text { Disclosure Requirements }\end{array}$ & & & & $\begin{array}{l}-0.68 \\
(0.45)\end{array}$ & & & & & & & & \\
\hline $\begin{array}{l}\text { Entry Rules and Ownership } \\
\text { Restrictions }\end{array}$ & & & & & $\begin{array}{l}-2.08^{* * *} \\
(0.50)\end{array}$ & & & & & & & $\begin{array}{l}-1.05^{*} \\
(0.51)\end{array}$ \\
\hline $\begin{array}{l}\text { Exit Rules and Disciplining } \\
\text { Devices }\end{array}$ & & & & & & $\begin{array}{l}-0.43 \\
(0.46)\end{array}$ & & & & & & \\
\hline Depositor Protection & & & & & & & $\begin{array}{r}-0.46 \\
(0.53)\end{array}$ & & & & & \\
\hline Strength of Supervisory Authority & & & & & & & & $\begin{array}{r}0.28 \\
(0.56) \\
\end{array}$ & & & & \\
\hline Average of Area Indicators & & & & & & & & & $\begin{array}{l}-5.91^{\star \star \star} \\
(1.17)^{2}\end{array}$ & & & \\
\hline $\begin{array}{l}\text { Standard Deviation of Area } \\
\text { Indicators }\end{array}$ & & & & & & & & & & $\begin{array}{l}6.25^{* *} \\
(2.29)\end{array}$ & & \\
\hline Minimum of Area Indicators & & & & & & & & & & & $\begin{array}{l}-2.82^{* \star \star} \\
(0.74)\end{array}$ & \\
\hline Financial Center Dummy & $\begin{array}{c}5.67^{*} \\
(3.13)\end{array}$ & $\begin{array}{r}4.35 \\
(2.68)\end{array}$ & $\begin{array}{l}3.99^{\star \star \star} \\
(1.09)\end{array}$ & $\begin{array}{r}4.06 \\
(2.47)\end{array}$ & $\begin{array}{c}4.899^{*} \\
(2.52)\end{array}$ & $\begin{array}{l}4.98 * \\
(2.51)\end{array}$ & $\begin{array}{r}3.95 \\
(2.88)\end{array}$ & $\begin{array}{r}4.22 \\
(2.77)\end{array}$ & $\begin{array}{l}5.57^{\star \star} \\
(1.92)\end{array}$ & $\begin{array}{r}3.05 \\
(1.85)\end{array}$ & $\begin{array}{l}4.03^{*} \\
(2.02)\end{array}$ & $\begin{array}{l}4.95^{\star \star \star} \\
(1.32)\end{array}$ \\
\hline $\begin{array}{l}\text { Downward deviation from Taylor } \\
\text { Rule }\end{array}$ & $\begin{array}{l}0.05^{* *} \\
(0.02)\end{array}$ & $\begin{array}{r}0.01 \\
(0.02)\end{array}$ & $\begin{array}{l}0.08^{* *} \\
(0.03)\end{array}$ & $\begin{array}{c}0.06 * \\
(0.03)\end{array}$ & $\begin{array}{l}0.05^{* *} \\
(0.02)\end{array}$ & $\begin{array}{c}0.06 * \\
(0.03)\end{array}$ & $\begin{array}{l}0.07^{\star *} \\
(0.03)\end{array}$ & $\begin{array}{c}0.06 \text { * } \\
(0.03)\end{array}$ & $\begin{array}{l}0.08^{\star \star \star \star} \\
(0.02)\end{array}$ & $\begin{array}{l}0.06^{* \star *} \\
(0.02)\end{array}$ & $\begin{array}{l}0.08^{* \star \star} \\
(0.02)\end{array}$ & $\begin{array}{l}0.06^{* \star *} \\
(0.02)\end{array}$ \\
\hline $\mathrm{R}^{2}$ & 0.49 & 0.38 & 0.74 & 0.4 & 0.67 & 0.38 & 0.4 & 0.35 & 0.65 & 0.55 & 0.6 & 0.77 \\
\hline $\mathrm{N}$ & 19 & $18^{24}$ & 19 & 19 & 19 & 19 & 19 & 19 & 19 & 19 & 19 & 19 \\
\hline
\end{tabular}

Note: Standard errors in brackets. ${ }^{* \star *},{ }^{\star \star},{ }^{*}$ indicate statistical significance at the 1,5 and $10 \%$ levels, respectively.

22. The average of the area indicators also turns out to be highly significant. Taken at face value, these findings would imply that the net fiscal costs of the crisis would be roughly $1.5 \%$ of GDP lower in a

24. Column 2 contains only 18 observations because one outlier country, Ireland, was dropped from this regression after sensitivity analysis. When including Ireland, which has both a strong regulatory stance in the area of liquidity and diversification requirements and has witnessed the highest net crisis cost among the countries in the sample, the index capturing liquidity and diversification requirements turns out to be positively associated with the net cost of the crisis, at a significance level of $10 \%$. 
country with moderately strong prudential regulation, compared with moderately weak regulatory settings. ${ }^{25}$ Furthermore, a smaller minimum value and wider heterogeneity ${ }^{26}$ of the area indicators are both associated with a substantially higher net fiscal cost. This hints at particularly weak regulation in one area and lack of consistency in the regulatory landscape having been factors that added to the cost of the crisis.

23. Including all the three significant area indicators of banking regulation at the same time does not alter the general picture. ${ }^{27}$ As shown in the last column of Table 2, two of them remain significant (accounting and provisioning requirements, as well as entry rules and ownership structures). While the capital requirements variable loses significance, a slightly more parsimonious specification using an indicator variable for the bottom quarter of the distribution of capital requirements remains significant and positive, indicating that countries with particularly low capital requirements suffered a significantly higher fiscal cost during the crisis. ${ }^{28}$

\subsubsection{A longer-term perspective}

24. Steep declines in banks' share prices during the recent crisis had often been preceded by spectacular share price increases in earlier years. With the benefit of hindsight, these increases may have partly reflected a financial bubble, with differences in price developments across countries possibly related to the stance of prudential regulation.

25. In order to explore this possibility, the earlier analysis is replicated over the 2002-07 period that corresponds to the run-up to the crisis (see Table 3) ${ }^{29}$ As before, share-price developments in non-financial sectors are controlled for and appear to be significant. Prudential regulations are found to matter in the area of exit and disciplining rules and, to a weaker extent, as regards the strength of the supervisory authority. In both cases, the estimated coefficient is negative, meaning that a stronger prudential stance has been associated with smaller share price increases pre-crisis. ${ }^{30}$

25. As before, this comparison is based on a definition of the $75^{\text {th }}$ percentile of the distribution for a country with "moderately high" average regulation and the $25^{\text {th }}$ percentile for "moderately low" regulation.

26. As measured by the standard deviation of the area indicators.

27. Countries such as Ireland, Netherlands and Sweden, where the cost of the crisis is expected to amount to respectively $13.9,8$ and $7.7 \%$ of GDP, mostly have below average regulatory indicators in those three regulatory areas (with the exception of accounting and provisioning requirements in Ireland which are close to OECD averages.)

28. This regression is not reported but results are available upon request.

29. Given the time period of interest for these regressions, the 2001 values of the BPR indicators have been used instead of the most recent values.

30. The estimated coefficients are significant at the $1 \%$ and at the $10 \%$ level, respectively. 
ECO/WKP(2009)76

Table 3. Prudential regulation and bank share prices in the run-up towards the crisis

Dependent Variable: Individual Bank Shares 2007q1 relative to 2002q1

\begin{tabular}{|c|c|c|c|c|c|c|c|c|c|c|c|}
\hline Prudential Indicator & 1 & 2 & 3 & 4 & 5 & 6 & 7 & 8 & AVG & SD & $\mathrm{MIN}$ \\
\hline Capital Requirements & $\begin{array}{l}0.13 \\
(0.1)\end{array}$ & & & & & & & & & & \\
\hline $\begin{array}{l}\text { Liquidity/ Diversification } \\
\text { Requirements }\end{array}$ & & $\begin{array}{l}-0.01 \\
(0.03)\end{array}$ & & & & & & & & & \\
\hline $\begin{array}{l}\text { Accounting/ Provisioning } \\
\text { Requirements }\end{array}$ & & & $\begin{array}{l}-0.01 \\
(0.09)\end{array}$ & & & & & & & & \\
\hline $\begin{array}{l}\text { Ext. Auditing/Information } \\
\text { Disclosure }\end{array}$ & & & & $\begin{array}{r}0.21 \\
(0.13)\end{array}$ & & & & & & & \\
\hline Entry/Ownership & & & & & $\begin{array}{r}-0.08 \\
(0.12)\end{array}$ & & & & & & \\
\hline Exit/ Disciplining Rules & & & & & & $\begin{array}{l}-0.15^{* * *} \\
(0.04)\end{array}$ & & & & & \\
\hline Depositor Protection & & & & & & & $\begin{array}{l}-0.06 \\
(0.08)\end{array}$ & & & & \\
\hline Strength of Supervisor & & & & & & & & $\begin{array}{l}-0.43 \text { * } \\
(0.24)\end{array}$ & & & \\
\hline Average of Area Indicators & & & & & & & & & $\begin{array}{l}-0.53 \\
(0.41)\end{array}$ & & \\
\hline $\begin{array}{l}\text { Standard Deviation of Area } \\
\text { Indicators }\end{array}$ & & & & & & & & & & $\begin{array}{l}-0.11 \\
(0.67)\end{array}$ & \\
\hline Minimum of Area Indicators & & & & & & & & & & & $\begin{array}{l}-0.46 \\
(0.33)\end{array}$ \\
\hline $\begin{array}{l}\text { Share Price Development in } \\
\text { Non-Financials }\end{array}$ & $\begin{array}{l}1.12^{* \star *} \\
(0.21)\end{array}$ & $\begin{array}{l}1.14^{* \star *} \\
(0.21)\end{array}$ & $\begin{array}{l}1.14^{* \star *} \\
(0.23)\end{array}$ & $\begin{array}{l}1.11^{\star \star *} \\
(0.21)\end{array}$ & $\begin{array}{l}1.16^{* \star *} \\
(0.23)\end{array}$ & $\begin{array}{l}1.10^{* \star *} \\
(0.2)\end{array}$ & $\begin{array}{l}1.09^{\star \star *} \\
(0.19)\end{array}$ & $\begin{array}{l}1.17^{\star \star *} \\
(0.26)\end{array}$ & $\begin{array}{l}1.18^{* * *} \\
(0.24)\end{array}$ & $\begin{array}{l}1.13^{\star \star \star} \\
(0.22)\end{array}$ & $\begin{array}{l}1.16^{* \star *} \\
(0.23)\end{array}$ \\
\hline Observations & 284 & 284 & 284 & 284 & 284 & 284 & 284 & 284 & 284 & 284 & 284 \\
\hline R-squared & 0.12 & 0.11 & 0.11 & 0.12 & 0.11 & 0.13 & 0.12 & 0.15 & 0.12 & 0.11 & 0.13 \\
\hline
\end{tabular}

26. To the extent that the strong share price increases in the banking sector in the years preceding the crisis had a "bubble" element, a combination of smaller pre-crisis price increases and lower subsequent declines might be indicative of a more stable banking system. However, less pronounced pre-crisis increases are clearly preferable only if they are associated with larger share price increases over the pre-crisis and crisis period taken together. A third set of regressions, using the 2005/06 vintage of BPR indicators, therefore considers as dependent variable the ratio of share prices at the end of the first quarter of 2009 to their value in 2002. ${ }^{31}$ The results presented in Table 4 suggest that the longer run reveals a positive link between share price developments and regulation. Accounting and provisioning requirements (3), entry and ownership requirements (5), as well as the average of the eight BPR indicators are positively and significantly related with the post-crisis level of banking equity prices relative to their value seven years earlier.

31. Alternatively, this analysis can be replicated using the most recent available observation, i.e. the third quarter of 2009, with very similar results. These results are available from the authors upon request. 
Table 4. Prudential regulation and bank share prices in a long-term perspective

\begin{tabular}{|c|c|c|c|c|c|c|c|c|c|c|c|}
\hline Prudential Indicator & 1 & 2 & 3 & 4 & 5 & 6 & 7 & 8 & AVG & SD & MIN \\
\hline Capital Requirements & $\begin{array}{r}0.00 \\
(0.08)\end{array}$ & & & & & & & & & & \\
\hline $\begin{array}{l}\text { Liquidity/ Diversification } \\
\text { Requirements }\end{array}$ & & $\begin{array}{r}-0.04 \\
(0.03)\end{array}$ & & & & & & & & & \\
\hline $\begin{array}{l}\text { Accounting/ Provisioning } \\
\text { Requirements }\end{array}$ & & & $\begin{array}{l}0.17^{\star *} \\
(0.07)\end{array}$ & & & & & & & & \\
\hline $\begin{array}{l}\text { Ext. Auditing/ Information } \\
\text { Disclosure }\end{array}$ & & & & $\begin{array}{r}-0.01 \\
(0.05)\end{array}$ & & & & & & & \\
\hline Entry/Ownership & & & & & $\begin{array}{l}0.19 * \\
(0.1)\end{array}$ & & & & & & \\
\hline Exit/ Disciplining Rules & & & & & & $\begin{array}{r}0.05 \\
(0.04)\end{array}$ & & & & & \\
\hline Depositor Protection & & & & & & & $\begin{array}{r}0.05 \\
(0.03)\end{array}$ & & & & \\
\hline Strength of Supervisor & & & & & & & & $\begin{array}{l}0.00 \\
(0.1)\end{array}$ & & & \\
\hline Average of Area Indicators & & & & & & & & & $\begin{array}{l}0.50^{*} \\
(0.29)\end{array}$ & & \\
\hline $\begin{array}{l}\text { Standard Deviation of Area } \\
\text { Indicators }\end{array}$ & & & & & & & & & & $\begin{array}{r}-0.12 \\
(0.23)\end{array}$ & \\
\hline Minimum of Area Indicators & & & & & & & & & & & $\begin{array}{r}0.10 \\
(0.12)\end{array}$ \\
\hline $\begin{array}{l}\text { Share Price Development } \\
\text { in Non-Financials }\end{array}$ & $\begin{array}{l}1.35^{* * *} \\
(0.3)\end{array}$ & $\begin{array}{l}1.41^{* * *} \\
(0.32)\end{array}$ & $\begin{array}{l}1.28^{* * *} \\
(0.25)\end{array}$ & $\begin{array}{l}1.36^{* * *} \\
(0.31)\end{array}$ & $\begin{array}{l}1.30^{\star \star \star} \\
(0.26)\end{array}$ & $\begin{array}{l}1.37^{\star \star *} \\
(0.3)\end{array}$ & $\begin{array}{l}1.36 \text { *** } \\
(0.29)\end{array}$ & $\begin{array}{l}1.35^{* \star *} \\
(0.3)\end{array}$ & $\begin{array}{l}1.24^{* * *} \\
(0.24)\end{array}$ & $\begin{array}{l}1.32^{\star * \star} \\
(0.3)\end{array}$ & $\begin{array}{l}1.28^{* \star *} \\
(0.28)\end{array}$ \\
\hline Observations & 284 & 284 & 284 & 284 & 284 & 284 & 284 & 284 & 284 & 284 & 284 \\
\hline R-squared & 0.34 & 0.34 & 0.36 & 0.34 & 0.35 & 0.34 & 0.34 & 0.34 & 0.35 & 0.34 & 0.34 \\
\hline
\end{tabular}

27. The empirical evidence seems to suggest that banks in countries with stronger prudential rules have been more stable and less severely affected by the financial crisis. Where banks were more strongly regulated, their share price increased less in the pre-crisis years, but also declined less during the current crisis, resulting in a net positive effect. The analysis suggests that ceteris paribus, a country with moderately strong average prudential regulation had about $30 \%$ more banking equity left in 2009 , relative to the 2002 value, compared with a country with moderately weak pre-crisis regulatory settings. ${ }^{32}$

28. Overall, the BPR indices constructed in this paper seem to partly explain differences in how strongly countries have been affected by the current crisis. However, many other factors have obviously played a role. Some countries managed to keep their banking sector largely out of trouble without particularly strong levels of prudential banking regulation, while, by contrast, some countries with relatively high levels of prudential regulation have been strongly affected by the financial crisis. This may point to the relevance of other, non-measured factors that can also be important ingredients in an effective prudential stance, and/or - in accordance with the empirical findings from the paper - reflect that some

32. Note that this figure relates to the 2002 levels of share prices, which was substantially below the 2007 level used as reference earlier. 
areas of prudential regulation were not decisive during the crisis. ${ }^{33}$ It may also be a sign of gaps between the regulatory regime and actual implementation.

29. The severe damage the current crisis has brought upon the financial sector of several countries may also be the reflection of a particular weakness on a relatively specific issue. Such a crucial weakness may have no or only little influence on indicator values, either because comparable data are unavailable, or because - by design - indicators capture a broad range of dimensions rather than a specific issue. As an example, for Iceland, which had significantly tightened prudential regulation prior to the crisis, the strong mismatch between the banking sector balance sheet (both in terms of size and currency composition) and the lender-of-last-resort capacities of the central bank probably played a key role in triggering the collapse of its financial system.

\subsection{Links between prudential regulation and financial soundness indicators}

30. In order to examine further whether beyond the recent financial crisis the BPR indices are related to stability outcomes, a set of indicators has been assembled from the "Financial Soundness Indicators" and the "Global Financial Stability Report" of the International Monetary Fund, and tested for correlations with the BPR indicators. With details on these cross-country correlations reported in Table 5 for both a narrow and a broad country sample, the following highlights a few of the most noteworthy correlations. It should be underlined that for some of the stability indicators (e.g. capital ratios) coverage or compilation methods may differ across countries, with the resulting "noise" in the stability indicators tending to undermine the statistical significance of the estimated correlation coefficients.

31. The main findings are the following: Stricter capital requirements are positively correlated with capital strength, as represented by the simple capital-to-assets ratio, ${ }^{34}$ while stronger liquidity and diversification requirements are weakly correlated with the share of liquid assets. The correlation between accounting and provisioning rules and both the ratio of provisions to total loans and the share of nonperforming loans is significantly positive. This would be consistent with the explanation that, under tighter regulation, the expected improvement in quality of the loan portfolio itself may in practice be dominated by a lower threshold definition of what constitutes a non-performing loan, and narrower possibilities for banks to classify non-performing loans as performing. ${ }^{35}$ Requiring banks to disclose more information is not significantly correlated with any of the financial soundness measures considered here, possibly reflecting that such regulations primarily aim to prevent fraud and strengthen corporate governance.

32. Both restrictions on entry and ownership of banks and stronger exit and disciplining rules are positively correlated with capital-to-assets ratios. The former correlation could reflect that new entrants are likely to be thinly capitalised, while the latter probably captures the fact that tougher exit rules both increase the exit of weakly capitalised banks and motivate remaining banks to hold larger capital cushions.

33. A possible example for an area where differences in the pre-crisis stance between countries had particularly little impact on the strength of the financial crisis is deposit insurance, not least because most countries extended it significantly in the very early stages of the crisis. At the same time, it may be no coincidence that the few depositor bank runs during this crisis occurred in countries with relatively low levels of precrisis depository protection.

34. While positive, the correlation with the ratio of regulatory capital to risk-weighted assets is insignificant. This may reflect the fact that stricter capital rules imply a tougher stance on the computation of regulatory capital or the risk weighting of assets, which may partly conceal the effect such rules should otherwise have on the incentives for banks to hold capital.

35. The lack of a significant correlation between accounting and provisioning rules and provisions as a share of non-performing loans would point to larger provisions as a share of total loans not coming from higher provisions for non-performing loans. 
Restrictions on entry and ownership of banks are also weakly correlated with higher customer deposit to total loans ratios. This could reflect that new entrants are - at least as long as they are developing a retail network - more likely to rely on wholesale funding. ${ }^{36}$ Finally, banks appear to make less use of financial derivatives, both on the asset and the liability side of the balance sheet, where exit and disciplining rules are more binding, and entry and ownership regulations are stronger.

Table 5. Correlations between banking prudential regulation Indicators and stability indicators

\begin{tabular}{|c|c|c|c|c|c|c|c|c|}
\hline OECD countries only & \multirow[b]{2}{*}{$\begin{array}{c}\text { Capital } \\
\text { requirements }\end{array}$} & \multirow[b]{2}{*}{$\begin{array}{l}\text { Liquidity and } \\
\text { Diversification } \\
\text { requirements }\end{array}$} & \multirow{2}{*}{$\begin{array}{c}\text { Accounting } \\
\text { and } \\
\text { Provisioning } \\
\text { requirements }\end{array}$} & \multirow{2}{*}{$\begin{array}{c}\text { External } \\
\text { auditing and } \\
\text { information } \\
\text { disclosure } \\
\end{array}$} & \multirow[b]{2}{*}{$\begin{array}{l}\text { Entry and } \\
\text { ow nership } \\
\text { regulations }\end{array}$} & \multirow[b]{2}{*}{$\begin{array}{c}\text { Exit and } \\
\text { disciplining } \\
\text { rules } \\
\end{array}$} & \multirow[b]{2}{*}{$\begin{array}{l}\text { Depositor } \\
\text { protection }\end{array}$} & \multirow[b]{2}{*}{$\begin{array}{c}\text { Strength o } \\
\text { the } \\
\text { supervisol }\end{array}$} \\
\hline Stability outcome indicators & & & & & & & & \\
\hline Regulatory Capital to Risk-Weighted Assets & 0.19 & 0.19 & 0.05 & 0.16 & -0.18 & $0.38^{* *}$ & 0.26 & -0.09 \\
\hline Capital to Assets & $0.40^{* *}$ & 0.05 & $0.46^{* *}$ & -0.07 & $0.48^{* *}$ & $0.58^{* \star *}$ & 0.15 & -0.15 \\
\hline Provisions to Nonperforming Loans & 0.28 & 0.06 & 0.17 & -0.16 & 0.16 & 0.28 & -0.17 & 0.05 \\
\hline Provisions to Total Loans & -0.02 & 0.23 & $0.51^{* * *}$ & 0.14 & 0.38 * & 0.17 & 0.24 & -0.19 \\
\hline Nonperforming Loans to Total Loans & -0.02 & 0.00 & 0.37 * & 0.03 & 0.22 & 0.01 & 0.26 & -0.18 \\
\hline Liquid Assets to Total Assets & -0.06 & 0.32 & -0.05 & 0.16 & -0.19 & -0.04 & -0.02 & 0.16 \\
\hline Gross Liability Position in Financial Derivatives to Capital & 0.16 & 0.13 & -0.33 & 0.18 & $-0.70^{* * *}$ & -0.37 & -0.08 & 0.20 \\
\hline Gross Asset Position in Financial Derivatives to Capital & 0.16 & 0.10 & -0.35 & 0.18 & $-0.71^{* * *}$ & -0.35 & -0.10 & 0.20 \\
\hline Customer Deposits to Total (non-interbank) Loans & -0.06 & 0.07 & 0.18 & -0.16 & 0.25 & 0.30 & 0.27 & 0.01 \\
\hline OECD + AC + EE5 countries & & & Accounting & External & & & & \\
\hline Stability outcome indicators & $\begin{array}{c}\text { Capital } \\
\text { requirements }\end{array}$ & $\begin{array}{l}\text { Liquidity and } \\
\text { Diversification } \\
\text { requirements } \\
\end{array}$ & $\begin{array}{c}\text { and } \\
\text { Provisioning } \\
\text { requirements }\end{array}$ & $\begin{array}{c}\text { auditing and } \\
\text { information } \\
\text { disclosure }\end{array}$ & $\begin{array}{l}\text { Entry and } \\
\text { ow nership } \\
\text { regulations }\end{array}$ & $\begin{array}{l}\text { Exit and } \\
\text { disciplining } \\
\text { rules }\end{array}$ & $\begin{array}{l}\text { Depositor } \\
\text { protection }\end{array}$ & $\begin{array}{c}\text { Strength of } \\
\text { the } \\
\text { supervisor }\end{array}$ \\
\hline Regulatory Capital to Risk-Weighted Assets & 0.17 & 0.18 & 0.12 & 0.06 & 0.00 & $0.37^{* *}$ & $0.28 *$ & -0.03 \\
\hline Capital to Assets & $0.44^{* *}$ & -0.08 & 0.40 ** & -0.24 & 0.44 ** & $0.57^{* * *}$ & 0.06 & -0.14 \\
\hline Provisions to Nonperforming Loans & 0.21 & 0.13 & 0.06 & -0.21 & 0.07 & 0.29 & -0.15 & -0.15 \\
\hline Provisions to Total Loans & 0.01 & 0.22 & 0.35 ** & 0.03 & $0.49^{* * *}$ & 0.24 & 0.31 * & 0.05 \\
\hline Nonperforming Loans to Total Loans & -0.04 & 0.07 & 0.36 ** & 0.06 & 0.39 ** & 0.10 & 0.32 * & 0.06 \\
\hline Liquid Assets to Total Assets & -0.11 & 0.30 * & -0.08 & 0.05 & -0.20 & -0.07 & 0.08 & 0.00 \\
\hline Gross Liability Position in Financial Derivatives to Capital & 0.16 & 0.08 & -0.27 & 0.13 & $-0.63^{* * *}$ & $-0.39 *$ & 0.00 & 0.16 \\
\hline Gross Asset Position in Financial Derivatives to Capital & 0.16 & 0.06 & -0.29 & 0.13 & $-0.64 * * *$ & $-0.38 *$ & -0.01 & 0.15 \\
\hline Customer Deposits to Total (non-interbank) Loans & -0.09 & 0.11 & 0.17 & 0.00 & 0.33 * & 0.28 & 0.21 & 0.10 \\
\hline
\end{tabular}

Note: ${ }^{* * *},{ }^{* *},{ }^{*}$ indicate statistical significance at the 1,5 and $10 \%$ levels, respectively.

36. Assuming that deposits are less elastic to the degree of competition than loans, a higher deposit to loan ratio could also result from a lower level of loans caused by insufficient competition. 


\section{Prudential regulation and competition}

33. Having established that aspects of stability-oriented regulation, as measured by the BPR indices, indeed appears to be associated with stability features of financial systems, the next question to be examined is whether or not stability objectives are in conflict with competition in banking and insurance markets. While the key objective of prudential regulation is to ensure financial stability, in the current reconstruction of financial frameworks, attention should not only focus on reacting to the significant shortcomings that contributed to the current crisis, but also on ensuring that the new system will be both stable and efficient. ${ }^{37}$ The strength of competition is likely to influence the efficiency of financial intermediation and the quality of financial products. ${ }^{38}$ Moreover, competition can play a role for the access of firms and households to financial services and external financing, which may have far-reaching consequences for the economy, including for overall economic growth. This section explores possible links and/or trade-offs between prudential regulation and competition in the banking and insurance sectors. ${ }^{39}$

\subsection{Banking Sector}

\subsubsection{Direct effects of regulation}

34. Relating policies to competition in the banking sector requires a measure of competition outcomes, the construction of which is not straightforward. While a number of different approaches have been suggested, no clear consensus about the best approach has emerged from the literature. Box 2 discusses these methods in more detail, including their potential drawbacks and their adequacy for the purposes of this paper. For the reasons outlined in that Box, the preferred measure used in this paper is net interest margins, but for completeness returns on assets and $\mathrm{H}$-values are also examined.

35. A first look at cross-country correlations between the prudential regulation indices and the three retained measures of competition outcomes reveals that the correlations are generally weak and not statistically significant (Table 6). Two exceptions are the indicators for entry and ownership restrictions and the strength of the supervisor, both of which are in particular significantly correlated with net interest margins. Given that higher net interest margins may be indicative of less competition, the former correlation would suggest the potential for entry and ownership rules to dampen competition in banking, while the latter correlation would be consistent with a competition-enhancing role of a stronger supervisor. Table 6 also presents correlations between the competition measures and three statistical measures derived

37. In the light of amplified concentration, as well as increasing public ownership and intervention in the financial industry in the context of the current financial turmoil, it is likely that competition will be one key area of future challenges for the sector.

38. See OECD(2009).

39. Policies that enhance competition can, in principle, also have a negative impact on the stability of the financial system. However, most of the previous empirical cross-country evidence would seem to suggest that it does not. Schaek et al. (2009) find a positive relationship between bank competition and banking system stability. Looking into the possible channels of this correlation, Schaek and Cihak (2007) document that bank capitalisation of European banks is higher in more competitive environments. Beck et al. (2006a, b) present preliminary evidence that banking systems with more restrictions on entry and conduct are more vulnerable to systemic banking distress. Surveying the existing empirical evidence, Beck (2008) argues that, even though theoretically the link between competition in financial markets and stability is ambiguous, and in spite of some conflicting empirical evidence, the literature mostly points to a positive relationship between competition and stability in the banking system. In particular, measures that reduce contestability, such as entry restrictions, would seem to undermine rather than to strengthen the stability of the banking sector. Note that the data do not allow a separate analysis of competition in different subsegments of the banking sector, e.g. mortgage markets, but only in the banking sector as a whole. 
from the eight area indicators. Among the statistical measures used, only the mean value of the indicators displays a negative correlation with returns on assets. Correlations of all indicators with the H-Index are generally not statistically significant.

Table 6. Correlations between prudential indicators and competition outcomes in banking

\begin{tabular}{|c|c|c|c|c|c|c|c|c|c|c|c|}
\hline \multirow[t]{2}{*}{ Correlations } & 1 & \multirow{2}{*}{$\begin{array}{c}\text { 2 } \\
\text { Liquidity/ } \\
\text { Diversification } \\
\text { Requirements }\end{array}$} & \multirow[b]{2}{*}{$\begin{array}{c}3 \\
\text { Accounting/ } \\
\text { Provisioning } \\
\text { Requirements }\end{array}$} & \multirow{2}{*}{$\begin{array}{c}4 \\
\text { Ext. Auditing/ } \\
\text { Information } \\
\text { Disclosure }\end{array}$} & \multirow{2}{*}{$\begin{array}{c}5 \\
\text { Entry/ } \\
\text { Ow nership }\end{array}$} & \multirow{2}{*}{$\begin{array}{c}6 \\
\text { Exit/ } \\
\text { Disciplining } \\
\text { Rules }\end{array}$} & \multirow[b]{2}{*}{$\begin{array}{c}7 \\
\text { Depositor } \\
\text { Protection }\end{array}$} & \multirow[b]{2}{*}{$\begin{array}{c}8 \\
\text { Strength of } \\
\text { Supervisor }\end{array}$} & \multicolumn{3}{|c|}{ Statistical Measures } \\
\hline & $\begin{array}{c}\text { Capital } \\
\text { Requirements }\end{array}$ & & & & & & & & $\begin{array}{l}\text { Mean Value of } \\
\text { Area Indicators }\end{array}$ & $\begin{array}{c}\text { Std. Dev. of } \\
\text { Area Indicators }\end{array}$ & $\begin{array}{l}\text { Minimum of } \\
\text { Area } \\
\text { Indicators }\end{array}$ \\
\hline Net Interest Margins & -0.27 & -0.12 & 0.11 & -0.28 & 0.53 *** & 0.32 & 0.17 & -0.36 * & -0.04 & 0.03 & 0.02 \\
\hline Returns on Assets & 0.09 & -0.30 & -0.02 & -0.05 & -0.21 & -0.24 & -0.12 & $-0.45^{\star \star}$ & -0.23 * & 0.05 & -0.16 \\
\hline H-Index & 0.12 & 0.00 & 0.04 & -0.08 & -0.04 & -0.07 & -0.10 & 0.17 & -0.04 & -0.26 & 0.22 \\
\hline
\end{tabular}

\section{Box 2. Outcome-based competition measures}

Given the lack of detailed information on prices and cost structures in banking, measuring the degree of competition in this sector is not straightforward. As a result, the literature has relied on indirect measures of competition, including measures of market structure such as concentration indices, measures based on the actual pricing behaviour of banks, or measures based on accounting data of banks.

Concentration measures, including the C5 index or the Herfindahl index ${ }^{1}$, contain information about the actual observed market structure, but not necessarily about the intensity of competitive pressure. ${ }^{2}$ Banks' actual competitive behaviour may be influenced by factors other than market structure, including consumers' ease of switching banks or the prospects of collusion between banks. Moreover, the industrial organisation literature has long emphasised that competitive pressure may emerge not only from existing competitors but also from the threat of entry (Baumol et al. 1982), and this may be particularly relevant for the banking industry. ${ }^{3}$ Concentration indices completely miss the entry aspect, and can hence at best be considered partial measures of competition. Another reason to be wary of national concentration indices in banking is that some OECD countries have banks focusing only on a particular region. In these cases, less concentration need not mean more competition because not all existing banks are active on the same geographic markets or compete for the same business.

As an alternative to concentration measures, attempts have been made to estimate the degree of competition in a structural model of industrial organisation, based on a methodology originally developed by Panzar and Rosse (1987). In this approach, the degree of competition in the banking system is inferred from the pricing behaviour of banks. In essence, the competition measure resulting from this approach, usually referred to as the $\mathrm{H}$-Index, quantifies the degree to which banks' revenues, determined by their output prices, react to changes in input prices, with a high degree of pass-through assumed to reflect greater competition. ${ }^{4}$ The literature has used a number of different estimation specifications, each resulting in different estimates of $\mathrm{H}$-indices with often low correlations between them (Bikker et al. 2006). There is no agreement on how the underlying equation should be specified and the $\mathrm{H}$-indices therefore provide only limited practical guidance. In light of the disagreement in the literature, the first principal component of the most commonly used estimates has been retained here. ${ }^{5}$ One theoretical drawback of the $\mathrm{H}$-index approach, however, is that in some market areas, banks may be in direct competition with foreign banks. In such cases, output prices may essentially be fixed, thus cutting the link between the prices of output and domestically sourced inputs without this being a sign of weak competition.

A third approach is to use measures that are directly calculated (rather than estimated) from bank accounting data. Since the financial intermediation role of banks is to direct savings into profitable investment projects, the margin between the interest rate banks pay for their funds (including deposits and other forms of borrowing) and the interest rate charged for loans can be interpreted as a measure of competition and efficiency (see Demirgüç-Kunt and Huizinga, 1999). Lower interest margins can be the result of lower rents and/or a more immediate passing on of cost reductions to clients, both indicating more intense competition among banks. Lower interest margins are also easy to interpret in that they have clearly positive welfare implications for savers and borrowers, and are directly related to the cost of borrowing for enterprises and households. Since net interest margins can be influenced by factors other than competition, it is necessary to control for a number of industry and country-specific characteristics before interpreting higher net interest margins as reflecting market power or operational inefficiency. ${ }^{6}$

Other accounting ratios that have been used in the literature to measure competitive pressures in banking include returns on assets, or returns on equity. If there are rents from market power, then profits will be higher, and this would 
be reflected in higher returns on assets and returns on equity. But these measures can be misleading because banks with higher equity ratios will, ceteris paribus, automatically have higher returns on assets and lower returns on equity. ${ }^{7}$ However, controlling for the equity ratio when using returns on assets in econometric analysis can mitigate the possible bias that might be introduced by this automatic relationship.

In the light of the previous discussion, it is not obvious which measure of competition should be used to explore the links between regulatory policy and competition in the banking industry. Matters are further complicated by the fact that the correlations between the different competition measures are neither consistent nor particularly strong, and that as mentioned several specifications of the $\mathrm{H}$-Index have been used in the literature. In the absence of a consensus in the literature regarding the right competition measure to use, a considerable advantage of using net interest margins is the fact that they are relatively uncontroversial, easy to interpret, and closely related to the cost of borrowing of enterprises and households. As a result, the main focus of the analysis in this paper is on the empirical link between net interest margins and regulation measures, but for completeness relationships with returns on assets and $\mathrm{H}$-values are also analysed. For OECD countries, information on net interest margins and returns on assets can be obtained from aggregated financial statements of the banking sector in the OECD Bank Profitability data base. Net interest margins are calculated as banks' net interest income divided by total assets, and returns to assets as banks' before-tax profits divided by total assets.

1. The $\mathrm{C} 5$ index is calculated as the joint market share of the five largest banks (measured by assets), whereas the Herfindahl index is the sum of squares of the market shares of all banks. The two measures are typically strongly correlated, with higher values representing more concentration. The literature provides no clear mapping from market structure to the intensity of competition, and has not reached a consensus on whether market structure determines competitive behaviour or is itself a function of other factors (Beck, 2008). See Claessens and Laeven (2004) or Beck (2008) for critical views on using these as measures of competition.

2. For example, Besanko and Thakor (1992) show how lower entry barriers can improve the efficiency of financial intermediation provided by banks.

3. In more concentrated banking markets, both the perceived prices of banking services and the incidence of credit rationing are lower, and the quality of the bank services are better than in fragmented markets with many small banks. Such a situation could arise in countries where weak banking competition allows inefficient banks to survive, whereas they are driven out in countries with more competitive banking markets.

4. Under perfect competition, any increase in input prices would be fully passed onto consumers in the form of higher output prices. In this case, the $\mathrm{H}$-index would take its maximum value of 1 . Under imperfect competition, input prices will not have a one-to-one influence on pricing, with $\mathrm{H}$-values between 0 and 1 for monopolistic competition and below zero for the extreme case of a monopoly.

5. The first principal component has been extracted from the six different specifications presented in Bikker et al. (2006), and the specification used by Claessens and Laeven (2004).

6. These include a bank's funding structure and, more generally, the degree of financial transformation it provides.

7. As concerns returns on assets, the problem could be mitigated by using returns before interest payments. This ratio is, however, not available from the data sources accessible for this study. Returns on assets and returns on equity potentially also depend on the importance of fee income relative to income from financial intermediation.

36. The obvious shortcoming of simple correlations such as those presented in Table 6 is that they cannot control for any other possible influences on measures of banking competition. Even if some elements of prudential regulation have an impact on competition, it may be only after controlling for a number of other cross-country differences that such links become visible. The literature provides some guidance about possible specifications for a more robust econometric analysis of net interest margins and returns on assets. Demirgüç-Kunt and Huizinga (1999) present a model of banks' net interest margins and returns on assets for 80 countries over eight consecutive years, which serves as a point of departure for the present analysis. ${ }^{40}$ In that paper, net interest margins and returns on assets are explained by a number of characteristics specific to a country's banking sector, and the macroeconomic environment. The present analysis adopts this setup as a baseline and adds the indicators of prudential regulation described above as additional explanatory variables, in order to explore the links between different areas of prudential regulation and competition outcomes.

40. Demirgüç-Kunt and Huizinga's analysis is based on bank-level data, which have not been available for this exercise. Instead, their empirical model was replicated on the basis of aggregated financial statements of the banking sector from the OECD Bank Profitability data base. 
37. The regression analysis is conducted on panel data, using information on prudential regulation from three different waves of the World Bank survey spanning the period 1998 to $2006 .{ }^{41}$ The panel analysis has the advantage that unobserved constant differences at the country level that might otherwise bias the estimation results can be accounted for by using country fixed effects, while time-specific effects can be controlled for using year fixed effects. This makes the analysis substantially more robust, because beyond the possible influence of some aspects of prudential regulation, there are likely to be other determinants of the strength of banking competition, not all of which are adequately captured by available control variables. And even if appropriate indicators could be found for all of these differences, the estimations would soon run out of degrees of freedom to include additional variables. Given the lack of available panel data on the H-Index, this measure could not be used in the panel regression analysis.

38. One caveat to bear in mind is that the analysis does not control for competition-relevant financial market regulation that is not stability-motivated, because appropriate indicators are not available. Only insofar as such regulation has been constant over time would it be controlled for by the included country fixed effects.

39. The basic estimation equation takes the following form:

$$
\text { competition_measure }_{i t}=\alpha_{0}+\alpha_{i} \cdot B_{i t}+\beta_{i} \cdot X_{i t}+\gamma_{i} \cdot D_{i}+\delta_{t} \cdot D_{t}+\varepsilon_{i t}
$$

where the subscript $\mathrm{i}$ indicates countries and $\mathrm{t}$ indicates years. The dependent variable competition_measure stands for either net interest margins or for return on assets, both of which are calculated as in Demirgüç-Kunt and Huizinga (1999). $B_{i t}$ are banking sector characteristics, while $X_{i t}$ are macroeconomic country-characteristics, and $D_{i}$ and $D_{t}$ are country and year fixed effects, respectively. Country fixed effects are included because both an ordinary least square (OLS) estimator and a random effects estimator are rejected by Breusch-Pagan and Hausman tests, respectively, and because it seems indeed plausible that there are relevant country-characteristics that are not observable in the data. $\varepsilon_{i t}$ is a white-noise error term.

40. A further econometric issue to consider is the possible presence of serial auto-correlation in the data. Wooldridge (2002) suggests an auto-correlation test for panel data, and this test suggests that firstorder auto-correlation may indeed be present in the data. As a result, an appropriate panel estimator has to be able to account for the presence of autocorrelation. The preferred specification is based on a PraisWinsten estimator with panel-corrected standard errors (PCSEs) allowing for heteroscedasticity and autocorrelation with a common auto-correlation process across panels. Beck and Katz (1995) have made the case that this estimator is the most suitable choice for the kind of data situation encountered here (22 panels with a short time dimension). As robustness checks, two alternative specifications have been estimated and produce the same results (see Annex for details).

41. Table 7 shows in each column the results obtained from augmenting the baseline model with one of the eight BPR indices, as well as with statistical measures derived from these indices. Not all areas of

41. The prudential regulation indicators are available for three waves 1998/99, 2002/03 and 2005/06, with gaps in between. One possible source of bias might come from the fact that not all questions have been asked or answered in all years. To make sure that this has no influence on the estimation results, and to ensure a high degree of homogeneity of the indicators across the three waves of the survey, only information based on the same set of questions has been used in the construction of the time-series indicators. Where the information underlying the BPR index pertained to two different years, the earlier one of the two was chosen. The other variables used in the regression have been used as 3-year moving averages, to smooth cyclical influences or year-specific idiosyncratic effects that might be present in the data. The panel regressions are estimated on a data set of 22 countries and 3 time periods (resulting in 65 observations). 
prudential regulation appear to be related to competition outcomes in banking, with five of the eight areas showing no significant link with net interest margins. Some of the indicators, however, appear to have a significant link with competition, including the indicator of entry and ownership restrictions, the indicator of exit and disciplining rules, and the index measuring the strength of the supervisory authority. These findings are consistent with the notion that stronger entry and ownership restrictions reduce competition in banking, while more stringent exit and disciplining rules, as well as stronger and more independent supervisory bodies can enhance competition. As regards the statistical measures, the standard deviation of the eight area indicators and their minimum value are significantly correlated with net interest margins. This may suggest that inconsistent levels of stringency across different areas of prudential regulation could hamper competition, possibly by creating an uneven playing field.

Table 7. Prudential regulation and net interest margins

\begin{tabular}{|c|c|c|c|c|c|c|c|c|c|c|c|}
\hline & 1 & 2 & 3 & 4 & 5 & 6 & 7 & 8 & $A V G$ & $\mathrm{SD}$ & MIN \\
\hline Capital Requirements & $\begin{array}{l}-0.02 \\
(0.01)\end{array}$ & & & & & & & & & & \\
\hline $\begin{array}{l}\text { Liquidity/ Diversification } \\
\text { Requirements }\end{array}$ & & $\begin{array}{r}0.00 \\
(0.00)\end{array}$ & & & & & & & & & \\
\hline $\begin{array}{l}\text { Accounting/ Provisioning } \\
\text { Requirements }\end{array}$ & & & $\begin{array}{r}-0.01 \\
(0.01)\end{array}$ & & & & & & & & \\
\hline $\begin{array}{l}\text { Ext. Auditing/Information } \\
\text { Disclosure }\end{array}$ & & & & $\begin{array}{r}0.06 \\
(0.06)\end{array}$ & & & & & & & \\
\hline Entry/Ownership & & & & & $\begin{array}{l}0.111^{\star \star \star} \\
(0.01)\end{array}$ & & & & & & \\
\hline Exit/ Disciplining Rules & & & & & & $\begin{array}{l}-0.04 \\
(0.01)\end{array}$ & & & & & \\
\hline Depositor Protection & & & & & & & $\begin{array}{r}0.00 \\
(0.01)\end{array}$ & & & & \\
\hline Strength of Supervisor & & & & & & & & $\begin{array}{l}-0.10^{* * *} \\
(0.02)\end{array}$ & & & \\
\hline $\begin{array}{l}\text { Normalised Statistical } \\
\text { Measures }\end{array}$ & & & & & & & & & $\begin{array}{r}-0.08 \\
(0.07)\end{array}$ & 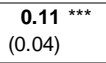 & $\begin{array}{l}-0.05^{\star \star *} \\
(0.01)\end{array}$ \\
\hline \multicolumn{12}{|l|}{ Bank-level control variables } \\
\hline Equity / lagged total assets & $\begin{array}{r}0.31 \\
(1.75)\end{array}$ & $\begin{array}{r}0.30 \\
(1.48)\end{array}$ & $\begin{array}{r}0.07 \\
(1.88)\end{array}$ & $\begin{array}{r}0.31 \\
(1.43)\end{array}$ & $\begin{array}{r}-0.02 \\
(1.19)\end{array}$ & $\begin{array}{r}1.32 \\
(1.61)\end{array}$ & $\begin{array}{r}0.24 \\
(1.60)\end{array}$ & $\begin{array}{r}0.28 \\
(1.80)\end{array}$ & $\begin{array}{r}0.30 \\
(1.64)\end{array}$ & $\begin{array}{r}0.31 \\
(1.45)\end{array}$ & $\begin{array}{r}0.23 \\
(1.52)\end{array}$ \\
\hline Loans / total assets & $\begin{array}{r}0.02 \\
(1.20)\end{array}$ & $\begin{array}{r}0.10 \\
(0.99)\end{array}$ & $\begin{array}{r}0.09 \\
(1.04)\end{array}$ & $\begin{array}{r}-0.35 \\
(1.42)\end{array}$ & $\begin{array}{r}0.38 \\
(0.73)\end{array}$ & $\begin{array}{r}-0.30 \\
(1.12)\end{array}$ & $\begin{array}{r}0.11 \\
(1.05)\end{array}$ & $\begin{array}{r}0.47 \\
(1.05)\end{array}$ & $\begin{array}{r}0.09 \\
(1.05)\end{array}$ & $\begin{array}{r}0.01 \\
(1.05)\end{array}$ & $\begin{array}{r}0.08 \\
(0.99)\end{array}$ \\
\hline $\begin{array}{l}\text { Non-interest earning assets/ } \\
\text { total assets }\end{array}$ & 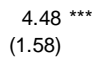 & $\begin{array}{l}4.86^{\text {***}} \\
(1.14)\end{array}$ & $\begin{array}{l}4.84^{\star \star *} \\
(1.13)\end{array}$ & $\begin{array}{l}4.69^{* \star *} \\
(1.70)\end{array}$ & $\begin{array}{r}3.34 \\
(2.55)\end{array}$ & $\begin{array}{l}3.40 \text { ** } \\
(1.67)\end{array}$ & $\begin{array}{l}4.96^{\star \star \star *} \\
(1.18)^{\circ}\end{array}$ & $\begin{array}{l}6.57^{\text {***}} \\
(0.75)\end{array}$ & $\begin{array}{l}4.82^{\text {*** }} \\
(0.93)\end{array}$ & $\begin{array}{l}4.36^{\text {***}} \\
(1.31)\end{array}$ & $\begin{array}{l}4.97^{\text {***}} \\
(0.94)\end{array}$ \\
\hline $\begin{array}{l}\text { Customer and short term } \\
\text { funding/ total assets }\end{array}$ & $\begin{array}{l}1.27^{\star \star \star} \\
(0.28)\end{array}$ & $\begin{array}{l}1.25^{* \star \star} \\
(0.29)\end{array}$ & $\begin{array}{l}1.26 \text { *** } \\
(0.31)\end{array}$ & $\begin{array}{l}1.68^{* \star *} \\
(0.21)\end{array}$ & $\begin{array}{l}1.62^{* \star *} \\
(0.19)\end{array}$ & $\begin{array}{l}1.20^{* \star *} \\
(0.28)\end{array}$ & $\begin{array}{l}1.23^{\star \star \star} \\
(0.19)\end{array}$ & $\begin{array}{l}1.61^{\star \star *} \\
(0.26)\end{array}$ & $\begin{array}{l}1.24^{* \star *} \\
(0.28)\end{array}$ & $\begin{array}{l}1.12^{\star * *} \\
(0.28)\end{array}$ & $\begin{array}{l}1.05^{* * *} \\
(0.21)\end{array}$ \\
\hline Overhead / total assets & $\begin{array}{l}1.41^{\star \star \star} \\
(0.35)\end{array}$ & $\begin{array}{l}2.10^{\star \star \star} \\
(0.26)\end{array}$ & $\begin{array}{l}1.96^{\star \star \star} \\
(0.52)\end{array}$ & 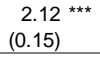 & $\begin{array}{r}1.06 \\
(1.58)\end{array}$ & $\begin{array}{l}1.59^{\star \star \star} \\
(0.52)\end{array}$ & $\begin{array}{l}2.16^{\text {***}} \\
(0.36)\end{array}$ & 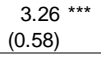 & $\begin{array}{l}1.93^{\star \star \star} \\
(0.67)\end{array}$ & $\begin{array}{l}1.80^{\star \star \star} \\
(0.42)\end{array}$ & $\begin{array}{l}1.83^{\star \star} \\
(0.84)\end{array}$ \\
\hline \multicolumn{12}{|c|}{ Macroeconomic Control Variables } \\
\hline GDP per capita & $\begin{array}{r}0.35 \\
(0.44)\end{array}$ & $\begin{array}{r}0.46 \\
(0.42)\end{array}$ & $\begin{array}{r}0.40 \\
(0.57)\end{array}$ & $\begin{array}{r}0.86 \\
(0.80)\end{array}$ & $\begin{array}{l}1.05^{* \star *} \\
(0.36)\end{array}$ & $\begin{array}{r}0.46 \\
(0.37)\end{array}$ & $\begin{array}{r}0.48 \\
(0.38)\end{array}$ & $\begin{array}{l}0.98 \text { ** } \\
(0.42)\end{array}$ & $\begin{array}{r}0.30 \\
(0.42)\end{array}$ & $\begin{array}{r}0.33 \\
(0.41)\end{array}$ & $\begin{array}{r}0.16 \\
(0.49)\end{array}$ \\
\hline Grow th rate & $\begin{array}{l}13.03^{\text {*** }} \\
(3.43)\end{array}$ & $\begin{array}{l}13.38^{* * *} \\
(3.54)\end{array}$ & $\begin{array}{l}13.34^{\text {*** }} \\
(3.45)\end{array}$ & $\begin{array}{l}13.91^{\text {***}} \\
(4.17)\end{array}$ & $\begin{array}{l}10.42^{\text {***}} \\
(2.03)\end{array}$ & $\begin{array}{l}13.05^{* \star *} \\
(2.88)\end{array}$ & $\begin{array}{l}13.21^{\text {***}} \\
(3.82)\end{array}$ & $\begin{array}{l}11.39 \text { *** } \\
(2.28)\end{array}$ & $\begin{array}{l}13.11^{\text {*** }} \\
(3.49)\end{array}$ & $\begin{array}{l}13.43^{\text {***}} \\
(3.68)\end{array}$ & $\begin{array}{l}13.27^{\star \star *} \\
(3.56)\end{array}$ \\
\hline Inflation rate & $\begin{array}{l}10.90^{\text {***}} \\
(4.22)\end{array}$ & $\begin{array}{l}10.46^{\text {***}} \\
(3.41)\end{array}$ & $\begin{array}{l}10.53^{\text {***}} \\
(3.31)\end{array}$ & $\begin{array}{l}11.91 \text { ** } \\
(4.84)\end{array}$ & $\begin{array}{l}7.60^{* \star *} \\
(2.41)\end{array}$ & $\begin{array}{l}10.51^{\text {***}} \\
(3.25)\end{array}$ & $\begin{array}{l}10.52^{\text {***}} \\
(3.18)\end{array}$ & $\begin{array}{l}8.99^{\text {***}} \\
(3.03)\end{array}$ & $\begin{array}{l}10.36 \text { *** } \\
(3.65)\end{array}$ & $\begin{array}{l}10.03^{\text {***}} \\
(3.04)\end{array}$ & $\begin{array}{l}10.02 \text { *** } \\
(3.37)\end{array}$ \\
\hline Real interest rate & $\begin{array}{r}0.00 \\
(0.02)\end{array}$ & $\begin{array}{r}0.01 \\
(0.02)\end{array}$ & $\begin{array}{r}0.01 \\
(0.02)\end{array}$ & $\begin{array}{r}0.01 \\
(0.02)\end{array}$ & $\begin{array}{r}0.03 \\
(0.02)\end{array}$ & $\begin{array}{r}0.01 \\
(0.02)\end{array}$ & $\begin{array}{r}0.01 \\
(0.02)\end{array}$ & $\begin{array}{r}0.02 \\
(0.02)\end{array}$ & $\begin{array}{r}0.01 \\
(0.02)\end{array}$ & $\begin{array}{r}0.01 \\
(0.02)\end{array}$ & $\begin{array}{r}0.00 \\
(0.02)\end{array}$ \\
\hline Country Fixed Effects & yes & yes & yes & yes & yes & yes & yes & yes & yes & yes & yes \\
\hline Year Fixed Effects & yes & yes & yes & yes & yes & yes & yes & yes & yes & yes & yes \\
\hline Observations & 65 & 65 & 65 & 65 & 65 & 65 & 65 & 65 & 65 & 65 & 65 \\
\hline R-squared & 0.88 & 0.87 & 0.88 & 0.88 & 0.89 & 0.88 & 0.87 & 0.89 & 0.78 & 0.78 & 0.78 \\
\hline
\end{tabular}

42. Table 8 replicates the same analysis using returns on assets rather than net interest margins as a dependent variable. Again, the regression results are consistent with entry and ownership restrictions hampering competition, while countries with stronger banking supervisors appear to have more competitive banking sectors. In addition to these results, stronger capital requirements, stronger liquidity and diversification rules as well as more stringent accounting and provisioning requirements are found to be associated with stronger competition as measured by returns on assets. A possible interpretation is that 
in these areas, applying uniformly high requirements on all banks may contribute to creating a sound environment that facilitates competition. ${ }^{42}$ Finally, higher depositor protection seems to be associated with lower competition. This finding could reflect that the depositor protection indicator contains information from a number of questions on public ownership in banking. ${ }^{43}$ While public ownership may enhance the security of depositors during crisis events because of implicit or explicit public guarantees, it may at the same time distort competition. The results on the statistical measures largely confirm the results obtained in the previous table with respect to the consistency of regulatory regimes and suggest that the average stringency of prudential regulation across different areas may actually enhance banking competition.

Table 8. Prudential indicators and returns on assets

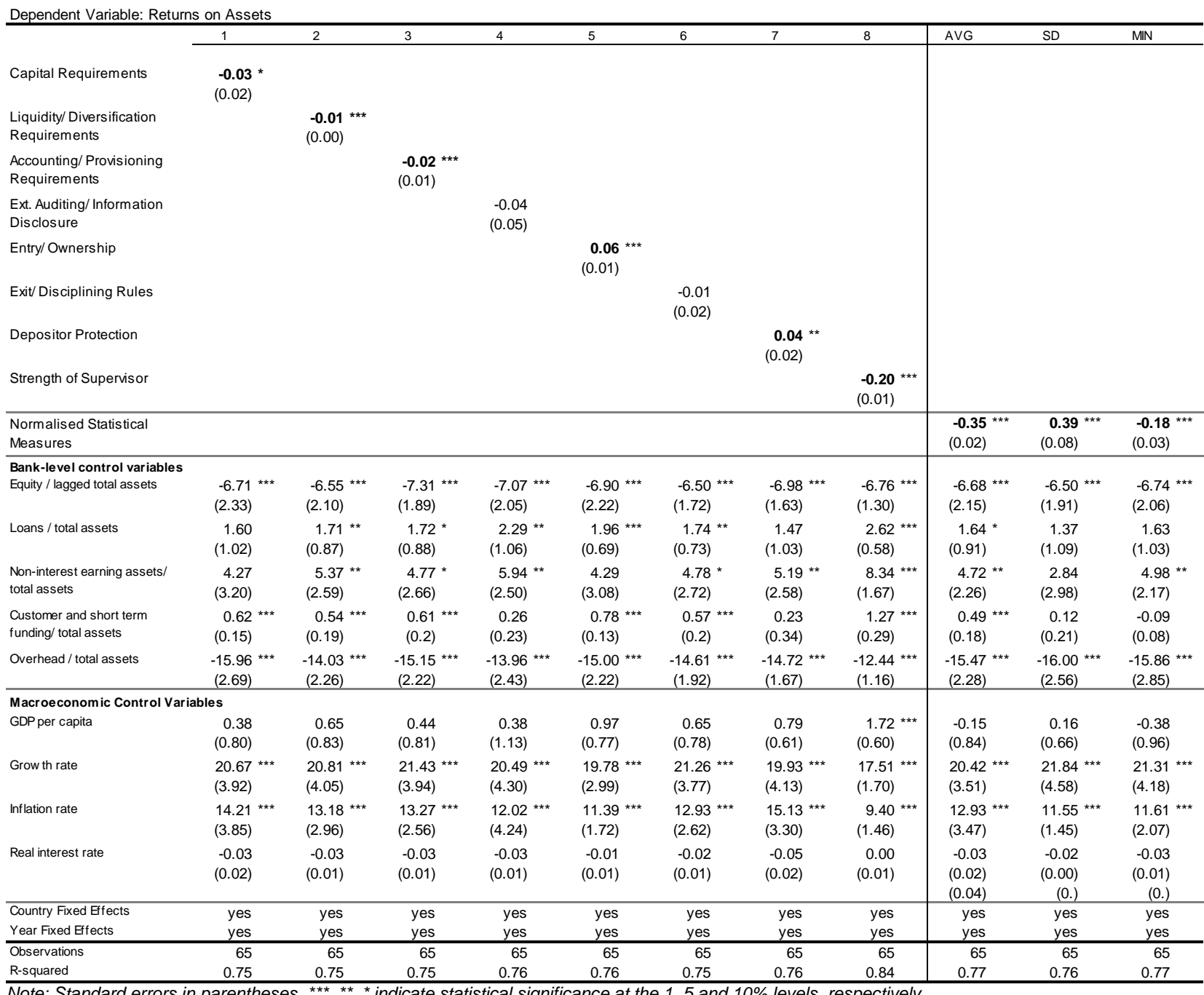

42. In the case of returns to assets, there may also be a direct effect from capital, liquidity and provisioning requirements on earnings, which need not be linked to competition.

43. See Annex for the list of questions on which the indicators are built. Alternatively, the finding could reflect that deposit insurance may increase the temptation for banks to engage in reckless risk-taking, driving up returns in normal times (but occasionally ending in bust). 
43. Taken together, the findings in Tables 7 and 8 do not support the idea that strong stabilityoriented regulation generally undermines competition and efficiency in the banking industry. Only a few specific regulatory measures - most robustly, entry and ownership restrictions - seem to be negatively related to indicators of banking competition, while the large majority of areas of prudential regulation seem not to interfere with banking competition or to even strengthen it.

\subsubsection{Interaction effects}

44. Different areas of prudential regulation may interact in how they affect competition in banking, i.e. the effect of one regulatory policy could depend on regulatory stances in other areas. To test for such possible interaction effects between different elements of the prudential toolbox, a number of interaction specifications have been attempted, focusing on net interest margins as the competition measure. While interactions are not relevant for all possible combinations of subject areas, a few significant interaction results emerge from interacting two indicators at a time. Both the indicator measuring the strength and independence of the supervisory authority, and the indicator measuring the requirements for external auditing and information disclosure seem to interact significantly with other areas of prudential regulation.

45. Table 9 presents a first set of interaction results, based on interactions with the indicator measuring the strength of the supervisor. On its own, this indicator displays a negative relationship with net interest margins, consistent with a beneficial effect on competition. When interacting the BPR indicator on capital requirements with the indicator on supervisory strength, it turns out that the effect of capital requirements depends strongly on the latter. Where supervisors are not particularly strong, capital requirements appear to hamper competition, possibly because - if not enforced properly - capital requirements can be abused to create an uneven playing field and distort competition. Given that capital requirements directly affect the costs of funding for banks, competition may be distorted if some banks find loopholes in those costly requirements. In contrast, where supervisors are strong, stricter capital requirements seem to go along with more competitive banking markets, and increasingly so the stronger the supervisory institution. The point where the effect switches signs appears to be somewhere around a median strength of the supervisory authority with respect to the present country sample. On the basis of these estimates, countries that are above-median with respect to the strength and independence of their supervisory authority, should expect a pro-competitive effect of stricter capital requirements, while this is not the case for countries with a low degree of supervisory strength. ${ }^{44}$

46. The strength of the supervisor also interacts with entry and ownership regulations, which display a negative link with competition when estimated without interaction. Although not statistically significant at all levels of the strength of supervisor, a closer look at the interaction reveals that the competitionadverse effect is declining in the strength of the supervisory institution, and is statistically significant across the sample except for the top $10 \%$ of countries with respect to supervisory strength. ${ }^{45}$ This finding may imply that a competition-adverse effect of entry and ownership rules can be mitigated if administered properly, but that such rules can easily be exploited to distort competition in weaker institutional environments.

47. Exit and disciplining rules, when entered into the regressions in interaction with the strength of the supervisor, appear to be more beneficial for competition the stronger the supervisory institution, and do actually not seem to matter for the lowest decile of supervisory independence in the sample. The potential

44. This more complex interaction effect with a switch in the direction of the correlation can explain why the indicator on capital requirement is not significant across the entire sample.

45. It becomes insignificant for the top 5\% of observations. However, the falling effect of entry and ownership rules in the context of strong supervisory institutions is estimated on the top end of the sample only and should therefore be interpreted with some caution. 
benefit of stronger discipline - from a competition perspective - may thus depend on a proper enforcement and implementation by sufficiently powerful and independent supervisory institutions.

Table 9. Prudential regulation and net interest margins in banking: Interactions with the strength of supervisor

\begin{tabular}{|c|c|c|c|c|c|c|}
\hline BPR Indicator & 1 & 2 & 3 & 4 & 5 & 6 \\
\hline Capital Requirements & $\begin{array}{l}-0.03 * * \\
(0.01)\end{array}$ & $\begin{array}{l}0.22 \text { *** } \\
(0.02)\end{array}$ & & & & \\
\hline $\begin{array}{l}\text { Above interacted } \\
\text { withStrength of Supervisor }\end{array}$ & & $\begin{array}{l}-0.04^{* * *} \\
(0.00)\end{array}$ & & & & \\
\hline Entry/ Ownership & & & $\begin{array}{l}0.10^{* * *} \\
(0.01)\end{array}$ & $\begin{array}{l}0.27^{*} \\
(0.16)\end{array}$ & & \\
\hline $\begin{array}{l}\text { Above interacted } \\
\text { withStrength of Supervisor }\end{array}$ & & & & $\begin{array}{r}-0.03 \\
(0.03)\end{array}$ & & \\
\hline Exit/ Disciplining Rules & & & & & $\begin{array}{l}-0.05^{* \star *} \\
(0.01)\end{array}$ & $\begin{array}{r}0.08 \\
(0.09)\end{array}$ \\
\hline $\begin{array}{l}\text { Above interacted } \\
\text { withStrength of Supervisor }\end{array}$ & & & & & & $\begin{array}{r}-0.02 \\
(0.01)\end{array}$ \\
\hline \multicolumn{7}{|c|}{ Combined effect of above BPR indicator at different levels of "Strength of Supervisor": } \\
\hline at 10th percentile & & $0.03 * * *$ & & $0.14^{* \star *}$ & & -0.03 \\
\hline at 25th percentile & & $0.02 * \star \star$ & & $0.13^{* * *}$ & & $-0.04^{* * \star}$ \\
\hline at 50th percentile (median) & & $-0.02 * \star *$ & & $0.10^{* * *}$ & & $-0.06^{* \star \star}$ \\
\hline at 75 th percentile & & $-0.06^{\star \star \star}$ & & $0.07^{\star \star \star *}$ & & $-0.08^{* \star \star}$ \\
\hline at 90th percentile & & $-0.08^{* * *}$ & & 0.07 * & & $-0.08^{* * *}$ \\
\hline Strength of Supervisor & $\begin{array}{l}-0.10^{* * *} \\
(0.02)\end{array}$ & $\begin{array}{l}0.08^{* * *} \\
(0.02)\end{array}$ & $\begin{array}{l}-0.08^{* * *} \\
(0.02)\end{array}$ & $\begin{array}{r}0.08 \\
(0.14)\end{array}$ & $\begin{array}{l}-0.11^{* * *} \\
(0.01)\end{array}$ & $\begin{array}{r}0.01 \\
(0.08)\end{array}$ \\
\hline \multicolumn{7}{|l|}{ Bank-level control variables } \\
\hline Equity / lagged total assets & $\begin{array}{r}0.47 \\
(2.04)\end{array}$ & $\begin{array}{r}0.79 \\
(1.87)\end{array}$ & $\begin{array}{r}0.05 \\
(1.26)\end{array}$ & $\begin{array}{r}0.75 \\
(1.82)\end{array}$ & $\begin{array}{r}1.93 \\
(1.57)\end{array}$ & $\begin{array}{r}2.57 \\
(1.91)\end{array}$ \\
\hline Loans / total assets & $\begin{array}{r}0.24 \\
(1.18)\end{array}$ & $\begin{array}{l}1.58 \text { * } \\
(0.88)\end{array}$ & $\begin{array}{r}0.64 \\
(0.77)\end{array}$ & $\begin{array}{r}0.56 \\
(0.80)\end{array}$ & $\begin{array}{l}-0.24 \\
(0.98)\end{array}$ & $\begin{array}{l}-0.21 \\
(1.00)\end{array}$ \\
\hline $\begin{array}{l}\text { Non-interest earning assets/ } \\
\text { total assets }\end{array}$ & $\begin{array}{l}5.73^{* * *} \\
(1.03)\end{array}$ & $\begin{array}{l}8.38^{* * *} \\
(0.83)\end{array}$ & $\begin{array}{l}4.89^{* * *} \\
(1.88)\end{array}$ & $\begin{array}{r}3.83 \\
(2.72)\end{array}$ & $\begin{array}{l}4.54^{* * *} \\
(0.76)\end{array}$ & $\begin{array}{l}3.66 \text { ** } \\
(1.45)\end{array}$ \\
\hline $\begin{array}{l}\text { Customer and short term } \\
\text { funding/ total assets }\end{array}$ & $\begin{array}{l}1.67^{* * *} \\
(0.27)\end{array}$ & $\begin{array}{l}1.37^{* * *} \\
(0.31)\end{array}$ & $\begin{array}{l}1.87^{* * *} \\
(0.19)\end{array}$ & $\begin{array}{l}2.09^{* * *} \\
(0.09)\end{array}$ & $\begin{array}{l}1.64^{\star \star \star} \\
(0.23)\end{array}$ & $\begin{array}{l}1.70 \\
(0.29)\end{array}$ \\
\hline Overhead / total assets & $\begin{array}{l}1.91^{* * *} \\
(0.15)\end{array}$ & $\begin{array}{l}6.02^{* * *} \\
(0.45) \\
\end{array}$ & $\begin{array}{r}2.03 \\
(1.34) \\
\end{array}$ & $\begin{array}{r}0.98 \\
(1.94) \\
\end{array}$ & $\begin{array}{l}2.55^{* \star \star} \\
(0.86)\end{array}$ & $\begin{array}{r}1.46 \\
(1.29) \\
\end{array}$ \\
\hline \multicolumn{7}{|c|}{ Macroeconomic Control Variables } \\
\hline GDP per capita & $\begin{array}{l}0.78 \text { * } \\
(0.44)\end{array}$ & $\begin{array}{r}0.65 \\
(0.42)\end{array}$ & $\begin{array}{l}1.40^{* \star *} \\
(0.31)\end{array}$ & $\begin{array}{l}1.14^{\star * *} \\
(0.23)\end{array}$ & $\begin{array}{l}0.98^{* * *} \\
(0.24)\end{array}$ & $\begin{array}{l}0.58 \text { * } \\
(0.34)\end{array}$ \\
\hline Grow th rate & $\begin{array}{l}10.87^{* * *} \\
(2.16)\end{array}$ & $\begin{array}{l}12.37^{\star * *} \\
(2.15)\end{array}$ & $\begin{array}{l}9.11^{* * *} \\
(1.30)\end{array}$ & $\begin{array}{l}9.02^{* * *} \\
(1.42)\end{array}$ & $\begin{array}{l}10.68^{* \star *} \\
(1.22)\end{array}$ & $\begin{array}{l}9.81 \\
(0.39)\end{array}$ \\
\hline Inflation rate & $\begin{array}{l}10.07^{* * *} \\
(3.77)\end{array}$ & $\begin{array}{l}9.15^{* * *} \\
(2.44)\end{array}$ & $\begin{array}{l}6.80^{* * *} \\
(2.33)\end{array}$ & $\begin{array}{l}5.46 \text { *** } \\
(1.49)\end{array}$ & $\begin{array}{l}9.80^{* * *} \\
(2.63)\end{array}$ & $\begin{array}{l}10.97^{* * \star} \\
(4.00)\end{array}$ \\
\hline Real interest rate & $\begin{array}{r}0.01 \\
(0.02)\end{array}$ & $\begin{array}{r}0.01 \\
(0.02)\end{array}$ & $\begin{array}{l}0.04^{* * *} \\
(0.02)\end{array}$ & $\begin{array}{l}0.05^{* * *} \\
(0.01)\end{array}$ & $\begin{array}{r}0.03 \\
(0.02)\end{array}$ & $\begin{array}{r}0.01 \\
(0.03)\end{array}$ \\
\hline Country Fixed Effects & yes & yes & yes & yes & yes & yes \\
\hline Year Fixed Effects & yes & yes & yes & yes & yes & yes \\
\hline Observations & 65 & 65 & 65 & 65 & 65 & 65 \\
\hline R-squared & 0.82 & 0.84 & 0.85 & 0.85 & 0.83 & 0.84 \\
\hline
\end{tabular}

48. A second set of interaction results, this time based on the BPR indicator on external auditing and information requirements, is presented in Table 10. Interacting this indicator with the one reflecting the strength of accounting and provisioning requirements suggests that the latter appear more competitionfriendly the more information banks have to disclose, and the stronger are the requirements for subjecting their accounts to external audits. In fact, where external auditing and information disclosure requirements 
are very low (in the bottom decile of the sample with respect to this indicator), stronger accounting and provisioning requirements seem to go along with higher interest margins. This relationship then switches sign and becomes statistically significant in the top quartile of the sample. In other words, stronger accounting and provisioning requirements seem to be associated with stronger competition among banks when combined with stringent rules on information disclosure and auditing.

Table 10. Prudential regulation and net interest margins in banking: Interactions with external auditing and information disclosure

\begin{tabular}{|c|c|c|}
\hline BPR Indicator & 1 & 2 \\
\hline Accounting and Provisioning Requirements & $\begin{array}{r}-0.01 \\
(0.01)\end{array}$ & $\begin{array}{l}0.222^{* * *} \\
(0.06)\end{array}$ \\
\hline $\begin{array}{l}\text { Above interacted with External Auditing and } \\
\text { Information Disclosure }\end{array}$ & & $\begin{array}{l}-0.03^{* * *} \\
(0.01)\end{array}$ \\
\hline $\begin{array}{l}\text { Combined effect of above BPR indicator at different } \\
\text { at } 10 \text { th percentile } \\
\text { at } 25 \text { th percentile } \\
\text { at } 50 \text { th percentile (median) } \\
\text { at } 75 \text { th percentile } \\
\text { at } 90 \text { th percentile }\end{array}$ & rnal Auditing & $\begin{array}{l}\text { Disclosure": } \\
0.05^{*} \\
0.02 \\
-0.01 \\
-0.02 * \star \\
-0.04 \text { ***}\end{array}$ \\
\hline External Auditing and Information Disclosure & $\begin{array}{r}0.06 \\
(0.06)\end{array}$ & $\begin{array}{l}0.22 \text { ** } \\
(0.09)\end{array}$ \\
\hline \multicolumn{3}{|l|}{ Bank-level control variables } \\
\hline Equity / lagged total assets & $\begin{array}{r}-0.11 \\
(1.43)\end{array}$ & $\begin{array}{r}1.63 \\
(1.29)\end{array}$ \\
\hline Loans / total assets & $\begin{array}{r}-0.53 \\
(1.45)\end{array}$ & $\begin{array}{r}-0.48 \\
(1.28)\end{array}$ \\
\hline Non-interest earning assets/ total assets & $\begin{array}{r}4.32 \\
(1.88)\end{array}$ & $\begin{array}{r}2.21 \\
(1.79)\end{array}$ \\
\hline Customer and short term funding/ total assets & $\begin{array}{l}1.76^{* * *} \\
(0.24)\end{array}$ & $\begin{array}{l}1.47^{* \star \star} \\
(0.23)^{2}\end{array}$ \\
\hline Overhead / total assets & $\begin{array}{l}1.57^{* * *} \\
(0.38)\end{array}$ & $\begin{array}{l}0.64 * \\
(0.37)\end{array}$ \\
\hline \multicolumn{3}{|l|}{ Macroeconomic Control Variables } \\
\hline GDP per capita & $\begin{array}{r}0.72 \\
(0.85)\end{array}$ & $\begin{array}{r}0.63 \\
(0.70)\end{array}$ \\
\hline Grow th rate & $\begin{array}{l}14.12^{\text {***}} \\
(4.17)\end{array}$ & $\begin{array}{l}13.45^{\text {*** }} \\
(3.64)\end{array}$ \\
\hline Inflation rate & $\begin{array}{l}12.55^{* * *} \\
(4.83)\end{array}$ & $\begin{array}{l}11.72^{* \star *} \\
(4.16)\end{array}$ \\
\hline Real interest rate & $\begin{array}{r}0.01 \\
(0.02)\end{array}$ & $\begin{array}{r}0.00 \\
(0.02)\end{array}$ \\
\hline Country Fixed Effects & yes & yes \\
\hline Year Fixed Effects & yes & yes \\
\hline Observations & 65 & 65 \\
\hline R-squared & 0.78 & 0.79 \\
\hline
\end{tabular}

\subsubsection{Competition-adverse versus competition-friendly rules}

49. The analysis has so far relied on grouping information on individual rules and regulations into eight areas of prudential policies and constructing indicators for each of those areas. While this approach allows for an easy interpretation of the constructed indices, the dividing line between rules that hamper competition and those that do not may run not only between, but also and perhaps primarily within these broad thematical areas. In order to explore this possibility, alternative BPR indices are constructed by classifying each individual rule according to its expected impact on competition from a theoretical, judgemental perspective. Concretely, individual rules are split into two groups: regulations that have the potential to distort and hamper competition (referred to as competition-adverse), and regulations that are 
either competition-neutral or competition-enhancing (referred to as competition-friendly). ${ }^{46}$ For example, regulations that could unduly prevent or complicate entry into banking or could distort a "level playing field" for banks would be classified as potentially competition-adverse, while rules that affect all incumbents and entrants alike would be labeled as competition-friendly. ${ }^{47}$ Relating such indicators to measures of competition allows getting a sense of whether prudential rules for which a competition impact seems theoretically plausible indeed affect competition in practice.

50. The first interesting observation is that the number of potentially competition-adverse regulations constitutes only a small share of the overall regulatory stance (see Annex). In fact, individual potentially competition-adverse rules were identified only in four of the eight regulatory areas described in Section 2, implying that for the other four, all regulations considered here are classified as "competition-friendly" (i.e. competition-neutral or competition-enhancing). ${ }^{48} \mathrm{~A}$ closer look reveals that potentially competitionadverse regulations are particularly concentrated in the area of entry and ownership restrictions.

51. Repeating the econometric analysis using indicators summarising these two broad classes of regulation shows that the indicator aggregating potentially competition-adverse regulations is associated with significantly less competition, while a higher value of the indicator aggregating the remaining regulations is actually associated with stronger competition outcomes (see Table 11). ${ }^{49}$ The latter may be a reflection of many prudential regulations contributing to level the playing field for all competitors in the banking sector. These results lends further support to the view that there is no general trade-off between stability and competition, but rather that the competition-adverse elements of stability-oriented policies are concentrated in a few areas and that it may be feasible to identify them.

46. While it is generally straightforward to detect regulations that may be potentially competition adverse (for example by restricting entry), it is often quite difficult to determine whether a regulation has no impact on competition, or may actually be competition enhancing. As the latter split is immaterial for the questions examined here, grouping the competition-neutral and competition-enhancing regulations together avoids the potential problem.

47. The classification into competition-friendly and competition-adverse regulations is made at the individual survey question level and regardless of the area those questions belong to.

48. These are the indicators with respect to capital requirements, accounting and provisioning requirements, exit rules and disciplining devices, as well as the strength of the supervisor.

49. These results hold for both measures of banking competition used. 
ECO/WKP(2009)76

Table 11. Competition-friendly and competition-adverse prudential rules

\begin{tabular}{|c|c|c|}
\hline Dependent Variable: & NIM & $\mathrm{ROA}$ \\
\hline $\begin{array}{l}\text { Competition-friendly prudential regulations from all } \\
\text { areas }\end{array}$ & $\begin{array}{l}-0.08^{* * *} \\
(0.00)\end{array}$ & $\begin{array}{l}-0.21^{\star * *} \\
(0.01)\end{array}$ \\
\hline $\begin{array}{l}\text { Competition-adverse prudential regulations from all } \\
\text { areas }\end{array}$ & $\begin{array}{l}0.06^{* * *} \\
(0.01)\end{array}$ & $\begin{array}{l}0.08^{* * *} \\
(0.00)\end{array}$ \\
\hline Equity / lagged total assets & $\begin{array}{r}1.40 \\
(0.91)\end{array}$ & $\begin{array}{r}2.20 \\
(0.00)\end{array}$ \\
\hline Loans / total assets & $\begin{array}{r}1.00 \\
(0.86)\end{array}$ & $\begin{array}{r}0.71 \\
(0.02)\end{array}$ \\
\hline Non-interest earning assets/total assets & $\begin{array}{r}1.25 \\
(0.00)\end{array}$ & $\begin{array}{r}2.60 \\
(0.01)\end{array}$ \\
\hline Customer and short term funding/ total assets & $\begin{array}{r}0.21 \\
(0.00)\end{array}$ & $\begin{array}{l}0.07^{* * *} \\
(0.00)\end{array}$ \\
\hline Overhead / total assets & $\begin{array}{r}1.02 \\
(0.03)\end{array}$ & $\begin{array}{l}1.17^{*} \\
(0.00)\end{array}$ \\
\hline GDP per capita & $\begin{array}{r}0.35 \\
(0.38)\end{array}$ & $\begin{array}{r}0.63 \\
(0.88)\end{array}$ \\
\hline Growth rate & $\begin{array}{r}2.51 \\
(0.00)\end{array}$ & $\begin{array}{r}2.78 \\
(0.00)\end{array}$ \\
\hline Inflation rate & $\begin{array}{l}3.55^{* *} \\
(0.00)\end{array}$ & $\begin{array}{l}3.05^{* \star \star} \\
(0.00)\end{array}$ \\
\hline Real interest rate & $\begin{array}{l}0.02^{* * *} \\
(0.42)\end{array}$ & $\begin{array}{l}0.01^{* * *} \\
(0.43)\end{array}$ \\
\hline $\begin{array}{l}\text { Country Fixed Effects } \\
\text { Year Fixed Effects }\end{array}$ & $\begin{array}{l}\text { yes } \\
\text { yes }\end{array}$ & $\begin{array}{l}\text { yes } \\
\text { yes }\end{array}$ \\
\hline Observations & 65 & 65 \\
\hline R-squared & 0.78 & 0.78 \\
\hline
\end{tabular}

\subsection{Insurance}

52. This final section looks at the link between the strength of prudential regulation and supervision of the insurance sector and competition in the insurance market. The insurance prudential regulation (INPR) index measures compliance with Insurance Core Principles issued by the International Association of Insurance Supervisors (IAIS), and as assessed in FSAP reports published by the IMF. The IAIS principles deal with the quality of insurance sector regulation and supervision in five main areas: resources and powers of the supervisor; licensing and corporate governance requirements; the extent of actual ongoing supervision; prudential capital requirements; and market practices surveillance. Sub-indices for these five areas are constructed, as well as summary indicators defined as the simple average of scores on each individual rule.

53. The analysis focuses on a particular outcome-based competition measure, net underwriting margins. This measure, defined as total premiums collected by insurers minus the claims paid to policyholders, divided by total premiums collected, is the equivalent of the preferred variable for measuring competition in the banking section. ${ }^{50}$ Focusing the analysis on this measure of competition reflects mainly data availability, but also that $\mathrm{H}$-statistics are particularly problematic for insurance where costs, i.e. future claims, are not fully observable (because they can be spread over a long period of time). Data on total premiums, gross claims (gross of reinsured policies), as well as on gross operating expenses are taken from the 2008 OECD Insurance Statistics. Starting in 2001, countries' net underwriting margins are calculated

50. Net interest margins, i.e. the difference between the interest rate banks pay on deposits and that charged for loans. 
for years with data on both premiums and claims available. As separate data for life and non-life insurance sectors are available, net underwriting margins are also calculated separately for these two sub-sectors. Life and non-life insurance are very different in nature, with life insurance often fulfilling functions of an investment fund rather than proper insurance functions.

54. Looking at simple correlations there is some evidence that a stricter regulatory and supervisory framework is associated with more competition in the insurance sector. The overall INPR index is negatively correlated with the net underwriting margin for the life-insurance sector (Table 12). In addition, a more detailed examination shows that four of the five sub-area indices of insurance regulation display a similarly significant negative correlation with the net underwriting margin, while the index measuring the strength of ongoing supervision is not significantly correlated with competition outcomes. This latter subindex aggregates the actual practice of the supervisor with respect to off-site monitoring, on-site inspections, preventive and corrective measures, enforcement of sanctions, procedures for insolvency, and group-wide supervision. Table 12 shows the correlations separately for this sub-index, while in light of their very similar statistical properties, the other four sub-indices are grouped together into one index (labelled INPR index excluding sub-index for "Ongoing Supervision").

Table 12. Correlations between prudential regulation indicators and competition in insurance

\begin{tabular}{l|c|c|c}
\hline \multicolumn{1}{c|}{ Correlations } & \multicolumn{2}{c}{ Net Underwriting Margin In } \\
\cline { 2 - 3 } & All Insurance Sector & Life-Insurance Sector & Non-life Insurance \\
\hline Insurance Prudential Regulation (INPR) Index & -0.31 & $-0.47^{* *}$ & -0.13 \\
Sub-index for "Ongoing Supervision" & -0.03 & -0.02 & -0.08 \\
INPR index excluding sub-index for "Ongoing Supervision" & $-0.40^{* *}$ & $-0.60^{* * *}$ & -0.14 \\
\hline
\end{tabular}

Note: ${ }^{* * *},{ }^{* *}$ indicate statistical significance at $1 \%$ and $5 \%$ levels.

55. The preliminary findings derived from simple correlations are supported by cross-sectional regressions presented in Table 13. Two sets of regressions have been run, one using average net underwriting margins over the 2001-2006 period as a dependent variable, and another using yearly net underwriting margins in a pooled sample of annual observations. ${ }^{51}$ In line with the analysis in the banking section, most of the regressions control for a set of macro-economic variables. The results confirm that the overall INPR index is negatively associated with net underwriting margins in the insurance sector, consistent with the hypothesis that stronger and better regulation enhances competition in the insurance industry. This link, however, is consistently significant only for life insurance.

56. When the overall index is split into ongoing supervision and the aggregated remaining subcomponents (INPR-3), these two sub-indices come out with opposite signs in the regressions. Indeed, the "ongoing supervision" sub-index becomes positive and significant for life-insurance, implying that active supervision by financial authorities would tend to increase net underwriting margins in this sector. The positive link between active ongoing supervision and the increase in underwriting margins is suggestive of the imperfection of the underwriting margin as a measure of competition in life insurance. However, it might also reflect the possibility of serious incentive problems in the life insurance sector: with large parts of life insurance contracts being de facto savings or pension plans, promising overly optimistic payouts could increase the market share of an insurance company. The resulting collection of insufficient premiums may then be reflected in (overly) low underwriting margins. While such a business model would obviously be neither sustainable nor in the long-term interest of shareholders, it may bring short- and medium term benefits for a company's management. Successful regulation would prevent such practices, which could result in countries with stronger ongoing supervision having higher underwriting margins.

51. Qualitatively similar results are obtained when using net profit margins, defined as premiums minus claims and minus gross operating expenses, divided by premiums. 
ECO/WKP(2009)76

Table 13. Prudential insurance regulation and net underwriting margins

\begin{tabular}{|c|c|c|c|c|c|c|c|c|c|c|c|c|c|c|c|c|c|c|}
\hline \multirow{3}{*}{$\begin{array}{l}\text { Dependent Variable: } \\
\text { Net Underwriting Margin } \\
\text { in the Insurance Sector }\end{array}$} & \multicolumn{6}{|c|}{ All Insurance Sector } & \multicolumn{6}{|c|}{ Life Insurance } & \multicolumn{6}{|c|}{ Non-life Insurance } \\
\hline & \multirow{2}{*}{\multicolumn{4}{|c|}{ Averages on 2001-2006 }} & \multirow{2}{*}{\multicolumn{2}{|c|}{$\begin{array}{l}\text { All Years } \\
(5) \quad \text { (6) }\end{array}$}} & \multicolumn{4}{|c|}{ Averages on 2001-2006 } & \multirow{2}{*}{\multicolumn{2}{|c|}{\begin{tabular}{l}
\multicolumn{2}{|c|}{ All Years } \\
$(11)$
\end{tabular}}} & \multicolumn{4}{|c|}{ Averages on 2001-2006 } & \multirow{2}{*}{\multicolumn{2}{|c|}{$\begin{array}{c}\text { All Years } \\
(17)\end{array}$}} \\
\hline & (1) & & & (4) & & (6) & $(7)$ & (8) & (9) & (10) & & (12) & (13) & $(14)$ & (15) & $(16)$ & & \\
\hline INPR index & $\begin{array}{r}-0.03 \\
(0.02)\end{array}$ & $\begin{array}{l}-0.02 \\
(0.02)\end{array}$ & & & $\begin{array}{l}-0.03 \text { ** } \\
(0.01)\end{array}$ & & $\begin{array}{l}-0.07 \text { ** } \\
(0.03)\end{array}$ & $\begin{array}{l}-0.07 * * \\
(0.03)\end{array}$ & & & $\begin{array}{l}-0.06 * * * \\
(0.02)\end{array}$ & & $\begin{array}{r}-0.02 \\
(0.02)\end{array}$ & $\begin{array}{r}0.01 \\
(0.03)\end{array}$ & & & $\begin{array}{r}0.00 \\
(0.01)\end{array}$ & \\
\hline $\begin{array}{l}\text { INPR index excluding } \\
\text { ongoing supervision }\end{array}$ & & & $\begin{array}{l}-0.05 \text { ** } \\
(0.02)\end{array}$ & $\begin{array}{l}-0.05^{*} \\
(0.03)\end{array}$ & & $\begin{array}{l}-0.06 * * * \\
(0.01)\end{array}$ & & & $\begin{array}{l}-0.12 * * \star \\
(0.03)\end{array}$ & $\begin{array}{l}-0.12 * * * \\
(0.03)\end{array}$ & & $\begin{array}{l}-0.12 * \star * \\
(0.02)\end{array}$ & & & $\begin{array}{r}-0.02 \\
(0.03)\end{array}$ & $\begin{array}{r}0.00 \\
(0.03)\end{array}$ & & $\begin{array}{r}0.00 \\
(0.01)\end{array}$ \\
\hline $\begin{array}{l}\text { Ongoing supervision } \\
\text { INPR index }\end{array}$ & & & $\begin{array}{r}0.02 \\
(0.02)\end{array}$ & $\begin{array}{r}0.03 \\
(0.02)\end{array}$ & & $\begin{array}{l}0.02 * * * \\
(0.01)\end{array}$ & & & $\begin{array}{c}0.03^{*} \\
(0.02)\end{array}$ & $\begin{array}{l}0.05 * * \\
(0.02)\end{array}$ & & $\begin{array}{l}0.04^{* * *} \\
(0.01)\end{array}$ & & & $\begin{array}{r}0.00 \\
(0.02)\end{array}$ & $\begin{array}{r}0.01 \\
(0.02)\end{array}$ & & $\begin{array}{r}0.01 \\
(0.01)\end{array}$ \\
\hline GDP per capita & & $\begin{array}{l}-1.2 \mathrm{E}-06 \\
(2.9 \mathrm{E}-06)\end{array}$ & & $\begin{array}{l}-1.6 \mathrm{E}-06 \\
(2.8 \mathrm{E}-06)\end{array}$ & $\begin{array}{r}3.7 \mathrm{E}-07 \\
(1.5 \mathrm{E}-06)\end{array}$ & $\begin{array}{r}5.4 \mathrm{E}-07 \\
(1.4 \mathrm{E}-06)\end{array}$ & & $\begin{array}{r}4.4 \mathrm{E}-06 \\
(3.8 \mathrm{E}-06)\end{array}$ & & $\begin{array}{r}3.6 \mathrm{E}-06 \\
(3.3 \mathrm{E}-06)\end{array}$ & $\begin{array}{r}2.6 \mathrm{E}-06 \\
(2.0 \mathrm{E}-06)\end{array}$ & $\begin{aligned} 2.9 \mathrm{E}-06 \\
(1.8 \mathrm{E}-06)\end{aligned}$ & & $\begin{aligned} & -2.6 E-06 \\
(3.4 E-06) & \end{aligned}$ & & $\begin{array}{r}-2.7 \mathrm{E}-06 \\
(3.4 \mathrm{E}-06)\end{array}$ & $\begin{array}{l}-1.3 \mathrm{E}-06 \\
(1.5 \mathrm{E}-06)\end{array}$ & $\begin{array}{l}2.6 \mathrm{E}-06 \text { *** } \\
(8.2 \mathrm{E}-07)\end{array}$ \\
\hline $\begin{array}{l}\text { Growth of GDP } \\
\text { per capita }\end{array}$ & & $\begin{array}{c}3.78 * \\
(2.17)\end{array}$ & & $\begin{array}{l}4.98 * * \\
(2.17)\end{array}$ & $\begin{array}{l}2.46 * * * \\
(0.80)\end{array}$ & $\begin{array}{l}3.06 * * * \\
(0.77)\end{array}$ & & $\begin{array}{r}1.79 \\
(2.85)\end{array}$ & & $\begin{array}{l}4.35{ }^{*} \\
(2.53)\end{array}$ & $\begin{array}{l}1.87^{*} \\
(1.09)\end{array}$ & $\begin{array}{l}2.911^{* * *} \\
(1.00)\end{array}$ & & $\begin{array}{l}4.94 \text { ** } \\
(2.49)\end{array}$ & & $\begin{array}{l}5.22 \text { ** } \\
(2.66)\end{array}$ & $\begin{array}{l}2.511^{* * *} \\
(0.81)\end{array}$ & $\begin{array}{l}2.57^{* * *} \\
(0.82)\end{array}$ \\
\hline Inflation rate & & $\begin{array}{r}1.37 \\
(2.51)\end{array}$ & & $\begin{array}{r}-1.52 \\
(2.91)\end{array}$ & $\begin{array}{l}1.76 * \\
(0.93)\end{array}$ & $\begin{array}{r}0.19 \\
(0.96)\end{array}$ & & $\begin{array}{r}3.66 \\
(3.30)\end{array}$ & & $\begin{array}{r}-2.27 \\
(3.40)\end{array}$ & $\begin{array}{c}2.23{ }^{*} \\
(1.26)\end{array}$ & $\begin{array}{r}-0.41 \\
(1.25)\end{array}$ & & $\begin{array}{r}-1.02 \\
(2.87)\end{array}$ & & $\begin{array}{l}-1.82 \\
(3.59)\end{array}$ & $\begin{array}{r}1.15 \\
(0.96)\end{array}$ & $\begin{array}{r}0.93 \\
(1.05)\end{array}$ \\
\hline Short-term interest rate & & $\begin{array}{r}-0.02 \\
(0.02)\end{array}$ & & $\begin{array}{r}-0.01 \\
(0.02)\end{array}$ & $\begin{array}{l}-0.01 \\
(0.01)\end{array}$ & $\begin{array}{r}-0.01 \\
(0.01)\end{array}$ & & $\begin{array}{r}0.00 \\
(0.02)\end{array}$ & & $\begin{array}{r}0.02 \\
(0.02)\end{array}$ & $\begin{array}{r}0.00 \\
(0.01)\end{array}$ & $\begin{array}{r}0.01 \\
(0.01)\end{array}$ & & $\begin{array}{r}0.00 \\
(0.02)\end{array}$ & & $\begin{array}{r}0.00 \\
(0.02)\end{array}$ & $\begin{array}{r}0.00 \\
(0.01)\end{array}$ & $\begin{array}{r}0.00 \\
(0.01)\end{array}$ \\
\hline Time-Effects & No & No & No & No & Yes & Yes & No & No & No & No & Yes & Yes & No & No & No & No & Yes & Yes \\
\hline Observations & 26 & 26 & 26 & 26 & 135 & 135 & 26 & 26 & 26 & 26 & 136 & 136 & 26 & 26 & 26 & 26 & 141 & 141 \\
\hline Adj. R2 & 0.06 & 0.11 & 0.12 & 0.19 & 0.15 & 0.25 & 0.18 & 0.21 & 0.39 & 0.43 & 0.15 & 0.30 & -0.02 & 0.03 & -0.07 & -0.02 & 0.18 & 0.17 \\
\hline
\end{tabular}

Note: The adjusted $\mathrm{R}^{2}$ introduces a penalty based on the number of explanatory variables, and hence can be negative when the explanatory power of regressors is very low as in columns (13), (15) and (16) 
57. Summing up the findings, as in banking, there is no general support for the view that a stronger prudential regulatory framework reduces competition in the insurance sector. If anything, more stabilityoriented regulation seems to be associated with greater competition.

\section{Conclusion}

58. This paper investigates the relationship between a range of stability-oriented regulatory policies for the banking and insurance industries and outcomes for stability and competition in these sectors. Based on survey information on financial market regulation, policy indicators for eight different areas of prudential banking regulation are constructed, in addition to indicators for the insurance sector.

59. Despite data limitations, a number of interesting results are obtained. First, the policy indicators display a clear link to two measures of how strongly countries have been affected by the recent financial crisis, namely share price declines in banking and the net fiscal costs of financial sector rescue packages. Beyond the recent crisis, they are also related to measures of financial soundness compiled by the IMF. These findings give some confidence that stronger prudentially-oriented policies are effective in enhancing the stability of banking and insurance systems, and that the constructed indicators reflect at least some of the variation across countries in this area.

60. Second, when relating the stringency of prudential policies to competition outcomes, the indicators do not point to stronger prudential regulation having adverse effects on the strength of competition in general. In other words, the results do not support the view that there is a general trade-off between stability and competition. Some areas of prudential regulation would even appear to be associated with greater competition. Most notable in this regard is the strength of the banking supervisor, which appears to enhance both stability and competition in banking (the latter possibly because strong supervision helps level the playing field across all competitors). In a few specific areas, however, the analysis identifies trade-offs between the strength of prudential regulation and competition. In particular, tighter regulation with respect to entry rules and ownership structures appears to weaken competition in the banking sector.

61. Although the analytical results obtained in this paper rely largely on pre-crisis information, the identified relationships may provide useful insights for ongoing and future reforms of prudential regulation in financial markets - although such reforms would also have to take into account other considerations, including the lessons learned from the recent crisis in areas that are not covered in this paper. 


\section{REFERENCES}

Ahrend, R., Cournède, B. and R. Price (2008), "Monetary Policy, Market Excesses and Financial Turmoil”, OECD Economics Department Working Papers No. 597.

Beck, T. (2008), "Bank Competition and Financial Stability: Friends or Foes?”, in Bank Indonesia and Banco de Mexico (eds), Competition in the Financial Sector.

Beck, T., A. Demirgüç-Kunt and R. Levine (2006a), "Bank Concentration, Competition, and Crises: First Results", Journal of Banking and Finance, Vol. 30.

Beck, T., A. Demirgüç-Kunt and R. Levine (2006b), "Bank Concentration and Fragility: Impact and mechanics" in R. Stulz and M. Carey (eds.), The Risks of Financial Institutions, National Bureau of Economic Research, Cambridge, MA.

Besanko, D. and A. Thakor (1992), "Banking Deregulation: Allocational Consequences of Relaxing Entry Barriers", Journal of Banking \& Finance, Vol. 16.

Bikker, J.A., L. Spierdijk and P. Finnie (2006), "Misspecification in the Panzar-Rosse Model: Assessing Competition in the Banking Industry", DNB Working Paper no. 114, De Nederlandsche Bank, Amsterdam.

Black J., and S. Jacobzone (2009), "Tools for Regulatory Quality and Financial Sector Regulation, a Cross-country Perspective", OECD Working Papers on Public Governance, forthcoming.

Blundell-Wignall, A., P. Atkinson and S. Hoon Lee (2008), "The Current Financial Crisis: Causes and Policy Issues", Financial Market Trends, Vol. 95.

Borio, C. (2003),“Towards a Macro-Prudential Framework for Financial Supervision and Regulation?”, CESifo Economic Studies, Vol. 49.

Claessens, S. and L. Laeven (2004), "What Drives Bank Competition? Some International Evidence", Journal of Money, Credit and Banking, Vol. 36.

Demirgüc-Kunt, A., and H. Huizinga (1999), "Determinants of Commercial Bank Interest Margins and Profitability: Some International Evidence", World Bank Economic Review, Vol. 13.

Demirguic-Kunt, A., Detragiache, E. and T. Tressel (2006), "Banking on the Principles: Compliance with Basel Core Principles and Bank Soundness", IMF Working Paper No. 06/242.

Goddard, J. and J. Wilson (2009), "Measuring Competition in Banking: A Disequilibrium Approach" Working Paper, University of St Andrews, Great Britain.

IMF Fiscal Affairs Department (2008), "Companion Paper - The State of Public Finances: Outlook and Medium-Term Policies After the 2008 Crisis". 
Jayaratne, J. and P. Strahan (1996), "The Finance-Growth Nexus: Evidence from Bank Branch Deregulation." Quarterly Journal of Economics, Vol. 111, No. 3, pp. 639-670.

Jimenez, G., J.A. Lopez, and J. Saurina (2007), "How Does Competition Impact Bank Risk-Taking?", Federal Reserve Bank of San Francisco Working Paper No. 2007-23.

Levine, R. (1997), "Financial Development and Economic Growth: Views and Agenda", Journal of Economic Literature, Vol. 35.

Levine, R. (2004), “Finance and Growth: Theory and Evidence”, NBER Working Paper No. 10766.

Levine, R. and A. Demirgüc-Kunt (2008), "Finance, Financial Sector Policies, and Long-Run Growth", World Bank Commission on Growth and Development, Working Paper No. 11.

Moulton, B.R. (1991), "An Illustration of a Pitfall in Estimating the Effects of Aggregate Variables on Micro Units", Review of Economics and Statistics 72: 334-338.

OECD (2009), “Competition and Financial Markets”, Competition Policy Roundtable.

Panzar, J.C. and J. N. Rosse (1987), “Testing for Monopoly Equilibrium”, Journal of Industrial Economics, Vol.35.

Ratnovski, L. and R. Huang (2009), "Why Are Canadian Banks More Resilient?”, IMF Working Paper No. 09/152.

Schaeck, K., M. Čihák, and S. Wolfe (2009), “Are More Competitive Banking Systems More Stable?”, Journal of Money, Credit and Banking, Vol. 41.

Schaeck, K., and M. Čihák (2007), "Banking Competition and Capital Ratios”, IMF Working Paper No. $07 / 216$.

de Serres, A., S. Kobayakawa, T. Sløk and L. Vartia (2006), "Regulation of Financial Systems and Economic Growth", OECD Economics Department Working Papers No. 506.

Stiroh, K. J. and P. Strahan (2003), "Competitive Dynamics of Deregulation: Evidence from U.S. Banking." Journal of Money, Credit and Banking, Vol. 35.

White, W. (2006), "Pro-Cyclicality in the Financial System: Do We Need a New Macro-Financial Stabilisation Framework?", BIS Working Papers No.193. 


\begin{abstract}
ANNEX
A1. Banking regulation indicators

62. This section first presents the indicators for prudential banking regulation which have been constructed for OECD countries, as well as for candidate countries for accession (AC) and enhanced engagement countries (EE5). It then gives a detailed description of the coding of the indicators. Finally, it turns to robustness assessments.
\end{abstract}

\title{
A1.1 A presentation of the indicators
}

1. The relatively detailed information on prudential regulation of the banking sector allows the construction of indicators for different areas of financial regulation. Ideally, each indicator would capture the regulation for specific aspects of the banking sector. In practice, however, some aggregation over different fields is required to obtain a large enough number of data-points and ensure sufficient robustness of indicators. With this in mind, prudential banking regulation is divided into eight areas, with the exact questions underlying each of the indicators being presented below in this Annex. The eight areas are:

- Capital Requirements

- Liquidity and Diversification Requirements

- Accounting and Provisioning Requirements

- External Auditing and Information Disclosure Requirements

- Entry Rules and Ownership Structures

- $\quad$ Exit Rules and Disciplining Devices

- Depositor Protection

- Strength of Supervisory Authority

2. Figures A1 and A2 sum up for each country the information contained in the banking regulation indicators. This allows identifying each country's stance (relative to the OECD average) on prudential regulations prior to the current crisis (as of 2005/06). It should be noted that the cardinal values are not fully comparable across the different indicators, and the figures should hence mainly be seen as indicating the relative position of a country vis-à-vis others. The indicators show that countries often couple a relatively strong regulatory stance in some areas with lighter regulation in other fields, implying that only very few OECD countries are consistently at or above OECD averages in all dimensions of banking regulation. 
Figure A1. Strength of Banking Prudential Regulation by Country as of 2005/06 - OECD Countries

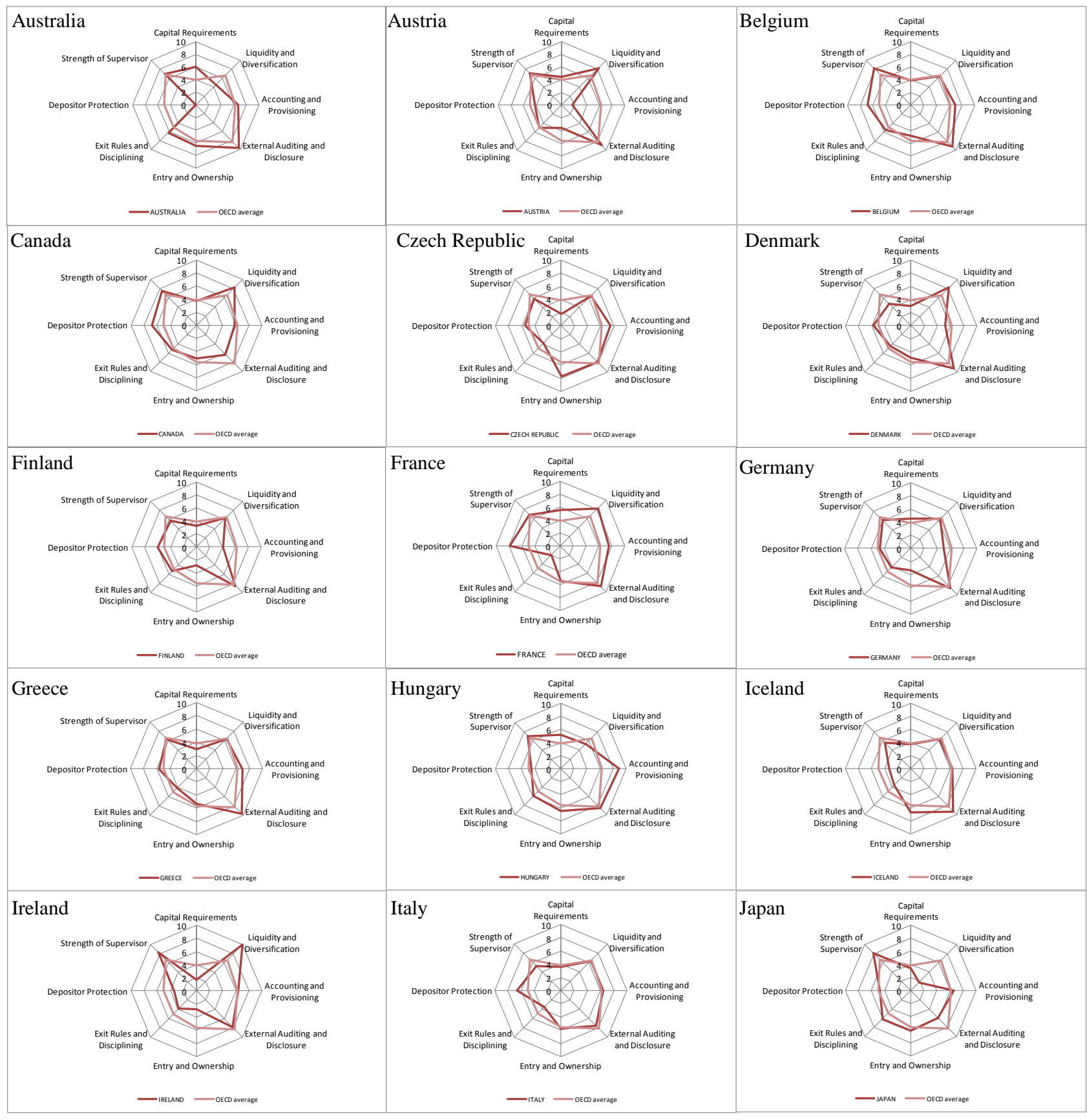


Figure A1 (continued)

\section{Strength of Banking Prudential Regulation by Country as of 2005/06 - OECD Countries}

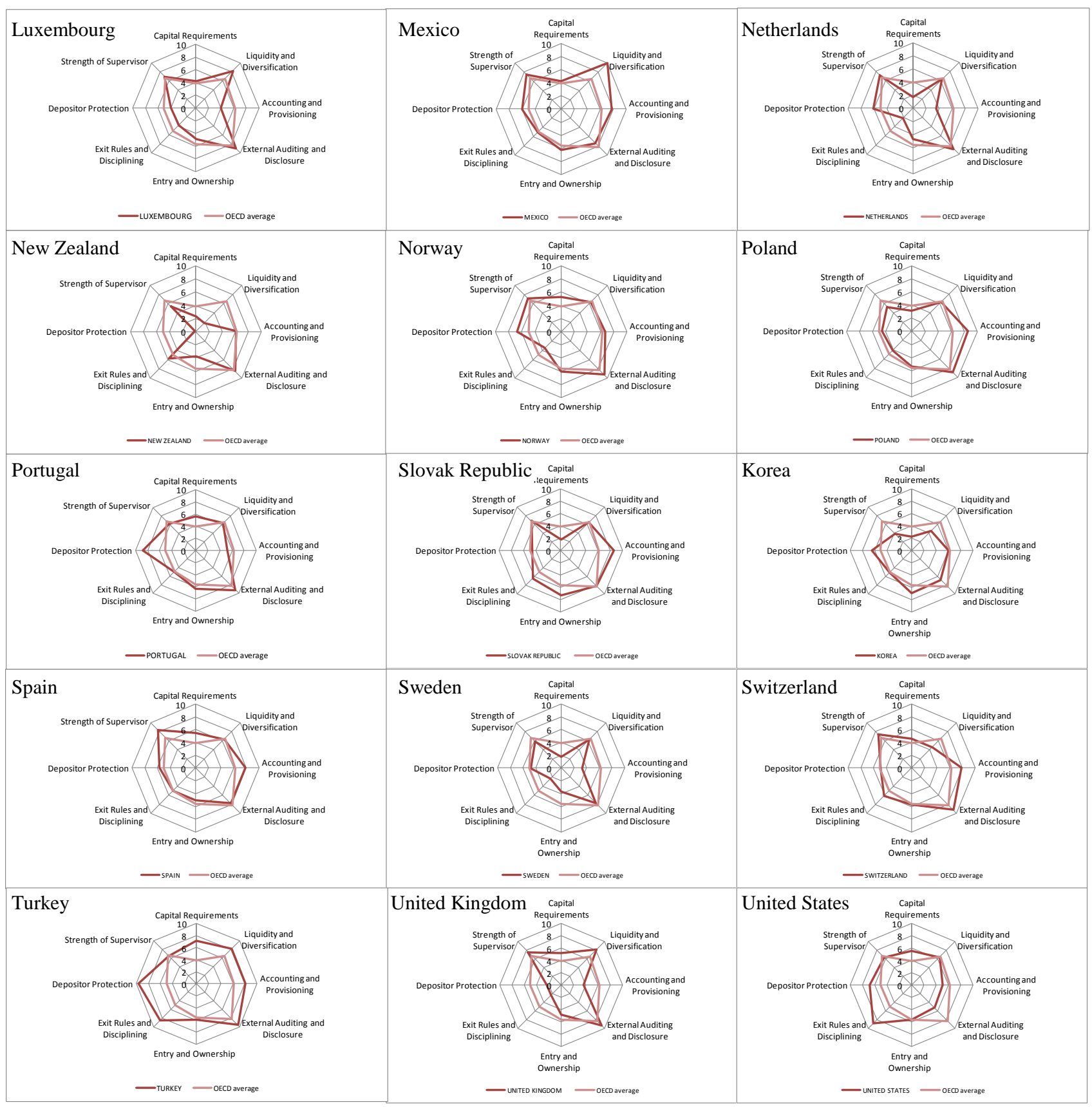


Figure A2. Strength of Banking Prudential Regulation by Country as of 2005/06 - AC and EE5 Countries ${ }^{52}$

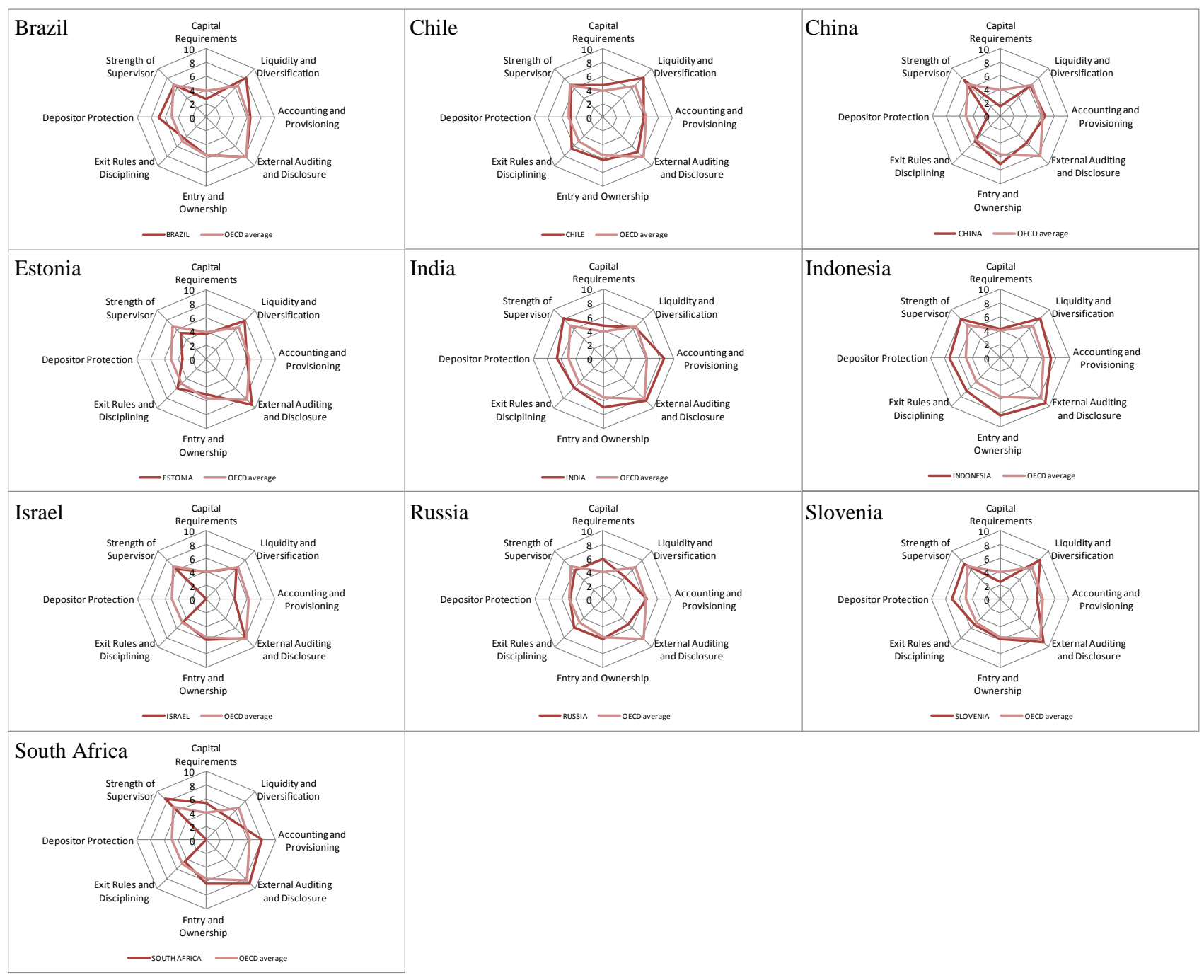

3. With the caveat that the effective regulatory stance may differ from the regulatory framework captured by the indicators, the indicators could be interpreted as pointing to relatively lighter regulatory stances in the following areas and countries:

- Capital requirements: Brazil, China, the Czech Republic, Denmark, Greece, Ireland, Israel, Netherlands, New Zealand, Poland, Slovak Republic, Slovenia, South Korea and Sweden.

- Accounting and provisioning requirements: Austria, Finland, Germany, Israel, Luxemburg Netherlands, Portugal, Slovenia, Sweden, United Kingdom and United States.

- Liquidity and diversification requirements: Australia, Japan, New Zealand, Russia, South Africa, South Korea and Switzerland.

52. $\quad$ AC countries $=$ OECD accession candidate countries (Chile, Estonia, Israel, Russia and Slovenia), EE5 countries = countries with enhanced engagement with the OECD (Brazil, China, India, Indonesia and South Africa). 
- Exit rules and disciplining devices: Czech Republic, France, Germany, Greece, Iceland, Ireland, Italy, Luxembourg, Netherlands, Norway, Poland, Portugal, Sweden and United Kingdom.

- Strength of the supervisory authority: Denmark, Estonia, Iceland, Italy, Poland and South Korea.

- External auditing and information disclosure requirements: Canada, Chile, China, Japan, Russia, South Korea and the United States.

- Depositor protection: abstracting from the countries without an explicit deposit insurance scheme (Australia, China, Israel, New Zealand, South Africa) ${ }^{53}$ the indicators point to depositor protection prior to the current crisis having been relatively weak in Estonia, Iceland, Ireland, Luxembourg, and the United Kingdom.

4. As the banking regulation survey has been carried out three times, it is possible to compare the evolution of the prudential indicators over time (sets I, II and III refer respectively to surveys approximately referring to the regulatory situation in 1998, 2002 and 2006). As questionnaires were slightly different across waves, indices have been calculated on the basis of consistent sets of questions across time. Changes across time therefore reflect observed changes in regulation rather than changes in the way regulation has been measured. Figure A3 depicts average changes of BPR indices. For the period of 1998-2006 as a whole, there was a net increase in liquidity and diversification, as well as in external auditing and information disclosure requirements. The authority of supervisory agencies was generally reinforced. In contrast, there was a net decrease in the strength of regulation with respect to entry rules and ownership structures, exit rules and disciplining devices, as well as in depositor protection. There may also be some cyclical component in regulation, as five of the eight indicators saw some increase during the 1998-2002 period, whereas six saw some decrease over 2002-2006. This may reflect regulatory cycles, possibly connected with efforts to tighten regulation following financial turmoil in a number of emerging markets in the late 1990s and early 2000s, and a global wave of deregulation over the following years.

53. In some countries (e.g. Australia), depositors are in a privileged position as they have first call on the assets of banks. This arrangement substitutes to some degree for deposit insurance, but has not been taken into account in the depositor protection indicator as comparable cross country data are not available. 
Figure A3. Evolution of Prudential Banking Regulation Indicators (OECD averages)

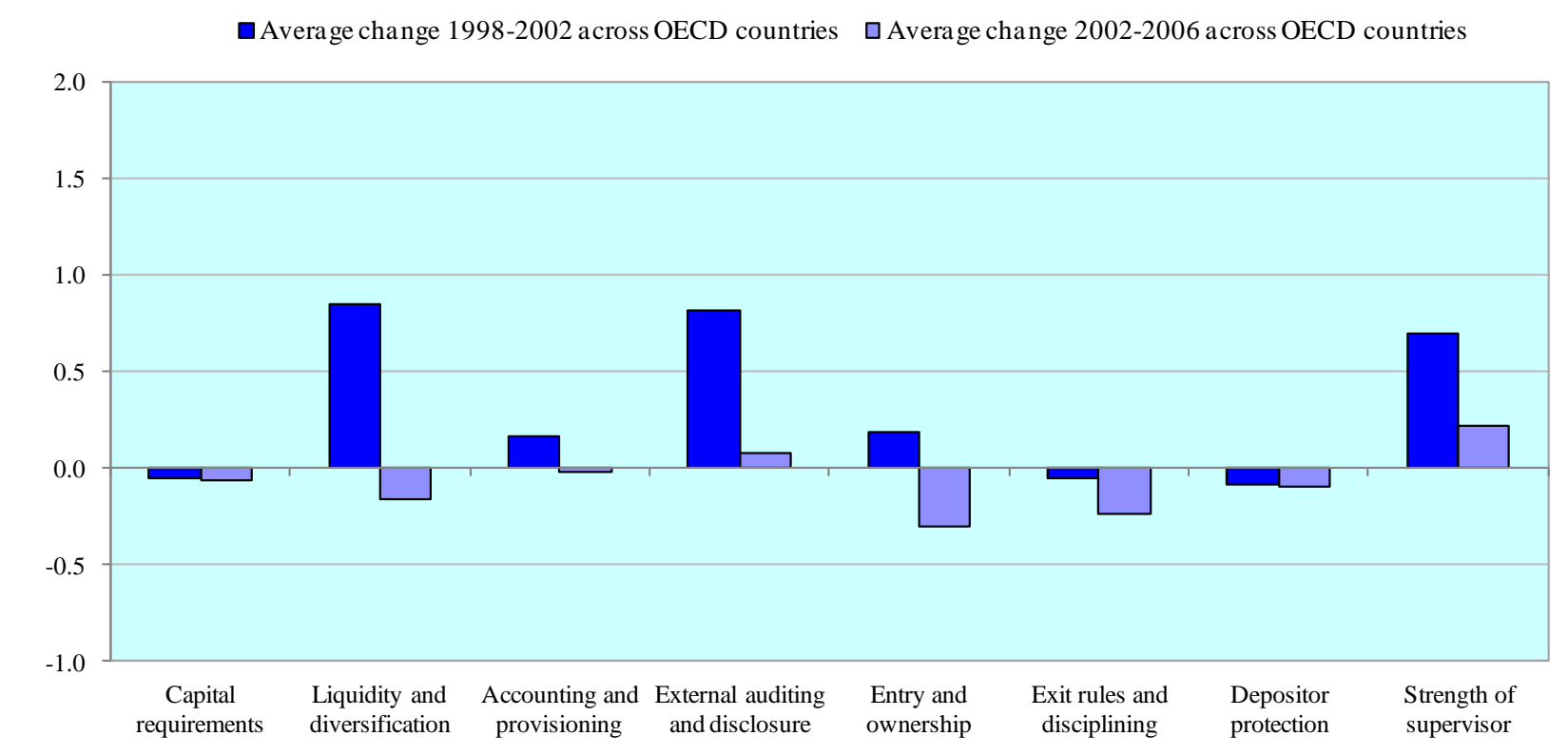

Note: Changes are measured in units of one standard deviation.

5. The country-specific developments in prudential banking regulation presented in Tables A1 and A2 confirm the picture drawn from the average changes of the indicators. Indeed, a large majority of countries tightened external auditing and information disclosure rules, as well as liquidity and diversification requirements in the 1998-2002 period, and increased the strength of the supervisor. In contrast, from 2002 to 2006 many countries loosened entry and ownership requirements, as well as exit rules and disciplining devices. Many OECD countries reinforced, however, the strength of supervisory authorities over the 2002-2006 period, contrary to a number of candidate countries for accession and enhanced engagement countries where supervisory strength was weakened. 
Table A1. Evolution of Banking Indicators by Country (OECD)

\begin{tabular}{|c|c|c|c|c|c|c|c|c|c|c|c|c|c|c|c|c|}
\hline & \multicolumn{8}{|c|}{ Variation Between 1998 and 2002} & \multicolumn{8}{|c|}{ Variation Between 2002 and 2006} \\
\hline & 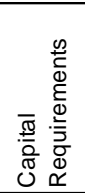 & 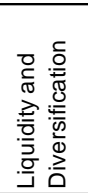 & 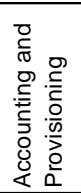 & 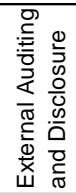 & 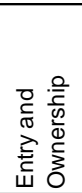 & 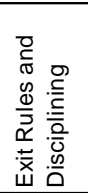 & 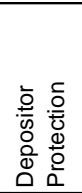 & 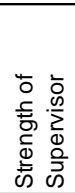 & 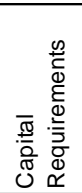 & 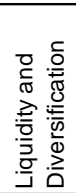 & 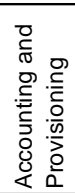 & 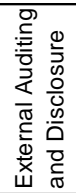 & 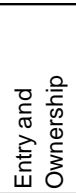 & 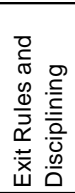 & 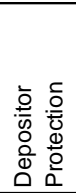 & 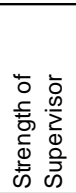 \\
\hline Australia & - & 0 & 0 & 0 & ++ & - & --- & + & + & ++ & - & +++ & + & +++ & 0 & +++ \\
\hline Austria & - & +++ & - & -- & + & - & --- & + & -- & 0 & --- & +++ & --- & --- & +++ & ++ \\
\hline Belgium & --- & --- & ++ & ++ & - & - & -- & t++ & - & +++ & + & 0 & -- & - & +++ & +++ \\
\hline Canada & 0 & 0 & 0 & 0 & - & + & -- & 0 & + & t++ & ++ & ++ & - & ++ & ++ & ++ \\
\hline Czech Republic & + & t++ & +++ & + & +++ & --- & -- & -- & 0 & -- & - & 0 & - & - - & ++ & +++ \\
\hline Denmark & - & --- & 0 & ++ & 0 & 0 & -- & + & --- & +++ & + & 0 & - & - & ++ & ++ \\
\hline Finland & - & +++ & -- & 0 & - & t+ & + & -- & -- & -- & - & 0 & --- & ++ & ++ & ++ \\
\hline France & - & +++ & 0 & t++ & - & ++ & --- & + & + & 0 & - & - & ++ & 0 & +++ & + \\
\hline Germany & + & +++ & 0 & +++ & ++ & - & - & - & - & -- & +++ & 0 & - & +++ & - & ++ \\
\hline Greece & + & +++ & +++ & +++ & - & 0 & - & +++ & + & -- & + & 0 & -- & -- & - & -- \\
\hline Hungary & - & 0 & + & 0 & ++ & 0 & - & +++ & +++ & -- & -- & 0 & -- & -- & -- & + \\
\hline Iceland & +++ & 0 & ++ & ++ & - & + & - & +++ & 0 & -- & - & +++ & + & - & ++ & - \\
\hline Ireland & --- & 0 & 0 & ++ & - & + & --- & ++ & - & t++ & - & 0 & -- & - & - & t++ \\
\hline Italy & - & +++ & 0 & +++ & + & 0 & +++ & 0 & + & + & + & 0 & -- & - & -- & -- \\
\hline Japan & - & +++ & 0 & t++ & - & -- & +++ & +++ & 0 & --- & - & 0 & - & - & -- & + \\
\hline Korea, Rep. & --- & 0 & ++ & t++ & +++ & -- & ++ & ++ & 0 & - & - & --- & -- & --- & --- & --- \\
\hline Luxembourg & + & +++ & 0 & - & -- & - & ++ & +++ & - & 0 & --- & 0 & + & --- & -- & + \\
\hline Mexico & + & +++ & -- & ++ & ++ & -- & + & +++ & -- & 0 & ++ & 0 & --- & ++ & - & ++ \\
\hline Netherlands & - & t++ & -- & t++ & 0 & - & - & t++ & -- & -- & ++ & 0 & -- & 0 & - & --- \\
\hline New Zealand & - & 0 & - & +++ & 0 & - & --- & + & -- & ++ & - & +++ & +++ & + & + & + \\
\hline Norway & na & na & na & na & na & na & na & na & t++ & 0 & - & 0 & + & -- & - & +++ \\
\hline Poland & + & ++ & 0 & ++ & 0 & --- & --- & +t & -- & + & - & ++ & -- & + & - & ++ \\
\hline Portugal & + & t++ & 0 & t++ & - & -- & + & + & + & -- & - & ++ & + & - & + & - \\
\hline Slovak Republic & + & 0 & 0 & +++ & + & +++ & - & +++ & -- & -- & + & --- & - & -- & + & --- \\
\hline Spain & + & +++ & -- & - & - & 0 & t++ & + & - & -- & + & +++ & --- & + & -- & t+t \\
\hline Sweden & + & 0 & 0 & + & - & ++ & + & --- & 0 & +++ & + & -- & --- & - & + & ++ \\
\hline Switzerland & - & t++ & 0 & 0 & t++ & - & t++ & + & - & --- & + & 0 & - & - & -- & - \\
\hline Turkey & + & +++ & +++ & +++ & +++ & +++ & +++ & ++ & +++ & 0 & -- & 0 & - & - & + & --- \\
\hline United Kingdom & - & 0 & 0 & 0 & - & + & --- & +++ & - & 0 & - & +++ & - & --- & --- & + \\
\hline United States & +t & +++ & 0 & - & + & -- & - & +++ & -- & + & + & -- & - & ++ & -- & - \\
\hline $\begin{array}{l}\text { Number of countries increasing } \\
\text { prudential regulation }\end{array}$ & 13 & 16 & 7 & 20 & 11 & 10 & 12 & 22 & 9 & 10 & 13 & 9 & 7 & 8 & 14 & 21 \\
\hline $\begin{array}{l}\text { Number of countries decreasing } \\
\text { prudential regulation }\end{array}$ & 15 & 2 & 6 & 3 & 14 & 14 & 17 & 5 & 15 & 13 & 17 & 5 & 23 & 20 & 15 & 9 \\
\hline
\end{tabular}

Note: $+(-)$ represents an increase (a decrease) of the index by less than half a standard error; ++ and $+++(--$ and ---$)$ represent an increase (a decrease) of the index by, respectively, half to one standard error, and by more than one standard error. 
Table A2. Evolution of Banking Indicators by Country (AC and EE5)

\begin{tabular}{|c|c|c|c|c|c|c|c|c|c|c|c|c|c|c|c|c|}
\hline & \multicolumn{8}{|c|}{ Variation Between 1998 and 2002} & \multicolumn{7}{|c|}{ Variation Between 2002 and 2006} & \multirow[b]{2}{*}{ 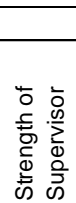 } \\
\hline & 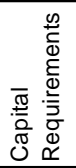 & 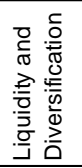 & 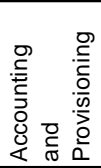 & 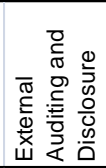 & 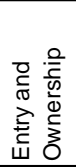 & 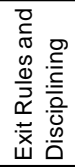 & 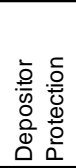 & 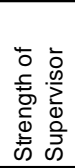 & 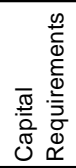 & 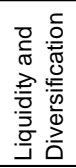 & 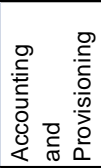 & 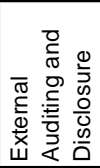 & 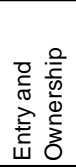 & 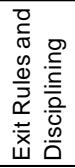 & 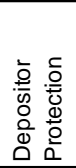 & \\
\hline Brazil & + & 0 & 0 & 0 & - & --- & +++ & + & +++ & + & 0 & -- & 0 & - & - & - \\
\hline Chile & - & +++ & 0 & ++ & +++ & - & - & ++ & +++ & 0 & 0 & --- & -- & -- & + & - \\
\hline Estonia & --- & t++ & t+ & ++ & 0 & t+ & + & t++ & t++ & - & 0 & --- & 0 & - & --- & -- \\
\hline India & + & 0 & ++ & +++ & ++ & ++ & +++ & +++ & +++ & 0 & -- & -- & 0 & - & - & --- \\
\hline Israel & + & +++ & --- & +++ & - & ++ & --- & ++ & +++ & 0 & --- & - & ++ & - & + & -- \\
\hline Russian Federation & - & 0 & + & + & - & ++ & --- & --- & +++ & + & -- & -- & 0 & + & --- & +++ \\
\hline Slovenia & + & 0 & + & + & ++ & -- & + & ++ & t++ & -- & 0 & ++ & 0 & -- & - & -- \\
\hline South Africa & + & 0 & 0 & +++ & -- & +++ & --- & +++ & +++ & + & -- & +++ & - & - & ++ & 0 \\
\hline $\begin{array}{l}\text { Number of countries increasing } \\
\text { prudential regulation }\end{array}$ & 5 & 3 & 4 & 7 & 3 & 5 & 4 & 7 & 10 & 3 & 0 & 2 & 1 & 1 & 3 & 1 \\
\hline $\begin{array}{l}\text { Number of countries decreasing } \\
\text { prudential regulation }\end{array}$ & 3 & 0 & 1 & 0 & 4 & 3 & 4 & 1 & 0 & 2 & 4 & 6 & 2 & 7 & 5 & 6 \\
\hline
\end{tabular}

Note: $+(-)$ represents an increase (a decrease) of the index by less than half a standard error; ++ and $+++(--$ and ---$)$ represent an increase (a decrease) of the index by, respectively, half to one standard error, and by more than one standard error. 
ECO/WKP(2009)76

\section{A1.2 Indicator coding}

6. This section gives a detailed description of the information underlying the construction of the survey-based banking indicators, and the exact way in which this information has been aggregated. The overwhelming part of the information is taken from the freely available Bank Regulation and Supervision database published by the World Bank. ${ }^{54}$ The data come from three consecutive surveys, the results of which were released in 2001, 2003 and 2007, with data pertaining to 1998-2000, 2001-2002 and 2005-2006, respectively. These three rounds of surveys are referred to as waves I, II and III in what follows. OECD member as well as AC countries were given the opportunity to verify the data extracted from the Bank Regulation and Supervision database that are used in the construction of the indicators.

7. The indicators have been constructed from the underlying data in a relatively simple manner. The World Bank survey data on banking regulation are aggregated by area of regulation, using for each of the eight areas all questions available for a sufficient number of countries. As a starting point, answers to simple qualitative questions (Yes/No) are - unless stated otherwise - coded as either 10 (the regulation is good from a prudential point of view) or 0 (the regulation is bad from a prudential point of view). ${ }^{55}$ For more complex questions, qualitative answers are ordered and matched to the 0 to 10 scale on a judgmental basis, typically in a linear way. ${ }^{56}$ Smaller scores reflect more moderate regulation. The exact coding of all the answers is given in the Annex. In the construction of the indicators, a weight is given to each question (low $=1$, normal $=2$, high $=3$ ) which principally reflects the perceived importance of the question for prudential regulation in the respective area. Weights may also reflect data quality (i.e. lower quality information may obtain a lower weight), and be influenced by the desire to strike a balance between different issues within a sector (i.e. questions that may report partly redundant information may receive a lower weighting). The scores of the questions underlying an indicator are then aggregated by using the aforementioned weights. For the indicators based on information from the FSAP reports about compliance with principles, the compliance with each principle is assessed on a scale between 0 and $10,{ }^{57}$ and the indicator value for the sector is the simple average of those values.

8. In Table A3, the first column provides the number of the question as of wave III, and the second column details the exact question. Column 3 reports the weight of the question given to it in the construction of the indicator for the area to which it pertains. Column 4 describes the coding of the answers, and - where necessary - also gives a short explanation for the thinking behind the coding. Column

54. http://go.worldbank.org/SNUSW978P0

55. For example, for question 5.1 from the section on External Auditing and Information Disclosure Requirements, countries receive a score of ten if they answered "Yes" to the question "Is an external audit a compulsory obligation for banks?" and a score of zero if their answer was "No". Having a compulsory external audit is obviously a better guarantee of sound financial practices than having an internal one, or no compulsory audit at all.

56. Some arbitrary choices of scale were unavoidable in coding these questions. In each case, simplicity and comparability across countries were privileged. For instance, question 1.8 in the Entry Rules domain asks "Which of the following are legally required to be submitted before issuance of the banking license?", before mentioning eight possibly compulsory documents to be disclosed to the supervisory authority when applying for a license. As the total number of compulsory items is an indication of the amount of information available to the supervisor, and assuming that a better informed supervisor is preferable from a prudential point of view, the score was set equal to the number of requested items times 1.25 in order to normalise it between zero and ten. Countries in which the eight mentioned documents were compulsory therefore received a score of ten. In practice, the latter scale makes the simplifying assumption that all compulsory documents are equally important from a prudential perspective.

57. The exact coding is as follows: Fully Compliant/Implemented - 10, Broadly Compliant/Implemented 6.66, Largely Compliant/Implemented - 3.33, Not Compliant/Implemented - 0. 
5 singles out potentially competition-adverse regulations. The last three columns report whether a question figured in the survey for a given wave (indicating the number of a question when it differs from that in wave III).

9. The data set is complemented with information taken from the OECD Annual National Accounts database (GDP per capita), from the World Bank WDI database (PPP exchange rates, and GDP per capita for AC and EE5 countries), and from Pringle (2008) for the number of staff in supervisory agencies, and the number of banks. ${ }^{58}$

Table A3. Composition of the Indicators

A. Indicator for Capital Adequacy

\begin{tabular}{|c|c|c|c|c|c|c|c|}
\hline \multirow[t]{2}{*}{ ID } & \multirow[t]{2}{*}{ Question } & \multirow[t]{2}{*}{ Weight } & \multirow[t]{2}{*}{ Coding of data } & \multirow{2}{*}{$\begin{array}{l}\text { Adverse } \\
\text { impact on } \\
\text { competition }\end{array}$} & \multicolumn{3}{|c|}{ Availability } \\
\hline & & & & & $\mathrm{I}$ & II & III \\
\hline 3.1 & What is the minimum capital to asset ratio requirement? & 3 & $\begin{array}{l}\text { The higher the better: the score increases } \\
\text { proportionally between } 5 \text { and } 10 \text {, while countries } \\
\text { with a ratio of } 8 \% \text { get } 5 \text { and those above } 12 \% \text { get } \\
10\end{array}$ & & $x$ & $x$ & $x$ \\
\hline 3.2 & Does the minimum ratio vary as a function of an individual & 1 & Yes $=10$ & & $\mathrm{x}$ & $x$ & $\mathrm{x}$ \\
\hline 3.3 & Does the minimum ratio vary as a function of market risk? & 1 & Yes $=10$ & & $\mathrm{x}$ & $x$ & $x$ \\
\hline 3.3 .1 & Does the minimum ratio vary as a function of operational risk? & 1 & Yes $=10$ & & & & $\mathrm{x}$ \\
\hline 3.3 .2 & Is there a simple leverage ratio that is required? & 3 & Yes $=10$ & & & & $x$ \\
\hline 3.5 & Is subordinated debt allowable as part of regulatory capital? & 3 & Subordinated debt is not risk-free: $\mathrm{No}=10$ & & $\mathrm{x}$ & $\mathrm{x}$ & $\mathrm{x}$ \\
\hline 3.7 & What fraction of revaluation gains is allowed as part of capital? & 1 & $\begin{array}{l}\text { The lower the better. The fraction of revaluation } \\
\text { gains is normalized between } 0 \text { and } 10 \text { and } \\
\text { substracted to } 10 \text { to provide the score. }\end{array}$ & & $\begin{array}{c}x \\
3.6\end{array}$ & $x$ & $x$ \\
\hline \multirow[t]{4}{*}{3.9} & $\begin{array}{l}\text { Before minimum capital adequacy is determined, which of the } \\
\text { following are deducted from the book value of capital? }\end{array}$ & & All deductions are good: & & & & \\
\hline & 1. Market value of loan losses not realized in accounting & 2 & Yes $=10$ & & $x$ & $x$ & $\mathrm{x}$ \\
\hline & 2. Unrealized losses in securities portfolios? & 2 & Yes $=10$ & & $x$ & $x$ & $x$ \\
\hline & 3. Unrealized foreign exchange losses? & 2 & Yes $=10$ & & $x$ & $x$ & $x$ \\
\hline 11.3.1 & $\begin{array}{l}\text { Can the supervisory agency suspend the directors' decision to } \\
\text { distribute dividends? }\end{array}$ & 1 & $\begin{array}{l}\text { Supervisor should have this power in case of } \\
\text { necessity: } Y e s=10\end{array}$ & & $\mathrm{x}$ & $x$ & $\mathrm{x}$ \\
\hline
\end{tabular}

B. Indicator for Liquidity and Diversification

\begin{tabular}{|c|c|c|c|c|c|c|c|}
\hline \multirow[t]{2}{*}{ ID } & \multirow[t]{2}{*}{ Question } & \multirow[t]{2}{*}{ Weight } & \multirow[t]{2}{*}{ Coding of data } & \multirow{2}{*}{$\begin{array}{l}\text { Adverse } \\
\text { impact on } \\
\text { competition }\end{array}$} & \multicolumn{3}{|c|}{ Availability } \\
\hline & & & & & 1 & II & III \\
\hline 7.1.1 & Are banks limited in their lending to single or related borrowers? & 3 & $\begin{array}{l}\text { Some limitations would avoid conflicts of interest: } \\
\text { Yes }=10\end{array}$ & & & & $\mathrm{x}$ \\
\hline 7.1 .2 & Are banks limited in their sectoral concentration? & 2 & $\begin{array}{l}\text { Some limitations would ensure risk } \\
\text { diversification: } Y e s=10\end{array}$ & $\mathrm{x}$ & & & $\mathrm{x}$ \\
\hline 7.3 & $\begin{array}{l}\text { Are banks required to hold either liquidity reserves or any } \\
\text { deposits at the Central Bank? }\end{array}$ & 2 & Yes $=10$ & & $x$ & $x$ & $\mathrm{x}$ \\
\hline 7.4 & Do these reserves earn any interest? & 2 & Yes $=10$ & & $x$ & $x$ & $x$ \\
\hline 7.5 & $\begin{array}{l}\text { Are banks allowed to hold reserves in foreign denominated } \\
\text { currencies or other foreign denominated instruments? }\end{array}$ & 2 & $\begin{array}{l}\text { This would provide some protection against } \\
\text { contagion effects from currency crisis: } Y e s=10\end{array}$ & & & $\mathrm{x}$ & $x$ \\
\hline
\end{tabular}

58. Pringle, R. (ed.) (2008), "How Countries Supervise Their Banks, Insurers and Securities Markets", London: Central Banking Publications. 
ECO/WKP(2009)76

C. Indicator for Accounting and Provisioning

\begin{tabular}{|c|c|c|c|c|c|c|c|}
\hline \multirow[t]{2}{*}{ ID } & \multirow[t]{2}{*}{ Question } & \multirow[t]{2}{*}{ Weight } & \multirow[t]{2}{*}{ Coding of data } & \multirow{2}{*}{$\begin{array}{l}\text { Adverse } \\
\text { impact on } \\
\text { competition }\end{array}$} & \multicolumn{3}{|c|}{ Availability } \\
\hline & & & & & 1 & ॥ & III \\
\hline 3.10 & $\begin{array}{l}\text { Are accounting practices for banks in accordance with } \\
\text { International Accounting Standards (IAS)? }\end{array}$ & 2 & $\begin{array}{l}\text { It would be good for transparency: Yes }=5 \text {, and } \\
\text { among countries with a Yes those in accordance } \\
\text { with US Generally Accepted Accounting } \\
\text { Principles (GAAP) get a score of } 10 \text {. }\end{array}$ & & & $x$ & $\mathrm{x}$ \\
\hline 9.1 & Is there a formal definition of a "nonperforming loan" ? & 3 & Yes $=10$ & & $x$ & $x$ & $x$ \\
\hline 9.5 & $\begin{array}{l}\text { If a customer has multiple loans and one loan is classified as } \\
\text { non-performing, are the other loans automatically classified as } \\
\text { non-performing? }\end{array}$ & 3 & Yes $=10$ & & $\begin{array}{c}x \\
9.6\end{array}$ & $x$ & $x$ \\
\hline 9.8 & $\begin{array}{l}\text { Which of the following provisions are tax deductible? } \\
\text { 1. Specific provisions can be deducted } \\
\text { 2. General provisions can be deducted } \\
\text { 3. Provisions can not be deducted }\end{array}$ & 3 & $\begin{array}{l}\text { Deductions for general provisions will entail more } \\
\text { prudential capital. General }=10, \text { Specific }=5 .\end{array}$ & & & $x$ & $x$ \\
\hline 10.1 & $\begin{array}{l}\text { Does accrued, though unpaid, interest/principal enter the } \\
\text { income statement while the loan is still performing? }\end{array}$ & 1 & $\begin{array}{l}\text { It is more prudent that due payments are only } \\
\text { recorded as income once they have been } \\
\text { received: No }=10\end{array}$ & & $x$ & $x$ & $x$ \\
\hline 10.1 .1 & $\begin{array}{l}\text { Does accrued, though unpaid, interest/principal enter the } \\
\text { income statement while the loan is still non-performing? }\end{array}$ & 2 & $\begin{array}{l}\text { Same reason applies, especially if the loan is } \\
\text { already non-performing: No }=10\end{array}$ & & $x$ & $x$ & $x$ \\
\hline 10.4.1 & Are off-balance sheet items disclosed to the public? & 1 & Yes $=10$ & & $x$ & $x$ & $x$ \\
\hline 11.2 & $\begin{array}{l}\text { Can the supervisory agency order the bank's directors or } \\
\text { management to constitute provisions to cover actual or } \\
\text { potential losses? }\end{array}$ & 3 & $Y e s=10$ & & $x$ & $x$ & $x$ \\
\hline
\end{tabular}

D. Indicator for External Auditing and Information Disclosure

\begin{tabular}{|c|c|c|c|c|c|c|c|}
\hline \multirow[t]{2}{*}{ ID } & \multirow[t]{2}{*}{ Question } & \multirow[t]{2}{*}{ Weight } & \multirow[t]{2}{*}{ Coding of data } & \multirow{2}{*}{$\begin{array}{l}\text { Adverse } \\
\text { impact on } \\
\text { competition }\end{array}$} & \multicolumn{3}{|c|}{ Availability } \\
\hline & & & & & I & $\|$ & III \\
\hline 5.1 & Is an external audit a compulsory obligation for banks? & 3 & Yes $=10$ & & $\mathrm{x}$ & $x$ & $\mathrm{x}$ \\
\hline 5.1 .1 & $\begin{array}{l}\text { Are auditing practices for banks in accordance with } \\
\text { international auditing standards? }\end{array}$ & 2 & It conveys more transparency: $Y e s=10$ & & & & $\mathrm{x}$ \\
\hline 5.1 .2 & $\begin{array}{l}\text { Is it required by the regulators that bank audits be publicly } \\
\text { disclosed? }\end{array}$ & 1 & It conveys more transparency: $Y e s=10$ & & & & $\mathrm{x}$ \\
\hline 5.2 & $\begin{array}{l}\text { Are specific requirements for the extent or nature of the audit } \\
\text { spelled out? }\end{array}$ & 1 & Specific requirements are risk-based: $Y e s=10$ & & $\mathrm{x}$ & $x$ & $\mathrm{x}$ \\
\hline 5.3 & Are auditors licensed or certified? & 1 & Yes $=10$ & & $\mathrm{x}$ & $\mathrm{x}$ & $\mathrm{x}$ \\
\hline 5.4 & Do supervisors get a copy of the auditor's report? & 3 & Yes $=10$ & & $x$ & $x$ & $x$ \\
\hline 5.5 & $\begin{array}{l}\text { Does the supervisory agency have the right to meet with } \\
\text { external auditors to discuss their report without the approval of }\end{array}$ & 3 & Yes $=10$ & & $x$ & $x$ & $x$ \\
\hline 5.6 & $\begin{array}{l}\text { Are auditors required by law to communicate directly to the } \\
\text { supenisory agency any presumed involvement of bank directors } \\
\text { or senior managers in illicit activities, fraud, or insider abuse? }\end{array}$ & 2 & Yes $=10$ & & $\mathrm{x}$ & $\mathrm{x}$ & $\mathrm{x}$ \\
\hline 5.6 .1 & $\begin{array}{l}\text { Are external auditors legally required to report to the } \\
\text { superisory agency any other information discovered in an audit } \\
\text { that could jeopardize the health of a bank? }\end{array}$ & 3 & Yes $=10$ & & & & $\mathrm{x}$ \\
\hline 5.7 & $\begin{array}{l}\text { Can supervisors take legal action against external auditors for } \\
\text { negligence? }\end{array}$ & 2 & Yes $=10$ & & $\mathrm{x}$ & $\mathrm{x}$ & $\mathrm{x}$ \\
\hline 10.5 & $\begin{array}{l}\text { Must banks disclose their risk management procedures to the } \\
\text { public? }\end{array}$ & 1 & Yes $=10$ & $x$ & $\mathrm{x}$ & $\mathrm{x}$ & $\mathrm{x}$ \\
\hline 10.6 & $\begin{array}{l}\text { Are bank directors legally liable if information disclosed is } \\
\text { erroneous or misleading? }\end{array}$ & 2 & Yes $=10$ & & $\mathrm{x}$ & $\mathrm{x}$ & $\mathrm{x}$ \\
\hline 10.6.1 & What are the penalties, if applicable? & 2 & $\begin{array}{l}\text { Among penalties, prison is the most deterrent, } \\
\text { followed by fines: Prison }=10 \text {, Fines }=5 \text {. }\end{array}$ & & $x$ & $x$ & $\mathrm{x}$ \\
\hline 10.7 & Do regulations require credit ratings for commercial banks? & 1 & $\begin{array}{l}\text { Credit ratings convey some prudential } \\
\text { information: } Y e s=10\end{array}$ & & $\mathrm{x}$ & $\mathrm{x}$ & $\mathrm{x}$ \\
\hline
\end{tabular}


ECO/WKP(2009)76

E. Indicator for Entry and Ownership

\begin{tabular}{|c|c|c|c|c|c|c|c|}
\hline \multirow[t]{2}{*}{ ID } & \multirow[t]{2}{*}{ Question } & \multirow[t]{2}{*}{ Weight } & \multirow[t]{2}{*}{ Coding of data } & \multirow{2}{*}{$\begin{array}{l}\text { Adverse } \\
\text { impact on } \\
\text { competition }\end{array}$} & \multicolumn{3}{|c|}{ Availability } \\
\hline & & & & & 1 & II & III \\
\hline 1.1 & What body/agency grants commercial banking licenses? & 2 & $\begin{array}{l}\text { Independent regulator and central banks might } \\
\text { display more independence than agencies based } \\
\text { in a ministry: Regulator and Central Bank }=10 \text {, } \\
\text { Ministry = } 8\end{array}$ & & $\mathrm{x}$ & $\mathrm{x}$ & $x$ \\
\hline 1.1 .2 & $\begin{array}{l}\text { Is more than one license required (e.g., one for each banking } \\
\text { activity, such as commercial banking, securities operations, } \\
\text { insurance, etc.)? }\end{array}$ & 1 & $\begin{array}{l}\text { Specific licenses imply additional controls: Yes } \\
=10\end{array}$ & $\mathrm{x}$ & & $\mathrm{x}$ & $\mathrm{x}$ \\
\hline \multirow[t]{3}{*}{1.3} & What is the minimum capital entry requirement? & & All amounts are expressed in USD PPP & & & & \\
\hline & 1. For a domestic bank & 2 & $\begin{array}{l}\text { The score is equal to the normalized (between } 0 \\
\text { and 10) minimal capital capped at } 29.1 \mathrm{M} \text { USD } \\
\text { (percentile } 75 \text { of the distribution of minimal }\end{array}$ & $\mathrm{x}$ & & $x$ & $x$ \\
\hline & 2. For a subsidiary of a foreign bank & 1 & idem & $\mathrm{x}$ & & & $\mathrm{x}$ \\
\hline 1.4 & $\begin{array}{l}\text { Is it legally required that applicants submit information on the } \\
\text { source of funds to be used as capital? }\end{array}$ & 2 & Yes $=10$ & & $\mathrm{x}$ & $\mathrm{x}$ & $\mathrm{x}$ \\
\hline 1.5 & $\begin{array}{l}\text { Are the sources of funds to be used as capital verified by the } \\
\text { regulatory/supervisory authorities? }\end{array}$ & 2 & Yes $=10$ & & $x$ & $\mathrm{x}$ & $\mathrm{x}$ \\
\hline 1.6 & $\begin{array}{l}\text { Can the initial disbursement or subsequent injections of capital } \\
\text { be done with assets other than cash or government securities? }\end{array}$ & 1 & Other assets are riskier: $\mathrm{No}=10$ & $\mathrm{x}$ & $\mathrm{x}$ & $\mathrm{x}$ & $\mathrm{x}$ \\
\hline 1.7 & $\begin{array}{l}\text { Can initial disbursement of capital be done with borrowed } \\
\text { funds? }\end{array}$ & 1 & $\begin{array}{l}\text { Such possibility would sgnificantly increase } \\
\text { overall leverage in the economy: No }=10\end{array}$ & $\mathrm{x}$ & $\mathrm{x}$ & $\mathrm{x}$ & $\mathrm{x}$ \\
\hline \multirow[t]{8}{*}{1.8} & $\begin{array}{l}\text { Which of the following are legally required to be submitted } \\
\text { before issuance of the banking license? }\end{array}$ & 3 & $\begin{array}{l}\text { The more information, the better: Score }= \\
\text { number of requested items } \times 1.25\end{array}$ & $\mathrm{x}$ & $\mathrm{x}$ & $x$ & $\mathrm{x}$ \\
\hline & 1. Draft by laws? & & & & & & \\
\hline & 2. Intended organization chart? & & & & & & \\
\hline & 3. Financial projections for first three years? & & & & & & \\
\hline & 4. Financial information on main potential shareholders? & & & & & & \\
\hline & 5. Background/experience of future directors? & & & & & & \\
\hline & 6. Background/experience of future managers? & & & & & & \\
\hline & $\begin{array}{l}\text { 7. Sources of funds to be disbursed in the capitalization of new } \\
\text { bank? } \\
\text { 8. Market differentiation intended for the new bank? }\end{array}$ & & & & & & \\
\hline 2.2 & Can related parties own capital in a bank? & 1 & $\begin{array}{l}\text { This possibility would increase the risk of } \\
\text { collusion: No }=10\end{array}$ & $\mathrm{x}$ & $\mathrm{x}$ & $\mathrm{x}$ & $\mathrm{x}$ \\
\hline 2.2 .1 & $\begin{array}{l}\text { If yes, what are the maximum percentages associated with the } \\
\text { total ownership by a related party group (e.g., family, business } \\
\text { associates, etc.)? }\end{array}$ & 1 & $\begin{array}{l}\text { The lower this percentage, the better: Score }=0 \\
\text { if this percentage is smaller than } 10 \%, 5 \text { if it is } \\
\text { comprised between } 10 \% \text { and } 25 \%, 0 \text { otherwise. }\end{array}$ & $x$ & $\mathrm{x}$ & $x$ & $\mathrm{x}$ \\
\hline 4.1 & $\begin{array}{l}\text { What are the conditions under which banks can engage in } \\
\text { securities activities? }\end{array}$ & 2 & $\begin{array}{l}\text { The recent crisis has shown that banks shall be } \\
\text { very cautious with securities activities: } \\
\text { "Prohibited" = 10, "Restricted" = 5, "Permitted" = } \\
2.5 \text {, "Unrestricted" = } 0\end{array}$ & & $\mathrm{x}$ & $x$ & $\mathrm{x}$ \\
\hline 4.2 & $\begin{array}{l}\text { What are the conditions under which banks can engage in } \\
\text { insurance activities? }\end{array}$ & 2 & $\begin{array}{l}\text { Different financial activities should be somewhat } \\
\text { compartimented in order to avoid contagion } \\
\text { effects: "Prohibited" and "Restricted" = } 10, \\
\text { "Permitted" = 5, "Unrestricted" }=0\end{array}$ & & $\mathrm{x}$ & $x$ & $\mathrm{x}$ \\
\hline 4.3 & $\begin{array}{l}\text { What are the conditions under which banks can engage in real } \\
\text { estate activities? }\end{array}$ & 2 & $\begin{array}{l}\text { The recent crisis has shown that banks shall be } \\
\text { very cautious with real estate activities: } \\
\text { "Prohibited" = } 10 \text {, "Restricted" = } 5 \text {, "Permitted" = } \\
2.5, \text { "Unrestricted" = } 0\end{array}$ & & $\mathrm{x}$ & $x$ & $\mathrm{x}$ \\
\hline 4.4 & Can banks own voting shares in nonfinancial firms? & 2 & $\begin{array}{l}\text { This possibility would increase the risk of } \\
\text { collusion: "Prohibited" }=10, \text { "Restricted" }=2.5, \\
\text { "Permitted" and "Unrestricted" }=0\end{array}$ & & $x$ & $x$ & $\mathrm{x}$ \\
\hline 7.2 & Are banks prohibited from making loans abroad? & 1 & Making loans abroad is riskier: $Y e s=10$ & & $\mathrm{x}$ & $\mathrm{x}$ & $\mathrm{x}$ \\
\hline
\end{tabular}


ECO/WKP(2009)76

F. Indicator for Exit Rules and Disciplining Devices

\begin{tabular}{|c|c|c|c|c|c|c|c|}
\hline \multirow{2}{*}{$\begin{array}{r}\text { ID } \\
\text { (1) } \\
\end{array}$} & \multirow{2}{*}{$\begin{array}{l}\text { Question } \\
\text { (2) }\end{array}$} & \multirow{2}{*}{$\begin{array}{l}\text { Weight } \\
\text { (3) } \\
\end{array}$} & \multirow{2}{*}{$\begin{array}{l}\text { Coding of data } \\
\text { (4) } \\
\end{array}$} & \multirow{2}{*}{$\begin{array}{l}\text { Adverse } \\
\text { impact on } \\
\text { competition } \\
\quad(5) \\
\end{array}$} & \multicolumn{3}{|c|}{ Availability } \\
\hline & & & & & 1 & II & III \\
\hline 11.1 & $\begin{array}{l}\text { Are there any mechanisms of cease and desist-type orders, } \\
\text { whose infraction leads to the automatic imposition of civil and } \\
\text { penal sanctions on the banks directors and managers? }\end{array}$ & 1 & Yes $=10$ & & $x$ & $\mathrm{x}$ & $\mathrm{x}$ \\
\hline 11.3 .2 & $\begin{array}{l}\text { Can the supervisory agency suspend the directors' decision to } \\
\text { distribute bonuses? }\end{array}$ & 1 & Yes $=10$ & & $\mathrm{x}$ & $\mathrm{x}$ & $\mathrm{x}$ \\
\hline 11.3 .3 & $\begin{array}{l}\text { Can the supervisory agency suspend the directors' decision to } \\
\text { distribute management fees? }\end{array}$ & 1 & Yes $=10$ & & $\mathrm{x}$ & $\mathrm{x}$ & $\mathrm{x}$ \\
\hline 11.4 & Have any such actions been taken in the last 5 years? & 1 & $\begin{array}{l}\text { A positive answer indicates that the supervisor has } \\
\text { not only de jure but also de facto the possibility to } \\
\text { exert this right: Yes }=10\end{array}$ & & $\mathrm{x}$ & $\mathrm{x}$ & $\mathrm{x}$ \\
\hline 11.5 .1 & Is there a separate bank insolvency law? & 3 & $\begin{array}{l}\text { A separate bank insolvency law is typically more } \\
\text { accurate and quicker than a general one: Yes }=10\end{array}$ & & & & $\mathrm{x}$ \\
\hline \multirow[t]{6}{*}{11.6} & $\begin{array}{l}\text { Who can legally declare - such that this declaration supersedes } \\
\text { some of the rights of shareholders - that a bank is insolvent } \\
\text { among: }\end{array}$ & 1 & $\begin{array}{l}\text { Larger number of institutions with this right } \\
\text { increases probability that insolvent banks will be } \\
\text { bankrupted: }\end{array}$ & & $x$ & $\mathrm{x}$ & $\mathrm{x}$ \\
\hline & 1. Bank supervisor & & Score $=10$ for at least two positive answers, & & & & \\
\hline & 2. Court & & 5 for one positive answer, 0 otherwise & & & & \\
\hline & 3. Deposit insurance agency & & & & & & \\
\hline & 4. Bank restructuring or Asset Management Agency & & & & & & \\
\hline & 5. Other (please specify) & & & & & & \\
\hline \multirow[t]{5}{*}{11.7} & $\begin{array}{l}\text { According to the Banking Law, who has authority to intervene, } \\
\text { that is, suspend some or all ownership rights? } \\
\text { 1. Bank supervisor }\end{array}$ & 1 & $\begin{array}{l}\text { Score }=10 \text { for at least two positive answers, } 5 \text { for } \\
\text { one positive answer, } 0 \text { otherwise }\end{array}$ & & $x$ & $\mathrm{x}$ & $\mathrm{x}$ \\
\hline & 2. Court & & & & & & \\
\hline & 3. Deposit insurance agency & & & & & & \\
\hline & 4. Bank restructuring or Asset Management Agency & & & & & & \\
\hline & 5. Other (please specify) & & & & & & \\
\hline 11.8 & $\begin{array}{l}\text { Does the Banking Law establish predetermined levels of solvency } \\
\text { (capital or net worth) deterioration which forces automatic actions } \\
\text { (like intervention)? }\end{array}$ & 3 & $\begin{array}{l}\text { Automatic triggers are an important safeguard: } \\
\text { Yes }=10\end{array}$ & & $x$ & $\mathrm{x}$ & $\mathrm{x}$ \\
\hline \multirow[t]{6}{*}{11.9 .1} & $\begin{array}{l}\text { Regarding bank restructuring and reorganization, can the } \\
\text { following agencies supersede shareholder rights? }\end{array}$ & 1 & $\begin{array}{l}\text { Score }=10 \text { for at least two positive answers, } 5 \text { for } \\
\text { one positive answer, } 0 \text { otherwise }\end{array}$ & & $\mathrm{x}$ & $\mathrm{x}$ & $\mathrm{x}$ \\
\hline & 1. Bank supervisor & & & & & & \\
\hline & 2. Court & & & & & & \\
\hline & 3. Deposit insurance agency & & & & & & \\
\hline & 4. Bank restructuring or Asset Management Agency & & & & & & \\
\hline & 5. Other (please specify) & & & & & & \\
\hline \multirow[t]{5}{*}{ 11.9.2 } & $\begin{array}{l}\text { Regarding bank restructuring and reorganization, can the } \\
\text { following agencies remove and replace management? } \\
\text { 1. Bank supervisor }\end{array}$ & 1 & $\begin{array}{l}\text { Score }=10 \text { for at least two positive answers, } 5 \text { for } \\
\text { one positive answer, } 0 \text { otherwise }\end{array}$ & & $\mathrm{x}$ & $\mathrm{x}$ & $\mathrm{x}$ \\
\hline & 2. Court & & & & & & \\
\hline & 3. Deposit insurance agency & & & & & & \\
\hline & 4. Bank restructuring or Asset Management Agency & & & & & & \\
\hline & 5. Other (please specify) & & & & & & \\
\hline \multirow[t]{5}{*}{11.9 .3} & $\begin{array}{l}\text { Regarding bank restructuring and reorganization, can the } \\
\text { following agencies remove and replace directors? } \\
\text { 1. Bank supervisor }\end{array}$ & 1 & $\begin{array}{l}\text { Score }=10 \text { for at least two positive answers, } 5 \text { for } \\
\text { one positive answer, } 0 \text { otherwise }\end{array}$ & & $\mathrm{x}$ & $\mathrm{x}$ & $\mathrm{x}$ \\
\hline & 2. Court & & & & & & \\
\hline & 3. Deposit insurance agency & & & & & & \\
\hline & 4. Bank restructuring or Asset Management Agency & & & & & & \\
\hline & 5. Other (please specify) & & & & & & \\
\hline 11.12 & $\begin{array}{l}\text { Is court approval required for supervisory actions, such as } \\
\text { superceding shareholder rights, removing and replacing } \\
\text { management, removing and replacing director, or license } \\
\text { revocation? }\end{array}$ & 1 & $\begin{array}{l}\text { Court approval may considerably lengthen } \\
\text { supervisory action: } \mathrm{No}=10\end{array}$ & & & $\mathrm{x}$ & $\mathrm{x}$ \\
\hline 11.14 & $\begin{array}{l}\text { Can the bank shareholders appeal to the court against a decision } \\
\text { of the bank supervisor? }\end{array}$ & 1 & $\begin{array}{l}\text { Appeal to the court may considerably lengthen } \\
\text { supervisory action: } \mathrm{No}=10\end{array}$ & & & $\mathrm{x}$ & $\mathrm{x}$ \\
\hline
\end{tabular}


ECO/WKP(2009)76

G. Indicator for Depositor Protection

\begin{tabular}{|c|c|c|c|c|c|c|c|}
\hline \multirow{2}{*}{ ID } & \multirow{2}{*}{$\begin{array}{l}\text { Question } \\
\text { (2) }\end{array}$} & \multirow{2}{*}{$\begin{array}{r}\text { Weight } \\
\text { (3) } \\
\end{array}$} & \multirow{2}{*}{$\begin{array}{l}\text { Coding of data } \\
\text { (4) }\end{array}$} & \multirow{2}{*}{$\begin{array}{l}\text { Adverse } \\
\text { impact on } \\
\text { competition } \\
\quad(5) \\
\end{array}$} & \multicolumn{3}{|c|}{ Availability } \\
\hline & & & & & 1 & II & III \\
\hline 3.8 .1 & $\begin{array}{l}\text { What fraction of the banking system's assets is in banks that are } \\
50 \% \text { or more government owned as of yearend } 2005 ?\end{array}$ & 1 & $\begin{array}{l}\text { Government-owned institutions are less likely to } \\
\text { default on deposits: the score is equal to the } \\
\text { normalised fraction (between } 0 \text { and 10) of } \\
\text { banking's assets, capped at } 18.8 \% \text { (percentile } 75 \\
\text { of the distribution of the government-owned } \\
\text { fraction) }\end{array}$ & $x$ & $\begin{array}{c}x \\
3.7\end{array}$ & $\mathrm{x}$ & $x$ \\
\hline 3.12 .1 & $\begin{array}{l}\text { What fraction of the banking systems' deposits are in banks that } \\
\text { are } 50 \% \text { or more government owned as of yearend } 2005 ?\end{array}$ & 2 & $\begin{array}{l}\text { Government-owned institutions are less likely to } \\
\text { default on deposits: the score is equal to the } \\
\text { normalised fraction (between } 0 \text { and 10) of } \\
\text { banking's assets, capped at } 18.8 \% \text { (percentile } 75 \\
\text { of the distribution of the government-owned } \\
\text { fraction) }\end{array}$ & $x$ & & & $x$ \\
\hline 3.13 .1 & $\begin{array}{l}\text { What fraction of the banking systems loans are in banks that are } \\
50 \% \text { or more government owned as of yearend } 2005 ?\end{array}$ & 1 & $\begin{array}{l}\text { Government-owned institutions are less likely to } \\
\text { default on deposits: the score is equal to the } \\
\text { normalised fraction (between } 0 \text { and 10) of } \\
\text { banking's assets, capped at } 18.8 \% \text { (percentile } 75 \\
\text { of the distribution of the government-owned } \\
\text { fraction) }\end{array}$ & $x$ & & & $x$ \\
\hline 8.1 & Is there an explicit deposit insurance protection system? & 3 & $\begin{array}{l}\text { Yes }=10 . \text { For all countries answering "No" (AUS, } \\
\mathrm{CHN} \text {, ISR, NZL, RSA) this question is coded as } 0 \text {, } \\
\text { as are questions } 8.1 .2,8.1 .3,8.1 .5 .2,8.1 .7 \text {, } \\
8.1 .10,8.1 .11 \text { and } 8.6 \text {. }\end{array}$ & & $\mathrm{x}$ & $\mathrm{x}$ & $\mathrm{x}$ \\
\hline 8.1 .2 & Are premia collected regularly (ex ante)? & 2 & $\begin{array}{l}\text { Collecting premia exclusively ex-ante is more } \\
\text { prudent: Score }=10 \text { if premia are collected ex- } \\
\text { ante, } 0 \text { if collected ex-post, } 5 \text { if both. }\end{array}$ & & & $\mathrm{x}$ & $x$ \\
\hline 8.1 .3 & $\begin{array}{l}\text { Do deposit insurance fees charged to banks vary based on some } \\
\text { assessment of risk? }\end{array}$ & 3 & $\begin{array}{l}\text { Risk-varying fees can be a disciplining device } \\
\text { against overly strong risk-taking: } Y e s=10\end{array}$ & & & $\mathrm{x}$ & $x$ \\
\hline 8.1.5.2 & What is the deposit insurance limit per account? & 3 & $\begin{array}{l}\text { The deposit insurance limit is converted in USD } \\
\text { (2005) and divided by GDP per capita (2005), } \\
\text { providing a ratio. This ratio is then capped at its } \\
75 \text { th percentile and normalized between } 0 \text { and } 10 \\
\text { to provide the score. }\end{array}$ & & $\begin{array}{c}x \\
8.1 .3\end{array}$ & $\mathrm{x}$ & $\mathrm{x}$ \\
\hline 8.1 .7 & $\begin{array}{l}\text { Is there formal coinsurance, that is, are depositors explicitly } \\
\text { insured for less than } 100 \% \text { of their deposits? }\end{array}$ & 3 & $\begin{array}{l}\text { Co-insurance increases the risk of bank-runs: } \\
\text { No }=10\end{array}$ & & $\begin{array}{c}x \\
8.2\end{array}$ & $\mathrm{x}$ & $\mathrm{x}$ \\
\hline 8.1 .9 & Are interbank deposits covered? & 1 & $\begin{array}{l}\text { In normal times, covering interbank deposits would } \\
\text { put unnecessary burden on deposit insurance: } \\
\text { No }=10\end{array}$ & & & $x$ & $\mathrm{x}$ \\
\hline 8.1 .10 & $\begin{array}{l}\text { Does the deposit insurance authority make the decision to } \\
\text { intervene in a bank? }\end{array}$ & 1 & Yes $=10$ & & $\begin{array}{c}x \\
8.1 .5\end{array}$ & $\mathrm{x}$ & $x$ \\
\hline 8.1 .11 & $\begin{array}{l}\text { Does the deposit insurance authority by itself have the legal } \\
\text { power to cancel or revoke deposit insurance for any participating } \\
\text { bank? }\end{array}$ & 2 & $\begin{array}{l}\text { In order to be credible, deposit insurance should } \\
\text { not be revocable: No }=10\end{array}$ & & & $\mathrm{x}$ & $\mathrm{x}$ \\
\hline 8.6 & $\begin{array}{l}\text { Can the deposit insurance agency/fund take legal action for } \\
\text { violations against laws, regulations, and bylaws (of the deposit } \\
\text { insurance agency) against bank directors or other bank officials? }\end{array}$ & 2 & Yes $=10$ & & $x$ & $x$ & $x$ \\
\hline
\end{tabular}


ECO/WKP(2009)76

H. Indicator for Authority of Supervisor

\begin{tabular}{|c|c|c|c|c|c|c|c|}
\hline \multirow[t]{2}{*}{ ID } & \multirow[t]{2}{*}{ Question } & \multirow[t]{2}{*}{ Weight } & \multirow[t]{2}{*}{ Coding of data } & \multirow{2}{*}{$\begin{array}{l}\text { Adverse } \\
\text { impact on } \\
\text { competition }\end{array}$} & \multicolumn{3}{|c|}{ Availability } \\
\hline & & & & & 1 & ॥ & III \\
\hline 6.1 & $\begin{array}{l}\text { Can the supervisory authority force a bank to change its } \\
\text { internal organizational structure? }\end{array}$ & 3 & Yes $=10$ & & $x$ & $x$ & $\mathrm{x}$ \\
\hline 12.1 .3 & $\begin{array}{l}\text { Do Multiple Bank Supervisory Agencies/Superintendencies } \\
\text { supervise banks? }\end{array}$ & 2 & $\begin{array}{l}\text { A system of multiple supervision creates } \\
\text { important coordination problems: } \mathrm{No}=10\end{array}$ & & $\begin{array}{c}x \\
12.1 .1\end{array}$ & $\begin{array}{c}x \\
12.1 .1\end{array}$ & $x$ \\
\hline 12.1.4 & $\begin{array}{l}\text { Is there a single financial supervisory agency for all of the main } \\
\text { financial institutions (insurance companies, contractual savings } \\
\text { institutions, savings banks)? If yes, what is its name? }\end{array}$ & 1 & $\begin{array}{l}\text { Yes }=10 . \text { This is not thought to take a stance of } \\
\text { the desirability of having an integrated financial } \\
\text { regulator, but simply meant to capture that larger } \\
\text { institutions are less at risk of being unduly } \\
\text { influenced by particular interests. }\end{array}$ & & & $\begin{array}{c}x \\
12.1 .2\end{array}$ & $x$ \\
\hline 12.1 .5 & $\begin{array}{l}\text { Is there a single financial supervisory agency for all of the } \\
\text { activities in which commercial banks are allowed to do }\end{array}$ & 1 & Yes $=10$. See comment above (12.1.4). & & & & $x$ \\
\hline 12.2 .3 & $\begin{array}{l}\text { Can the head of the supervisory agency can be removed by: } \\
\text { 1. the decision of the head of government (e.g. President, } \\
\text { 2. the decision of the Finance Minister or other cabinet level } \\
\text { 3. a simple majority of a legislative body (Parliament or } \\
\text { 4. a supermajority (e.g, } 60 \%, 75 \% \text { ) of a legislative body } \\
\text { 5. other }\end{array}$ & 2 & $\begin{array}{l}\text { The head of the agency should be as } \\
\text { as possible. Countries get } 10 \text { if they have } \\
\text { in each of the } 5 \text { items, } 0 \text { otherwise. }\end{array}$ & & $\begin{array}{c}x \\
12.2 .2\end{array}$ & $x$ & $x$ \\
\hline 12.4 & How many professional bank supervisors are there in total? & 2 & $\begin{array}{l}\text { Total staff of supervisory agencies are divided by } \\
\text { the number of banks to provide a ratio. This ratio } \\
\text { is capped at its } 75 \text { th percentile and normalized } \\
\text { between } 0 \text { and } 10 \text { to provide the score. }\end{array}$ & & $x$ & $x$ & $x$ \\
\hline 12.5 & $\begin{array}{l}\text { How many onsite examinations per bank were performed in the } \\
\text { last five years? }\end{array}$ & 2 & $\begin{array}{l}\text { All countries receive a score of } 10 \text { except NZL } \\
\text { that reports } 0 \text { onsite examination and receives a } \\
\text { score of } 0 .\end{array}$ & & $\mathrm{x}$ & $x$ & $x$ \\
\hline 12.6 & $\begin{array}{l}\text { What is the total budget for supervision in local currency or } \\
\text { dollars (please specify) in 2005? }\end{array}$ & 2 & $\begin{array}{l}\text { The budget is converted in USD then divided by } \\
\text { the number of banks as well as GDP per capita. } \\
\text { The resulting ratio is then capped at its } 75 \text { th } \\
\text { percentile and renormalized between } 0 \text { and } 10 \text { to } \\
\text { provide the score. }\end{array}$ & & $x$ & $x$ & $x$ \\
\hline 12.7 & $\begin{array}{l}\text { How frequently are onsite inspections conducted in large and } \\
\text { medium size banks? }\end{array}$ & 2 & $\begin{array}{l}\text { "Annually" = 10, "Every two year" = 5, other } \\
\text { countries get } 0 .\end{array}$ & & $x$ & $x$ & $x$ \\
\hline 12.8 & $\begin{array}{l}\text { How many of the total bank supervisors have more than } 10 \\
\text { years of experience in bank supervision? }\end{array}$ & 1 & $\begin{array}{l}\text { Score }=10 \text { if at least } 40 \% \text { of total staff has more } \\
\text { than } 10 \text { years of experience, } 5 \text { if the latter } \\
\text { proportion is comprised between } 20 \% \text { and } 40 \% \text {, }\end{array}$ & & $x$ & $x$ & $x$ \\
\hline 12.9 & $\begin{array}{l}\text { If an infraction of any prudential regulation is found in the course } \\
\text { of supervision, must it be reported? }\end{array}$ & 2 & Yes $=10$ & & $\begin{array}{c}x \\
12.10\end{array}$ & $x$ & $x$ \\
\hline 12.9.1 & $\begin{array}{l}\text { Are there mandatory actions that the supervisor must take in } \\
\text { these cases? }\end{array}$ & 2 & Yes $=10$ & & $\begin{array}{c}x \\
12.11\end{array}$ & $x$ & $x$ \\
\hline 12.10 & $\begin{array}{l}\text { Can individual supervisory staff be held personally liable for } \\
\text { damages to a bank caused by their actions or omissions } \\
\text { committed in the good faith exercise of their duties? }\end{array}$ & 3 & $\begin{array}{l}\text { The supervisory staff should be legally protected: } \\
\text { No }=10\end{array}$ & & $\begin{array}{c}x \\
12.14\end{array}$ & $x$ & $x$ \\
\hline 12.10.1 & $\begin{array}{l}\text { Can the supervisory agency be held liable for damages to a } \\
\text { bank caused by its actions? }\end{array}$ & 2 & $\begin{array}{l}\text { The supervisory agency should be legally } \\
\text { protected: No = } 11\end{array}$ & & & & $x$ \\
\hline
\end{tabular}

Note: In the last three columns, numbers in small font size indicate the number of the question in the relevant wave of the questionnaire when it differs from that in wave III. 


\section{A1.3 Robustness analysis of indicators}

10. This section examines the robustness of the banking regulation indicators, both with respect to missing information and the weighting of underlying individual regulations.

\section{Robustness analysis with respect to missing information}

11. With banking regulation indicators being constructed from detailed information, the problem of missing information arises. There are two categories of missing information: data for a certain question may not be available for a country (a missing value), or a country may have answered that the question is not relevant in its specific case (a "non applicable"). In the following, the term "missing data" will refer to both missing values and non-applicable cases. The retained database (mainly based on information from the third wave of the World Bank banking regulation survey which has subsequently been verified by OECD and AC countries) provides information for all OECD, AC and EE5 countries. As some questions are divided into several sub-questions, there are in fact hundred questions/sub-questions in the database, and hence a total of 4000 observation points. Table A4 summarises the incidence of missing data, both for the total sample, and by area of banking regulation. It displays the total number of observations, as well as the total number of missing data points. It shows clearly that missing data are rare: they represent only $1.2 \%$ of total observations, with missing values accounting by far for the largest part $(1.1 \%$ of total observations). Seven of the eight areas display very little missing information. Only the area indicator measuring the strength of the supervisory authority has a somewhat higher proportion of missing data $(5.4 \%)$.

Table A4. Descriptive Analysis of Missing Data

\begin{tabular}{lccc}
\hline & Total number & \multicolumn{2}{c}{ Total missing data } \\
\cline { 3 - 4 } & of observations & Total & $\begin{array}{c}\text { Share } \\
\text { (in percent) }\end{array}$ \\
\hline Overall & 4000 & 47 & 1.2 \\
By area & & & \\
Capital Requirements & & 4 & 0.9 \\
Liquidity and Diversification Requirements & 440 & 1 & 0.5 \\
Accounting and Provisioning Requirements & 200 & 4 & 1.3 \\
External Auditing and Information Disclosure Requirements & 320 & 4 & 0.7 \\
Entry Rules and Ownership Structures & 560 & 0 & 0 \\
Exit Rules and Disciplining Devices & 920 & 2 & 0.4 \\
Depositor Protection & 520 & 2 & 0.4 \\
Strength of Supervisory Authority & 480 & 30 & 5.4 \\
\hline
\end{tabular}

12. Figure A4 shows the number of missing data by country. Whether missing data are concentrated among certain countries is important for evaluating the scope for potential biases in the construction of the indicators. Out of forty countries, there are twenty countries with a complete set of observations, twelve countries with one missing value, and eight with two or more missing observations. The highest number of missing data is eight (for China), which amounts to $8.2 \%$ of total observations for this country. There is no significant correlation between any BPR indicator and the number of missing data by country. 
Figure A4. Frequency of Missing Data by Country

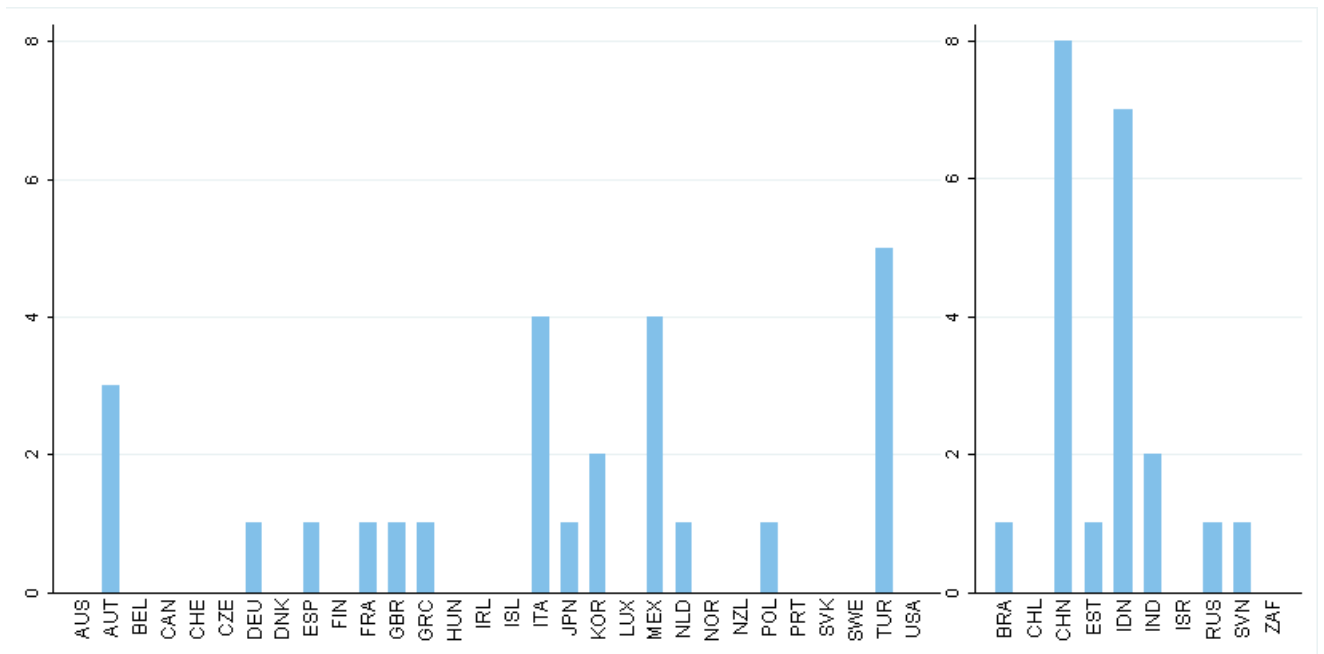

13. To check for the robustness of the indicators, the influence of missing data on the ranking of countries is examined along the eight dimensions of banking regulation. For this purpose, a Monte-Carlo experiment was conducted, in which all missing data were replaced by random values drawn from a uniform distribution over the interval $[0 ; 10]$. This operation was replicated five hundred times. ${ }^{59}$ For each country and each BPR indicator, this procedure resulted in a distribution of five hundred scores, and a corresponding distribution of five hundred rankings deduced from cross-country comparisons. Note that even if a given country has no missing information, its rank could still be modified by neighbouring countries with missing data. Hence, at least potentially, each country should have a non-trivial distribution of ranks in this experiment.

14. Figure A5 reports the average standard error of the rank distribution for each BPR indicator. With a probability of more than $95 \%$, shifts in a country's rank will be lower than twice the standard deviation of ranks. In practice, seven areas of banking regulation have an average standard deviation smaller than or close to 0.5 , implying that with a very high likelihood, missing data would at maximum entail an upward or downward shift by one rank. Similarly, with a very high likelihood, the maximum shift of ranks for the indicator measuring the strength of the supervisor - which is most affected by missing data - would be three. This implies that missing data do not have a relevant impact on the indicators, with the possible exception of the indicator measuring the strength of the supervisor.

59. In practice, similar results were obtained with only fifty iterations of the algorithm. 
Figure A5. Standard Deviation of the Distribution of Ranks by Country

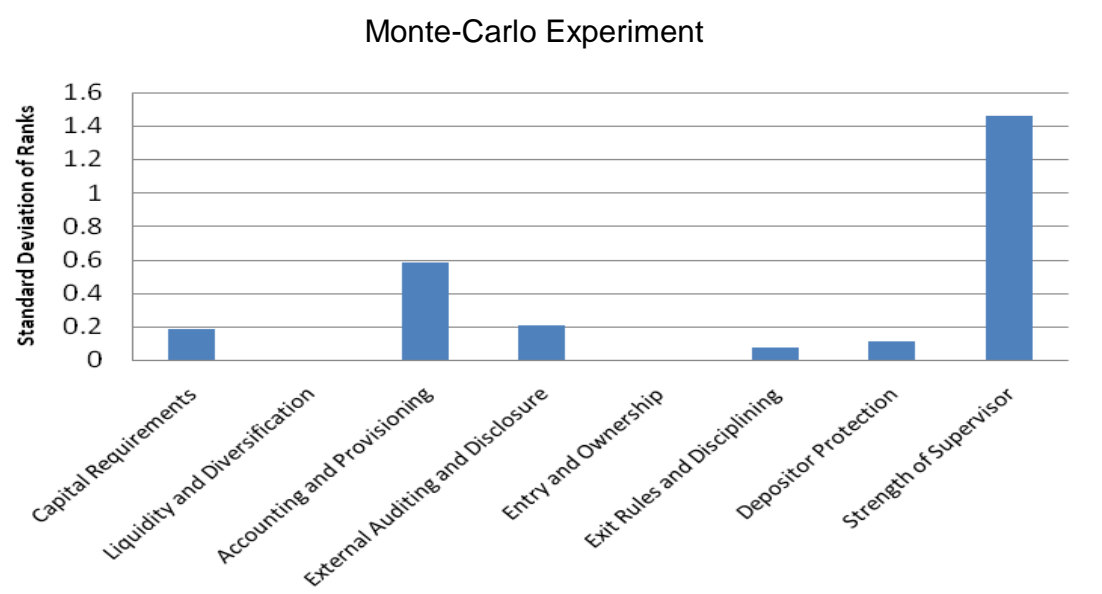

15. Examining for each country how the indicator measuring the strength of the supervisor could be affected by missing data shows that, while the indicator remains relatively stable for most countries, it could be substantially affected for Austria, Mexico, Turkey, China, Indonesia and Slovenia (Figure A6). For these countries the standard deviation of their distribution of ranks exceeds three, which represents a potential change of six ranks. This, however, does not change the finding that the impact of missing data is generally negligible.

Figure A6. Standard Deviation of Ranks for Index of Strength of Supervisor

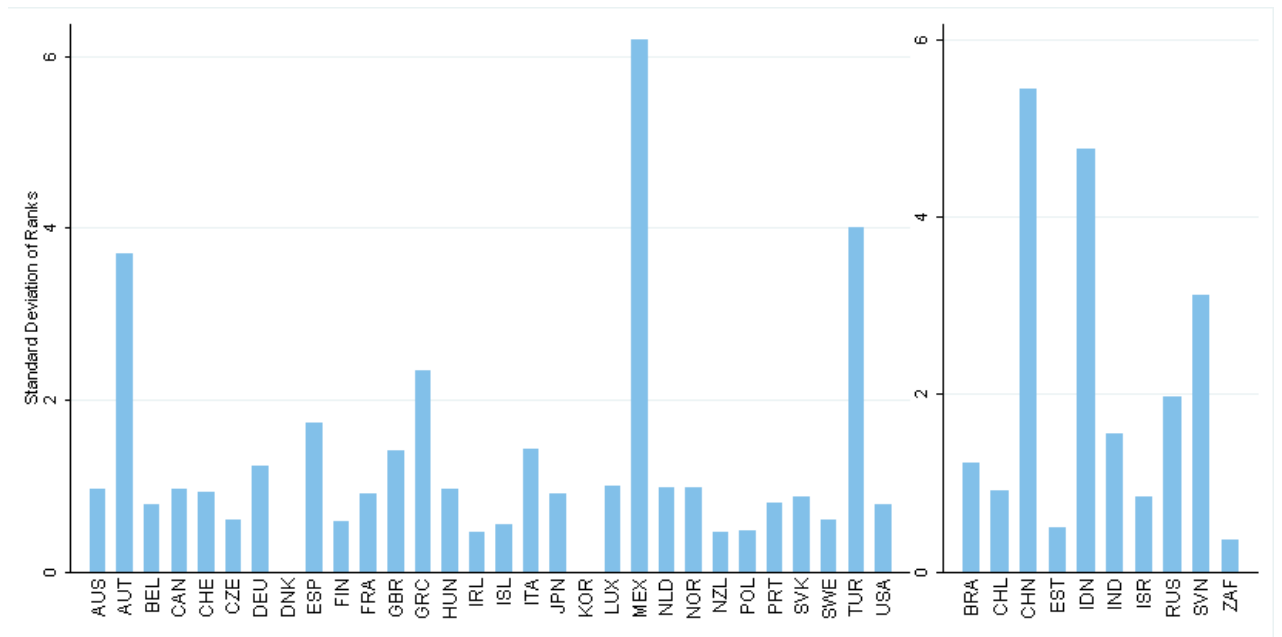

Robustness analysis of indicators with respect to different weights of underlying questions

16. As the banking indicators are compiled from numerous data points, an important element of the construction of the eight banking indicators is the weight to be given to each individual regulation used in the exercise. Based on expert knowledge and judgment, a benchmark set of weights has been constructed (as described in Table A3), with the chosen weights (low $=1$, normal $=2$, high $=3$ ) primarily reflecting the perceived importance of an individual regulation for the strength of the regulatory stance in the respective area. Even though each weight was carefully chosen, such an exercise remains subjective by definition, and assessing the degree to which a country's ranking is robust to changes in weights is a legitimate concern. 
17. Using Monte Carlo simulations with a newly developed modified random weights procedure, it is possible to determine for each indicator whether two countries' indicator values are significantly different. ${ }^{60}$ Based on this procedure roughly half of all possible pair-wise cross-country comparisons of regulatory stances are found to be highly robust to (potentially extreme) changes in the weighting scheme. This means that, on average, the value of any indicator for any OECD country is statistically different from that of 15 other OECD countries.

\section{Box A1. Testing for Indicator Robustness to Different Weighting Schemes}

One possibility to test the robustness of indicators to different weighting schemes is a "random weights" procedure. This methodology proceeds as follows: for each specific regulation included in a specific BPR indicator, a weight is drawn from a sample of $\{0,1,2,3\}$ with equal probabilities. This choice of sample is conservative insofar as it not only acknowledges that different individual regulations might have a different importance for the strength of the regulatory stance, but also that an individual regulation might not be relevant at all (zero weight). A BPR indicator resulting from a particular set of weights is calculated as the weighted sum of the individual regulations' scores. Repeating the Monte-Carlo procedure a large number of times leads to a distribution of possible values of the eight BPR indicators under uncertainty over the optimal weighting structure of underlying individual regulations. These distributions allow for comparisons across countries, and for testing whether differences in scores are significant.

The described random weights framework is, however, extreme with respect to the uncertainty stemming from the underlying weighting scheme since it requires that the score of country A obtained with a given set of weights must be smaller than the score of country B using another (completely different) set of weights (at a given confidence level). Such a requirement appears unnecessarily strong. An alternative criterion would be to require that under the same weighting scheme, whatever it may be, the score of country A shall be smaller than that of country B (at a given confidence level). The second criterion is less demanding because any particular weighting scheme may shift countries' scores in the same direction. Put differently, the second criterion can take into account the cross-country correlation of indicators arising from a common set of weights, whereas the first criterion treats questions' weights - and hence countries' scores - as independent variables.

In practice, the second criterion can be easily implemented. At each iteration of the Monte-Carlo algorithm described above, the resulting indicators are compared for any pair of countries, given that scores have been calculated under the same random weighting scheme. After a high number of iterations it is then possible to count how many times the score of a given country has been lower than that of another country, hence assessing all pair-wise order relationships using the same set of weights to compare countries. For the sake of comparison, the first criterion is also implemented by of counting the number of times that countries have been statistically different under independent drawings of weights.

18. When testing for indicator robustness with the two methods outlined in Box A1, the first criterion - as expected - turns out to be excessively demanding, ${ }^{61}$ but use of the second criterion provides satisfactory results. Figure A7 reports the percentage of times that each criterion leads to a statistically significant difference in scores among all possible cross-country comparisons for each indicator. As it turns

60. The original random weights procedure calculates confidence intervals for indicator values. Here, for a given draw of weights, indicator values for countries are compared in a pair-wise fashion. If in more than $90 \%$ of cases one of the countries (say country A) has a higher value, it is said that the indicator value for country A is significantly higher than the indicator value for country B. Such a pair-wise comparison is calculated for each possible country pair, with the results being reported in a matrix.

61. This procedure leads to a fair amount of uncertainty and a large number of undistinguishable countries. Indeed, the underlying random weights have substantial influence on the value of the BPR indicators (on average, they have a coefficient of variation of about 0.15 , entailing a confidence interval of plus or minus thirty percent of the average score), and as a result country distributions of scores have a large variance and often intersect. Thus, it is fairly difficult to obtain significant differences between countries on a $90 \%$ confidence level. 
out, about $50 \%$ of pair-wise country comparisons are statistically significant with the second criterion (versus $15 \%$ for the first criterion). For the indicators measuring, respectively, capital requirements and exit rules, this percentage reaches $60 \%$. The index capturing liquidity and diversification requirements, which is based on relatively fewer individual regulations, identifies a minimum of $30 \%$ of significant pairwise relationships.

Figure A7. Percentage of Statistically Different Country Scores

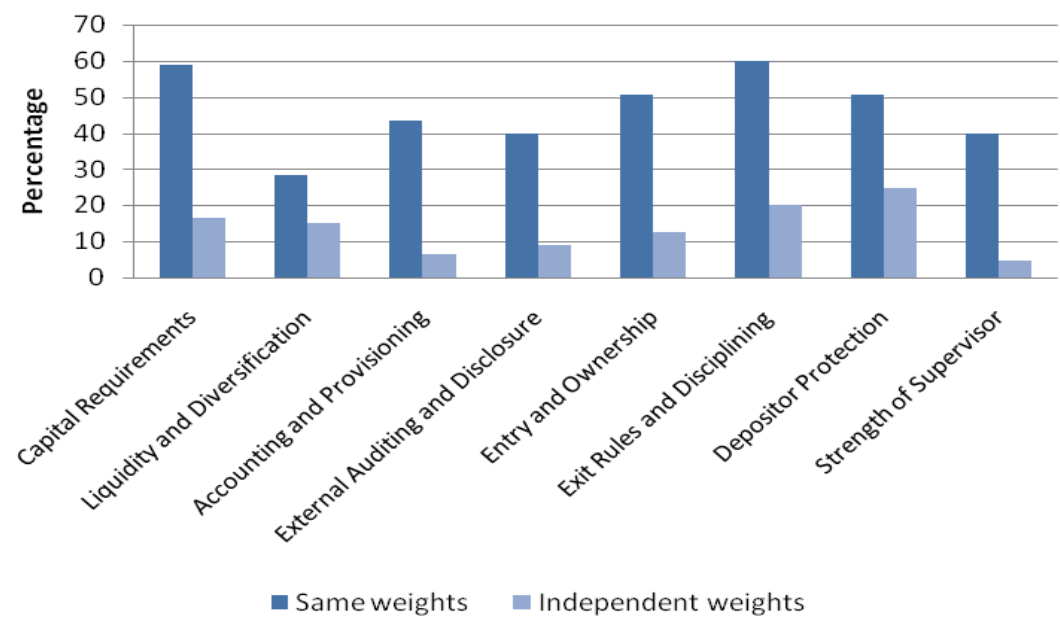

19. As an illustration of the statistical power of the second criterion, Table A5 displays the results of the Monte-Carlo experiment for a specific example, the indicator measuring the strength of capital requirements. Results are presented in the form of a matrix, whose element a(i,j) represents the percentage of times that the country in row $i$ had a smaller index of capital requirements than the country in column $j$. This matrix presents a symmetric pattern since $a(i, j)+a(j, i)=100$. It reads in the following way: if $a(i, j)$ is greater than 95 , it means that in $95 \%$ of cases country $i$ had a smaller score than country $j$, hence that it displays a significantly lower score on the prudential regulation indicator measuring capital requirements. In the table such cells are darkly shaded, with cases corresponding to a $90 \%$ confidence level more lightly shaded. Countries are simply classified by increasing order of their average indicator value. It turns out that there are a large number of statistically significant pair-wise order relationships: In total these amount to 440 for the set of OECD countries at the $95 \%$ level, and 512 at the $90 \%$ confidence level. At the $90 \%$ confidence level, this represents about $512 /(30 \times 29)=59 \%$ of the total number of possible order relationships within the OECD sample ${ }^{62}$. In comparison, with the first criterion at best $17 \%$ of possible order relationships are identified as statistically significant. Put differently, in the presented example the second criterion achieves to distinguish 3.5 times more statistically significant order relationships than the first criterion.

20. The ability of the second criterion to distinguish more rank order relationships does not mean, however, that it is preferable under all circumstances. The key difference between the two methodologies is that the first one assumes independence between weights of underlying questions across countries, while the second one assumes that all countries should be evaluated with the same set of weights. If it was the case that weighting structures should be country specific, then the first criterion would be more appropriate. If, however, it is thought that regulations should have roughly comparable effects in different countries, or simply that BPR indicators should be calculated on a consistent set of individual regulations and weights, then the second methodology would be more suitable. As noted above, for banking indicators as presented here the second methodology appears to be more appropriate.

62. In a sample of $n$ countries, there are at maximum $n *(n-1)$ order relationships, so 870 in the sample of 30 OECD countries. 
Table A5. Significance of Differences between Country Scores in Capital Requirements Index

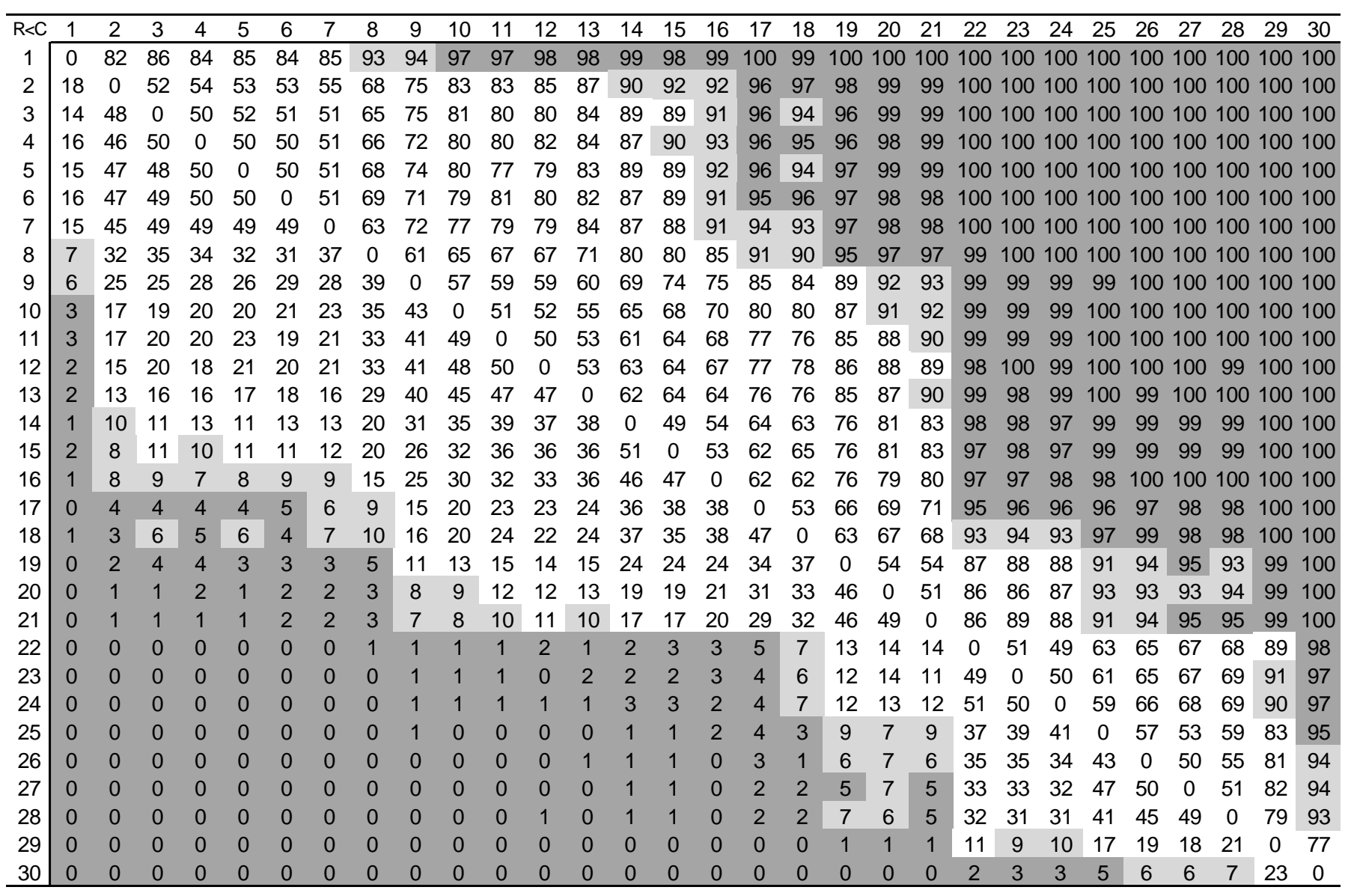

The above table reports the percentage of times that the country in row $\mathrm{x}$ had a lower score in the banking regulation indicator than the country in column $y$ in a Monte-Carlo experiment. Dark shade corresponds to a $95 \%$ confidence level and lighter shade to a $90 \%$ confidence interval. The symmetric relationship - the indicator value of the country in row $\times$ being higher than the score of the country in column $y-$ is correspondingly shaded. 


\section{A2. Presentation of insurance regulation indicators}

21. Figure A8 shows the prudential regulation indicator for insurance (with higher values indicating stricter compliance with regulatory recommendations).

Figure A8. Prudential Regulation Indicator for Insurance

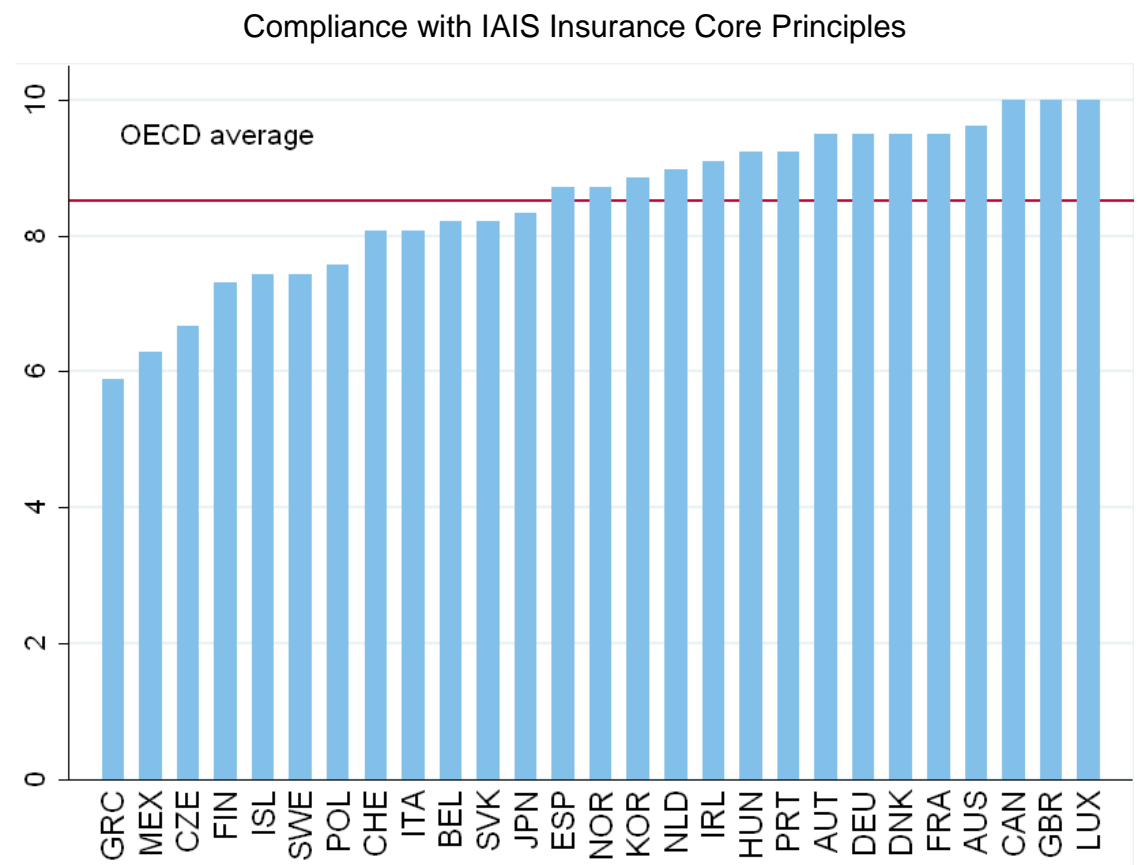

Note: The chart is restricted to those OECD countries for which the necessary underlying information has been published in the framework of a FSAP report.

\section{A3. Additional information for Section 3}

\section{Cross-country variation in Banking Share Price Declines and the Fiscal Cost of Rescue Packages}

22. Banks have been affected by the recent crisis in many different ways, but two features that are most likely to be remembered for some time are the massive destruction of banking equity value and the substantial amounts of public funds that governments have put up to banks' rescue. As can be seen from Figures A9 and A10, countries differ significantly with respect to both the incidence of share price declines of banks and the size of the rescue packages. 


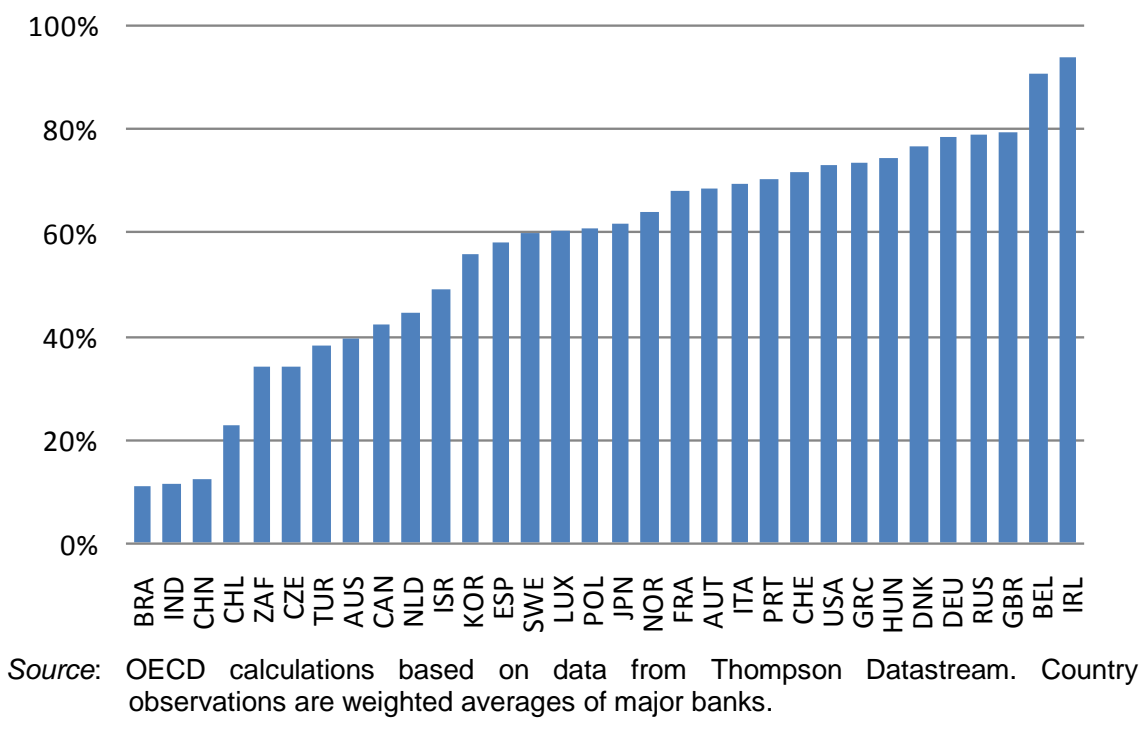

Figure A10. Net Expected Cost from Financial Sector Support Measures

Percentage of GDP

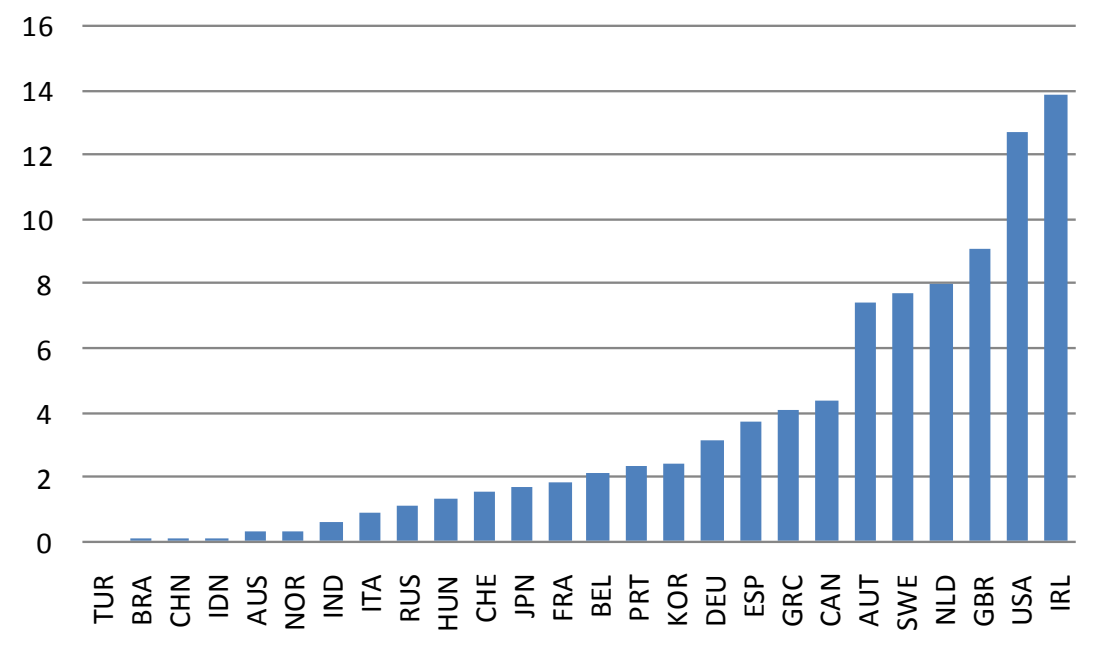

Source: IMF estimations

\section{Robustness check of the results presented in Table 1}

23. As robustness check, a more parsimonious specification has been estimated, in which binary variables indicating the lowest quartile of countries with respect to each BPR indicator were introduced into the regressions instead of the indicators themselves. This amounts to a mere test of whether banks in countries with the least stringent prudential rules in a given area experienced different share price developments than the rest of the sample. The motivation for this exercise is to account for a possible presence of measurement errors. Even if measurement errors reduce the precision of the indicators, at a minimum it will still hold true that prudential rules are less stringent in the lower end of the indicator range than in the rest of the sample. And if there is a link between prudential regulation and banking equity 
developments in the data, then the lower end of the distribution in a given BPR indicator should have fared differently in this respect. Indeed this kind of reasoning is confirmed by the fact that these lowest-quartile indicators are significant for the BPR indicators in columns 5, 6 and 8 in Table A6, and that the estimated coefficients have negative signs as expected. In other words, banks in countries that belong to the bottom quartile with respect to the strength of regulation in one of these three areas were left with lower banking equity values after the crisis, in line with the previous findings.

Table A6. Prudential Regulation and Bank Share Prices During Crisis Times

Robustness Check using a dummy for the bottom quartile of BPR indicators

\begin{tabular}{|c|c|c|c|c|c|c|c|c|c|c|c|}
\hline Dummy for bottom quartile in & 1 & 2 & 3 & 4 & 5 & 6 & 7 & 8 & AVG & SD & MIN \\
\hline Capital Requirements & $\begin{array}{c}-0.14 \\
(0.12)\end{array}$ & & & & & & & & & & \\
\hline $\begin{array}{l}\text { Liquidity/ Diversification } \\
\text { Requirements }\end{array}$ & & $\begin{array}{r}-0.08 \\
(0.13)\end{array}$ & & & & & & & & & \\
\hline $\begin{array}{l}\text { Accounting/Provisioning } \\
\text { Requirements }\end{array}$ & & & $\begin{array}{r}-0.12 \\
(0.08)\end{array}$ & & & & & & & & \\
\hline $\begin{array}{l}\text { Ext. Auditing/ Information } \\
\text { Disclosure }\end{array}$ & & & & $\begin{array}{r}0.01 \\
(0.08)\end{array}$ & & & & & & & \\
\hline Entry/ Ownership & & & & & $\begin{array}{l}-0.20 \text { *** } \\
(0.05)\end{array}$ & & & & & & \\
\hline Exit/ Disciplining Rules & & & & & & $\begin{array}{l}0.05 \text { ** } \\
(0.02)\end{array}$ & & & & & \\
\hline Depositor Protection & & & & & & & $\begin{array}{l}-0.22 \text { *** } \\
(0.08)\end{array}$ & & & & \\
\hline Strength of Supervisor & & & & & & & & $\begin{array}{l}-0.17^{\star \star \star} \\
(0.05)\end{array}$ & & & \\
\hline Average of Area Indicators & & & & & & & & & $\begin{array}{l}-0.16^{\star *} \\
(0.06)\end{array}$ & & \\
\hline $\begin{array}{l}\text { Standard Deviation of Area } \\
\text { Indicators }\end{array}$ & & & & & & & & & & $\begin{array}{r}0.15 \\
(0.10)\end{array}$ & \\
\hline Minimum of Area Indicators & & & & & & & & & & & $\begin{array}{r}0.03 \\
(0.07)\end{array}$ \\
\hline $\begin{array}{l}\text { Share Price Development in } \\
\text { Non-Financials }\end{array}$ & $\begin{array}{l}0.766^{\star *} \\
(0.28)\end{array}$ & $\begin{array}{c}0.53^{*} \\
(0.28)\end{array}$ & $\begin{array}{l}0.73^{\star \star \star *} \\
(0.26)\end{array}$ & $\begin{array}{l}0.66 \text { ** } \\
(0.25)\end{array}$ & $\begin{array}{l}0.655^{* *} \\
(0.24)\end{array}$ & $\begin{array}{l}0.57^{\star \star} \\
(0.21)\end{array}$ & $\begin{array}{l}0.78^{* \star \star} \\
(0.27)\end{array}$ & $\begin{array}{l}0.58 \text { *** } \\
(0.20)\end{array}$ & $\begin{array}{l}0.699^{\star \star \star} \\
(0.14)\end{array}$ & $\begin{array}{l}0.522^{*} \\
(0.29)\end{array}$ & $\begin{array}{l}0.688^{* * \star} \\
(0.24)\end{array}$ \\
\hline Observations & 322 & 322 & 322 & 322 & 322 & 322 & 322 & 322 & 322 & 322 & 322 \\
\hline R-squared & 0.07 & 0.07 & 0.09 & 0.06 & 0.09 & 0.11 & 0.09 & 0.09 & 0.08 & 0.10 & 0.06 \\
\hline
\end{tabular}

\section{A4. Additional information for Section 4}

\section{Robustness check of the results presented in Table 7}

24. In order to test the robustness of the results obtained in Table 7 to changes in the estimation method, two alternative specifications have been estimated on net interest margins. The specification in Table A7 is similar to the preferred specification of Table 7 except that it allows for panel-specific (as opposed to a common) autocorrelation processes, while the specification in Table A8 relies on ordinary least squares rather than Prais-Winsten estimates, but still with panel-corrected standard errors that account 
for panel-level heteroscedasticity of standard errors. The results are very similar to the main results presented in Table 7, and thus confirm the previous findings.

Table A7. Prudential Regulation and Competition in Banking - Robustness Checks I

\begin{tabular}{|c|c|c|c|c|c|c|c|c|c|c|c|}
\hline & 1 & 2 & 3 & 4 & 5 & 6 & 7 & 8 & AVG & SD & $\mathrm{MIN}$ \\
\hline Capital Requirements & $\begin{array}{l}-0.01 \\
(0.02)\end{array}$ & & & & & & & & & & \\
\hline $\begin{array}{l}\text { Liquidity/ Diversification } \\
\text { Requirements }\end{array}$ & & $\begin{array}{r}0.00 \\
(0.00)\end{array}$ & & & & & & & & & \\
\hline $\begin{array}{l}\text { Accounting/Provisioning } \\
\text { Requirements }\end{array}$ & & & $\begin{array}{l}-0.01 \\
(0.01)\end{array}$ & & & & & & & & \\
\hline $\begin{array}{l}\text { Ext. Auditing/ Information } \\
\text { Disclosure }\end{array}$ & & & & $\begin{array}{r}0.06 \\
(0.04)\end{array}$ & & & & & & & \\
\hline Entry/ Ownership & & & & & $\begin{array}{l}\mathbf{0 . 1 2} \\
(0.01)\end{array}$ & & & & & & \\
\hline Exit/ Disciplining Rules & & & & & & $\begin{array}{l}-0.05^{* * *} \\
(0.01)\end{array}$ & & & & & \\
\hline Depositor Protection & & & & & & & $\begin{array}{r}0.00 \\
(0.00)\end{array}$ & & & & \\
\hline Strength of Supervisor & & & & & & & & $\begin{array}{l}-0.10^{\star \star \star} \\
(0.02)\end{array}$ & & & \\
\hline $\begin{array}{l}\text { Normalised Statistical } \\
\text { Measures }\end{array}$ & & & & & & & & & $\begin{array}{l}-0.06^{\star \star \star} \\
(0.02)\end{array}$ & $\begin{array}{l}\mathbf{0 . 1 2} \\
(0.06)\end{array}$ & $\begin{array}{l}-0.04 \text { *ᄎ } \\
(0.02)\end{array}$ \\
\hline Bank-level control variable & & & & & & & & & & & \\
\hline Equity / lagged total assets & $\begin{array}{r}0.08 \\
(2.50)\end{array}$ & $\begin{array}{r}0.33 \\
(2.17)\end{array}$ & $\begin{array}{r}0.14 \\
(1.24)\end{array}$ & $\begin{array}{r}0.20 \\
(2.71)\end{array}$ & $\begin{array}{r}1.48 \\
(1.96)\end{array}$ & $\begin{array}{r}2.67 \\
(2.14)\end{array}$ & $\begin{array}{r}0.21 \\
(1.81)\end{array}$ & $\begin{array}{l}1.67^{\star \star \star \star} \\
(0.35)\end{array}$ & $\begin{array}{r}0.69 \\
(1.98)\end{array}$ & $\begin{array}{r}-0.21 \\
(2.25)\end{array}$ & $\begin{array}{r}-0.16 \\
(1.98)\end{array}$ \\
\hline Loans / total assets & $\begin{array}{r}-0.54 \\
(1.00)\end{array}$ & $\begin{array}{r}-0.46 \\
(0.62)\end{array}$ & $\begin{array}{r}-0.49 \\
(0.72)\end{array}$ & $\begin{array}{r}-1.03 \\
(0.98)\end{array}$ & $\begin{array}{r}-0.31 \\
(0.58)\end{array}$ & $\begin{array}{l}-1.12 \text { * } \\
(0.68)\end{array}$ & $\begin{array}{r}-0.50 \\
(0.68)\end{array}$ & $\begin{array}{l}-0.14 \\
(0.29)\end{array}$ & $\begin{array}{r}-0.48 \\
(0.67)\end{array}$ & $\begin{array}{r}-0.61 \\
(0.77)\end{array}$ & $\begin{array}{l}-0.51 \\
(0.73)\end{array}$ \\
\hline $\begin{array}{l}\text { Non-interest earning assets/ } \\
\text { total assets }\end{array}$ & $\begin{array}{r}1.53 \\
(2.45)\end{array}$ & $\begin{array}{r}2.20 \\
(2.31)\end{array}$ & $\begin{array}{r}2.19 \\
(2.28)\end{array}$ & $\begin{array}{r}1.91 \\
(2.45)\end{array}$ & $\begin{array}{r}1.83 \\
(2.02)\end{array}$ & $\begin{array}{r}0.55 \\
(2.47)\end{array}$ & $\begin{array}{r}1.91 \\
(2.15)\end{array}$ & $\begin{array}{l}5.11^{\star \star \star} \\
(0.31)\end{array}$ & $\begin{array}{r}2.32 \\
(2.35)\end{array}$ & $\begin{array}{r}0.76 \\
(2.24)\end{array}$ & $\begin{array}{r}1.54 \\
(1.72)\end{array}$ \\
\hline $\begin{array}{l}\text { Customer and short term } \\
\text { funding/total assets }\end{array}$ & $\begin{array}{l}1.40^{\star \star \star} \\
(0.18)\end{array}$ & $\begin{array}{l}1.42^{\text {***}} \\
(0.11)\end{array}$ & 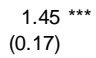 & 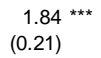 & $\begin{array}{l}1.56 \text { *** } \\
(0.13)^{*}\end{array}$ & $\begin{array}{l}1.31^{\text {***}} \\
(0.06)\end{array}$ & $\begin{array}{l}1.42^{\star \star \star} \\
(0.08)\end{array}$ & $\begin{array}{l}1.911^{\star \star \star} \\
(0.23)\end{array}$ & $\begin{array}{l}1.46^{\star \star \star} \\
(0.1)\end{array}$ & $\begin{array}{l}1.27^{\text {** }} \\
(0.11)\end{array}$ & $\begin{array}{l}1.26^{\text {***}} \\
(0.05)\end{array}$ \\
\hline Overhead / total assets & $\begin{array}{r}-0.99 \\
(1.73) \\
\end{array}$ & $\begin{array}{r}-0.51 \\
(0.93) \\
\end{array}$ & $\begin{array}{r}-0.60 \\
(1.22)\end{array}$ & $\begin{array}{r}-0.08 \\
(1.02) \\
\end{array}$ & $\begin{array}{r}-0.58 \\
(0.55)\end{array}$ & $\begin{array}{l}-1.53^{* *} \\
(0.77)\end{array}$ & $\begin{array}{r}-0.67 \\
(0.94) \\
\end{array}$ & $\begin{array}{r}1.21 \\
(0.84)\end{array}$ & $\begin{array}{r}-0.59 \\
(1.04)\end{array}$ & $\begin{array}{r}-1.43 \\
(1.35)\end{array}$ & $\begin{array}{r}-1.12 \\
(1.23)\end{array}$ \\
\hline \multicolumn{12}{|c|}{ Macroeconomic Control Variables } \\
\hline GDP per capita & $\begin{array}{r}0.29 \\
(1.03)\end{array}$ & $\begin{array}{r}0.32 \\
(0.94)\end{array}$ & $\begin{array}{r}0.25 \\
(1.09)\end{array}$ & $\begin{array}{r}0.75 \\
(1.07)\end{array}$ & $\begin{array}{r}0.61 \\
(0.74)\end{array}$ & $\begin{array}{r}0.15 \\
(0.88)\end{array}$ & $\begin{array}{r}0.33 \\
(0.93)\end{array}$ & $\begin{array}{r}0.86 \\
(0.72)\end{array}$ & $\begin{array}{r}0.20 \\
(0.92)\end{array}$ & $\begin{array}{r}0.23 \\
(0.94)\end{array}$ & $\begin{array}{r}0.13 \\
(1.01)\end{array}$ \\
\hline Grow th rate & $\begin{array}{l}14.17^{* \star *} \\
(4.02)\end{array}$ & $\begin{array}{l}13.70^{* \star \star} \\
(4.27)\end{array}$ & $\begin{array}{l}13.64 \text { *** } \\
(4.04)\end{array}$ & $\begin{array}{l}14.87^{\star \star \star} \\
(3.98)\end{array}$ & $\begin{array}{l}10.04^{\star * *} \\
(3.01)\end{array}$ & $\begin{array}{l}12.83^{\text {***}} \\
(3.57)\end{array}$ & $\begin{array}{l}13.90^{* \star \star} \\
(4.05)\end{array}$ & $\begin{array}{l}10.42^{* \star \star} \\
(2.11)\end{array}$ & $\begin{array}{l}13.23^{\text {***}} \\
(4.22)\end{array}$ & $\begin{array}{l}14.48^{\star \star \star} \\
(4.17)\end{array}$ & $\begin{array}{l}14.28^{* \star \star} \\
(3.78)\end{array}$ \\
\hline Inflation rate & $\begin{array}{l}11.05^{\star \star \star} \\
(3.57)\end{array}$ & $\begin{array}{l}11.52 \text { ***} \\
(1.42)\end{array}$ & $\begin{array}{l}11.80^{\star \star \star} \\
(1.56)\end{array}$ & $\begin{array}{l}12.20^{* \star \star} \\
(2.87)\end{array}$ & $\begin{array}{l}10.24^{* \star \star} \\
(2.34)\end{array}$ & $\begin{array}{l}13.18^{\text {***}} \\
(1.26)\end{array}$ & $\begin{array}{l}11.37^{\star \star \star} \\
(1.64)\end{array}$ & $\begin{array}{l}12.42^{\star \star \star} \\
(1.59)\end{array}$ & $\begin{array}{l}11.92^{\star \star \star} \\
(1.41)\end{array}$ & $\begin{array}{l}10.17^{\star \star \star} \\
(1.68)\end{array}$ & $\begin{array}{l}10.35^{\star \star \star} \\
(1.80)\end{array}$ \\
\hline Real interest rate & $\begin{array}{r}0.01 \\
(0.03)\end{array}$ & $\begin{array}{r}0.00 \\
(0.01)\end{array}$ & $\begin{array}{r}0.00 \\
(0.02)\end{array}$ & $\begin{array}{r}0.01 \\
(0.02)\end{array}$ & $\begin{array}{r}0.01 \\
(0.02)\end{array}$ & $\begin{array}{r}0.00 \\
(0.01)\end{array}$ & $\begin{array}{r}0.01 \\
(0.02)\end{array}$ & $\begin{array}{r}0.00 \\
(0.01)\end{array}$ & $\begin{array}{r}0.00 \\
(0.01)\end{array}$ & $\begin{array}{r}0.01 \\
(0.02)\end{array}$ & $\begin{array}{r}0.01 \\
(0.02)\end{array}$ \\
\hline Country Fixed Effects & yes & yes & yes & yes & yes & yes & yes & yes & yes & yes & yes \\
\hline Year Fixed Effects & yes & yes & yes & yes & yes & yes & yes & yes & yes & yes & yes \\
\hline Observations & 65 & 65 & 65 & 65 & 65 & 65 & 65 & 65 & 65 & 65 & 65 \\
\hline R-squared & 0.88 & 0.87 & 0.88 & 0.88 & 0.89 & 0.88 & 0.87 & 0.89 & 0.78 & 0.78 & 0.78 \\
\hline
\end{tabular}


Table A8. Prudential Regulation and Competition in Banking - Robustness Checks II

\begin{tabular}{|c|c|c|c|c|c|c|c|c|c|c|c|}
\hline & 1 & 2 & 3 & 4 & 5 & 6 & 7 & 8 & $A V G$ & SD & $\mathrm{MIN}$ \\
\hline Capital Requirements & $\begin{array}{l}-0.01 \\
(0.02)\end{array}$ & & & & & & & & & & \\
\hline $\begin{array}{l}\text { Liquidity/ Diversification } \\
\text { Requirements }\end{array}$ & & $\begin{array}{r}0.00 \\
(0.01)\end{array}$ & & & & & & & & & \\
\hline $\begin{array}{l}\text { Accounting/Provisioning } \\
\text { Requirements }\end{array}$ & & & $\begin{array}{l}-0.01 \\
(0.01)\end{array}$ & & & & & & & & \\
\hline $\begin{array}{l}\text { Ext. Auditing/Information } \\
\text { Disclosure }\end{array}$ & & & & $\begin{array}{r}0.02 \\
(0.03)\end{array}$ & & & & & & & \\
\hline Entry/ Ownership & & & & & $\begin{array}{l}\mathbf{0 . 1 1} 1^{\star \star \star} \\
(0.03)\end{array}$ & & & & & & \\
\hline Exit/ Disciplining Rules & & & & & & $\begin{array}{l}-0.03 \text { ** } \\
(0.02)\end{array}$ & & & & & \\
\hline Depositor Protection & & & & & & & $\begin{array}{r}0.01 \\
(0.02)\end{array}$ & & & & \\
\hline Strength of Supervisor & & & & & & & & $\begin{array}{l}-0.09 * * * \\
(0.02)\end{array}$ & & & \\
\hline $\begin{array}{l}\text { Normalised Statistical } \\
\text { Measures }\end{array}$ & & & & & & & & & $\begin{array}{l}-0.07^{\star \star \star} \\
(0.09)\end{array}$ & $\begin{array}{l}\mathbf{0 . 0 6} \\
(0.09)\end{array}$ & $\begin{array}{r}-0.04 \\
(0.04)\end{array}$ \\
\hline \multicolumn{12}{|l|}{ Bank-level control variables } \\
\hline Equity / lagged total assets & $\begin{array}{r}-1.20 \\
(1.62)\end{array}$ & $\begin{array}{r}-1.18 \\
(1.57)\end{array}$ & $\begin{array}{l}-1.38 \\
(1.64)\end{array}$ & $\begin{array}{r}-1.22 \\
(1.59)\end{array}$ & $\begin{array}{r}-1.31 \\
(1.50)\end{array}$ & $\begin{array}{r}-0.08 \\
(1.68)\end{array}$ & $\begin{array}{r}-1.13 \\
(1.59)\end{array}$ & $\begin{array}{r}-0.82 \\
(1.39)\end{array}$ & $\begin{array}{r}-1.10 \\
(1.59)\end{array}$ & $\begin{array}{r}-1.06 \\
(1.60)\end{array}$ & $\begin{array}{r}-1.16 \\
(1.58)\end{array}$ \\
\hline Loans / total assets & $\begin{array}{r}1.11 \\
(0.93)\end{array}$ & $\begin{array}{r}1.22 \\
(0.91)\end{array}$ & $\begin{array}{r}1.13 \\
(0.94)\end{array}$ & $\begin{array}{r}1.03 \\
(0.96)\end{array}$ & $\begin{array}{l}1.23 \\
(0.73)\end{array}$ & $\begin{array}{r}0.79 \\
(0.89)\end{array}$ & $\begin{array}{r}1.12 \\
(0.93)\end{array}$ & $\begin{array}{l}1.42^{*} \\
(0.76)\end{array}$ & $\begin{array}{r}1.15 \\
(0.91)\end{array}$ & $\begin{array}{r}1.12 \\
(0.93)\end{array}$ & $\begin{array}{r}1.15 \\
(0.91)\end{array}$ \\
\hline $\begin{array}{l}\text { Non-interest earning assets/ } \\
\text { total assets }\end{array}$ & $\begin{array}{l}6.67^{\star \star} \\
(2.87)\end{array}$ & $\begin{array}{l}6.90 \text { ** } \\
(2.86)\end{array}$ & $\begin{array}{l}6.95^{\text {** }} \\
(2.84)\end{array}$ & $\begin{array}{l}7.19^{* *} \\
(2.84)\end{array}$ & $\begin{array}{l}5.79^{* *} \\
(2.58)\end{array}$ & $\begin{array}{l}5.82^{* *} \\
(2.87)\end{array}$ & $\begin{array}{l}7.05^{\star \star} \\
(2.85)\end{array}$ & $\begin{array}{l}7.80^{\star \star \star} \\
(2.42)^{2}\end{array}$ & $\begin{array}{l}6.89^{\star \star} \\
(2.80)\end{array}$ & $\begin{array}{l}6.74^{\star \star} \\
(2.91)\end{array}$ & $\begin{array}{l}7.00 \text { ** } \\
(2.81)\end{array}$ \\
\hline $\begin{array}{l}\text { Customer and short term } \\
\text { funding/ total assets }\end{array}$ & $\begin{array}{l}1.13^{\text {** }} \\
(0.57)\end{array}$ & $\begin{array}{l}1.16^{\star \star} \\
(0.56)\end{array}$ & $\begin{array}{l}1.14^{\star \star} \\
(0.58)\end{array}$ & $\begin{array}{l}1.29 \text { ** } \\
(0.57)\end{array}$ & $\begin{array}{l}1.55^{\star \star \star \star} \\
(0.44)\end{array}$ & $\begin{array}{l}1.07^{*} \\
(0.56)\end{array}$ & $\begin{array}{l}1.10^{*} \\
(0.57)\end{array}$ & $\begin{array}{l}1.33^{\star \star \star} \\
(0.51)\end{array}$ & $\begin{array}{l}1.08 \text { * } \\
(0.58)\end{array}$ & $\begin{array}{l}1.07^{*} \\
(0.57)\end{array}$ & $\begin{array}{l}0.97^{*} \\
(0.57)\end{array}$ \\
\hline Overhead / total assets & $\begin{array}{r}2.74 \\
(2.40)\end{array}$ & $\begin{array}{r}3.17 \\
(2.45)\end{array}$ & $\begin{array}{r}3.14 \\
(2.45) \\
\end{array}$ & $\begin{array}{r}3.61 \\
(2.43)\end{array}$ & $\begin{array}{r}3.37 \\
(2.26)\end{array}$ & $\begin{array}{r}3.04 \\
(2.39) \\
\end{array}$ & $\begin{array}{r}3.33 \\
(2.47) \\
\end{array}$ & $\begin{array}{l}3.75 * \\
(2.00)\end{array}$ & $\begin{array}{r}3.07 \\
(2.32) \\
\end{array}$ & $\begin{array}{r}3.08 \\
(2.43) \\
\end{array}$ & $\begin{array}{r}2.91 \\
(2.35) \\
\end{array}$ \\
\hline \multicolumn{12}{|c|}{ Macroeconomic Control Variables } \\
\hline GDP per capita & $\begin{array}{r}0.60 \\
(0.58)\end{array}$ & $\begin{array}{r}0.71 \\
(0.52)\end{array}$ & $\begin{array}{r}0.61 \\
(0.59)\end{array}$ & $\begin{array}{c}0.88^{*} \\
(0.53)\end{array}$ & $\begin{array}{l}1.35^{\star \star} \\
(0.57)\end{array}$ & $\begin{array}{r}0.72 \\
(0.51)\end{array}$ & $\begin{array}{r}0.75 \\
(0.52)\end{array}$ & $\begin{array}{l}1.12 \text { ** } \\
(0.45)\end{array}$ & $\begin{array}{r}0.55 \\
(0.56)\end{array}$ & $\begin{array}{r}0.65 \\
(0.53)\end{array}$ & $\begin{array}{r}0.49 \\
(0.57)\end{array}$ \\
\hline Grow th rate & $\begin{array}{l}11.53^{\star \star \star} \\
(1.90)\end{array}$ & $\begin{array}{l}11.99^{\star \star \star} \\
(2.02)\end{array}$ & $\begin{array}{l}11.84^{\star \star \star} \\
(1.98)\end{array}$ & $\begin{array}{l}11.95^{\text {***}} \\
(2.03)\end{array}$ & $\begin{array}{l}9.91^{\star \star \star \star} \\
(1.58)\end{array}$ & $\begin{array}{l}12.01^{\star \star \star} \\
(1.86)\end{array}$ & $\begin{array}{l}11.46^{\star \star \star} \\
(2.18)\end{array}$ & $\begin{array}{l}10.89^{\star \star \star} \\
(1.52)\end{array}$ & $\begin{array}{l}11.766^{\star \star \star} \\
(1.93)\end{array}$ & $\begin{array}{l}11.83^{\star \star \star} \\
(1.96)\end{array}$ & $\begin{array}{l}11.74^{\star \star \star} \\
(1.93)\end{array}$ \\
\hline Inflation rate & $\begin{array}{l}7.79^{\star \star *} \\
(2.89)\end{array}$ & $\begin{array}{l}7.39^{\star \star \star} \\
(2.83)\end{array}$ & $\begin{array}{l}7.54^{\star \star \star} \\
(2.86)\end{array}$ & $\begin{array}{l}7.95^{\star \star \star *} \\
(3.01)\end{array}$ & $\begin{array}{c}5.28 \text { * } \\
(2.88)\end{array}$ & $\begin{array}{l}7.77^{\star \star \star} \\
(2.90)\end{array}$ & $\begin{array}{l}7.78^{\star \star \star} \\
(2.87)\end{array}$ & $\begin{array}{l}5.38 \text { ** } \\
(2.54)\end{array}$ & $\begin{array}{l}7.22 \text { ** } \\
(2.89)\end{array}$ & $\begin{array}{l}7.29 \text { ** } \\
(2.85)\end{array}$ & $\begin{array}{l}7.14 \text { ** } \\
(2.87)\end{array}$ \\
\hline Real interest rate & $\begin{array}{r}0.02 \\
(0.02)\end{array}$ & $\begin{array}{r}0.02 \\
(0.02)\end{array}$ & $\begin{array}{r}0.02 \\
(0.02)\end{array}$ & $\begin{array}{r}0.02 \\
(0.02)\end{array}$ & $\begin{array}{r}0.05 \\
(0.02)\end{array}$ & $\begin{array}{r}0.03 \\
(0.02)\end{array}$ & $\begin{array}{r}0.02 \\
(0.02)\end{array}$ & $\begin{array}{r}0.04 \\
(0.02)\end{array}$ & $\begin{array}{r}0.02 \\
(0.02) \\
(0.18)\end{array}$ & $\begin{array}{r}0.02 \\
(0.02) \\
(0.16)\end{array}$ & $\begin{array}{r}0.02 \\
(0.02) \\
(0.19)\end{array}$ \\
\hline Country Fixed Effects & yes & yes & yes & yes & yes & yes & yes & yes & yes & yes & yes \\
\hline Year Fixed Effects & yes & yes & yes & yes & yes & yes & yes & yes & yes & yes & yes \\
\hline Observations & 65 & 65 & 65 & 65 & 65 & 65 & 65 & 65 & 65 & 65 & 65 \\
\hline R-squared & 0.78 & 0.78 & 0.78 & 0.78 & 0.82 & 0.79 & 0.78 & 0.82 & 0.78 & 0.78 & 0.78 \\
\hline
\end{tabular}

Note: Standard errors in parentheses. ${ }^{* * *},{ }^{* *},{ }^{*}$ indicate statistical significance at the 1,5 and $10 \%$ levels, respectively.

\section{Competition-adverse versus competition-friendly rules}

25. In section 4.1.3 individual rules were split into those that are potentially competition-adverse, and those that are either competition-enhancing or competition-neutral (the latter two categories are classified as "competition-friendly"). This split was solely based on judgement, with the exact classification of all questions being reported above in this Annex. For the overwhelming number of questions, classification as competition-adverse or competition-friendly was straightforward and should hence be largely uncontroversial. ${ }^{63}$

26. Calculating the proportion of competition-adverse regulations for each area of prudential banking regulation shows a very uneven incidence of competition-adverse regulation across different areas of banking regulation (Figure A11). Whereas for half of the sub-sectors all individual regulations are

63. Information from the Financial Stability Assessment Program on compliance with recommendations by international standard-setters was not divided by their potential impact on competition. Not only would it be extremely difficult to classify already aggregated information in the above way, but results of such an exercise would necessarily appear arbitrary and hence bound to be controversial. 
classified as competition-friendly, competition-adverse prudential regulation is especially common when it comes to "Entry Rules and Ownership Structures". Competition-adverse regulation can also be found in the areas of "Liquidity and Diversification Requirements", "External Auditing and Information Disclosure Requirements", and "Depositor Protection", although to a much lower extent.

Figure A11. Average Share of Competition-Adverse Regulation by Area

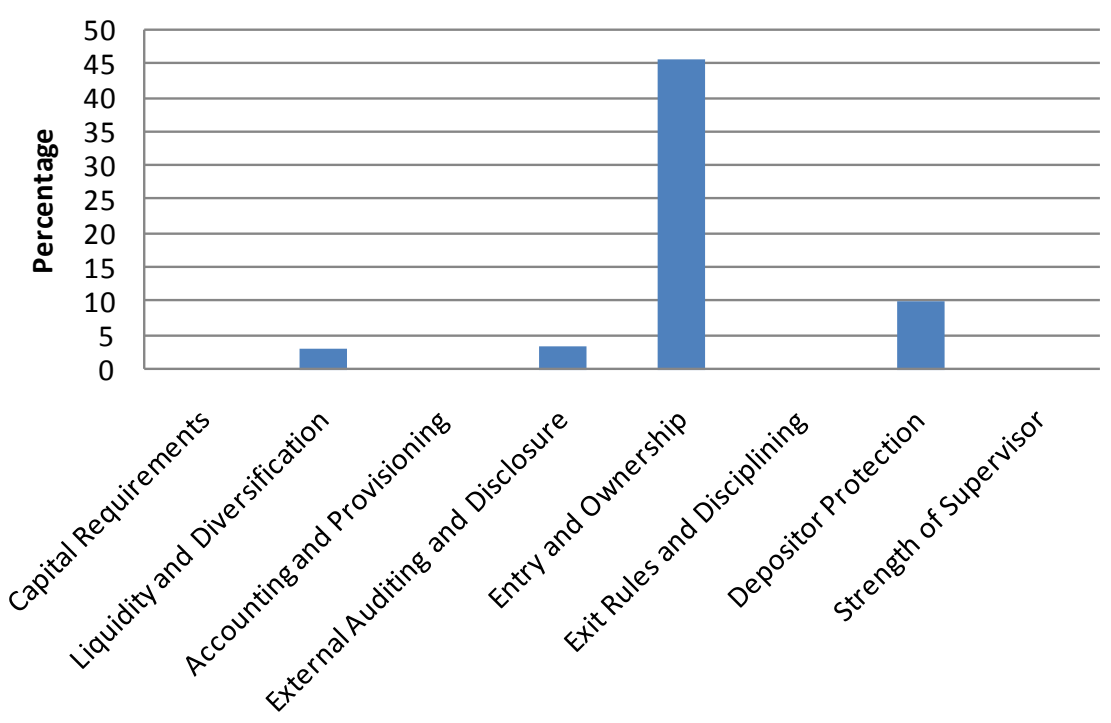

27. Reliance on competition-adverse regulation differs also markedly across countries, with AC and EE5 countries, and especially China, India and Indonesia, relying somewhat more on competition-adverse regulation than their OECD counterparts (see Figure A12 below). This concords with the finding that, on average, AC and EE5 countries rely somewhat more on entry and ownership regulation than their OECD counterparts. Within the OECD, Canada, the Czech Republic, Greece, Hungary, Korea, Mexico, Poland, Portugal and Turkey show a clear above-average reliance on competition-adverse regulation.

Figure A12. Competition-Adverse Prudential Regulation in the Banking Sector by Country Strength of Competition-Adverse Financial Stability Oriented Regulation

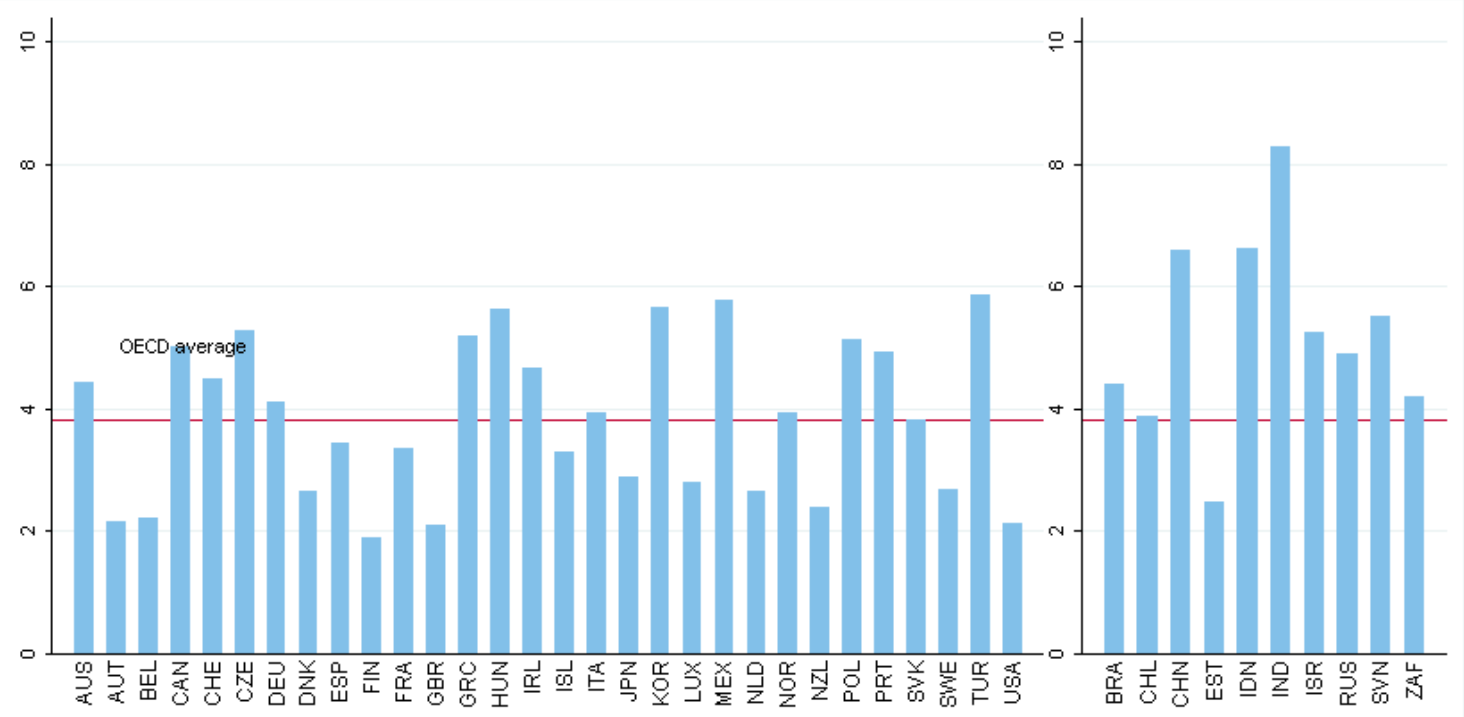


ECO/WKP(2009)76

\section{WORKING PAPERS}

The full series of Economics Department Working Papers can be consulted at www.oecd.org/eco/working_papers/

734. Keeping Slovenian Public Finances on a Sustainable Path (October 2009) Pierre Beynet and Willi Leibfritz

733. Pedal to the metal: Structural reforms to boost long-term growth in Mexico and spur recovery from the crisis

(October 2009) David Haugh and Agustin Redonda

732. Achieving higher performance: Enhancing spending efficiency in health and education in Mexico (October 2009) Cyrille Schwellnus

731. Russia's long and winding road to a more efficient and resilient banking sector (October 2009) Geoff Barnard

730. How do institutions affect structural unemployment in times of crises? (October 2009) Davide Furceri and Annabelle Mourougane

729. Understanding the world trade collapse

(October 2009) Calista Cheung and Stéphanie Guichard

728. Estonia and euro adoption: Small country challenges of joining EMU

(October 2009) Zuzana Brixiova, Margaret H. Morgan and Andreas Wörgötter

727 Towards better schools and more equal opportunities for learning in Italy (June 2009) Romina Boarini

726. Iceland: Challenging Times for Monetary and Fiscal Policies (August 2009) Andrea De Michelis

725. Iceland: The Financial and Economic Crisis (August 2009) David Carey

724. The role of transparency in the conduct of monetary policy (September 2009) Makoto Minegishi and Boris Cournède

723. Raising education outcomes in Greece (September 2009) Vassiliki Koutsogeorgopoulou

722. Improving the performance of the public health care system in Greece (September 2009) Charalampos Economou and Claude Giorno

721. Is there a case for price-level targeting?

(August 2009) Boris Cournède and Diego Moccero

720. The challenge of restoring French competitiveness (August 2009) Rafal Kierzenkowski 
719. Improving the functioning of the Slovenian labour market (August 2009) Isabell Koske

718. What drives sovereign risk premiums? An analysis of recent evidence from the Euro Area (July 2009) David Haugh, Patrice Ollivaud, and David Turner

717. The English National Health Service: an economic health check (July 2009) Peter Smith and Maria Goddard

716. Financial stability in the United Kingdom: Banking on prudence (July 2009) Philip Davis

715. Economic growth and the role of taxation- disaggregate data (July 2009) Gareth D. Myles

714. Economic growth and the role of taxation-Aggregate data (July 2009) Gareth D. Myles

713. Economic growth and the role of taxation - Theory (July 2009) Gareth D. Myles

712. The effectiveness of education and health spending among Brazilian municipalities (July 2009) Luiz de Mello and Mauro Pisu

711. The bank lending channel of monetary transmission in Brazil: A VECM approach (July 2009) Luiz de Mello and Mauro Pisu

710. How does decentralised minimum-wage setting affect unemployment and informality? The case of Indonesia (July 2009) Margherita Comola and Luiz de Mello

709. Intergenerational social mobility in European OECD countries (July 2009) Orsetta Causa, Sophie Dantan and Åsa Johansson

708. Equity in student achievement across OECD countries: an investigation of the role of policies (July 2009) Orsetta Causa and Catherine Chapuis

707. Intergenerational social mobility (July 2009) Orsetta Causa and Åsa Johansson

706. Taxes or grants: what revenue source for sub-central governments? (July 2009) Hansjörg Blöchliger and Oliver Petzold

705. The spending power of sub-central governments: a pilot study (July 2009) Steffen Bach, Hansjörg Blöchliger and Dominik Wallau

704. Price and volume elasticities of Brazilian foreign trade: A profit function approach (July 2009) Luiz de Mello and Mauro Pisu 